Katedra blízkovýchodních studií

Filozofická fakulta

Západočeská univerzita v PIzni

https://doi.org/10.24132/ZCU.2018.07156

2018

\section{Historie a kultura asijských zemí}




\section{Historie a kultura asijských zemí}

Editor:

Lukáš Pecha

Vydání publikace bylo schváleno Vědeckou redakcí Západočeské univerzity v Plzni.

Odborní recenzenti:

prof. PhDr. Ladislav Bareš, CSc.

doc. Jan Dušek, Ph.D.

Typografická úprava:

Jakub Pokorný

Grafický návrh obálky:

Iveta Hostašová

Vydala:

Západočeská univerzita v Plzni

P.0.Box 314, Univerzitní 8, 30614 Plzeň

První vydání, 126 stran

Pořadové číslo: 2263, ediční číslo: 55-054-17

Plzeň 2018

https://doi.org/10.24132/ZCU.2018.07156

ISBN 978-80-261-0715-6

(C) Autoři

Západočeská univerzita v Plzni 


\section{Předmluva}

Tato publikace si klade za cíl představit historický vývoj civilisací na rozsáhlém teritoriu, které zahrnuje především oblast Blízkého východu a rovněž některá území nacházející se ve střední a jižní Asii. Odborníci z různých vědeckých a vědecko-pedagogických pracovišt, kteří se dlouhodobě zabývají studiem kultury jednotlivých regionů na tomto teritoriu, v této knize předkládají výsledky svých dílčích projektů, které jsou věnovány rozličným aspektům kulturního vívoje v dlouhém časovém úseku od starověku až do současnosti, príčemž hlavní pozornost je věnována vývoji asijských civilisací v období starověku.

Texty jednotlivých př́spěvků byly presentovány na XVI. ročníku kolokvia Orientalia Antiqua Nova, které uspořádala Katedra blízkovýchodních studií Filosofické fakulty Západočeské university v Plzni v dubnu 2016. Věríme, že předkládaná publikace bude užitečná pro širokou zainteresovanou veřejnost, podnítí další spolupráci při výzkumu starých civilisací na asijském kontinentu a obohatí naše znalosti o tomto regionu.

Lukáš Pecha

editor 


\section{Obsah}

Předmluva …….............................................................. 3

Pavel Král

Osídlení okolo Mosulu v rané době bronzové ................................ 5

Kateřina Šašková

Asyrský král Asarhaddon v péči dvorních lékařů ......................... 24

David Rafael Moulis

Základové oběti v Kanaánu - olejové lampy s miskou

a rituální pohřbívání oslů

Katarína Šomodiová

Mandejci včera a dnes

Michal Habaj

Skýthové v Hérodotově mentálním světě: několik příkladů

konstrukce Dějin

Simona Levá Jandová

Motiv kmene Kuravů v tamilském žánru kuravaňdži

86

Tomáš Retka

Jazyková politika současné Tádžické republiky

v historicko-politických souvislostech

Summary 


\section{Osídlení okolo Mosulu v rané době bronzové}

\section{Úvod}

Studium struktury osídlení a jejích proměn nám umožňuje pozorovat některé projevy sociálních a ekonomických transformací. Raná doba bronzová je období, které můžeme zjednodušeně chápat jako 3. tisíciletí př. Kr. Existuje několik možných podrobnějších chronologických dělení, ale $v$ této studii budeme rozlišovat pouze hlavní tři epochy - kulturu ninivskou 5 (3000-2500 př. Kr.) a dobu akkadské (2350-2150 př. Kr.) a urské (2100-2000 př. Kr.) řriše. Poslední dvě zmíněné fáze bývají z hlediska keramického vývoje označované jako pozdní 3. tisíciletí.

Region, který nás zde nejvíce zajímá, má rozměry asi 60 x 60 km, a město Mosul je približně ve středu této oblasti. Nejvýznamnějším dlouhodobě osídleným místem, které vykazuje taktéž stopy lidské prítomnosti z rané doby bronzové, je Ninive, dnes zcela obklopené městskou zástavbou Mosulu.

Tato studie se opírá nejen o prameny písemné, ale zvláště o ty archeologické, které jsou pro nás nesmírně informativní. Průzkumy krajiny v okolních oblastech (severní Džazíra, okolí Arbílu) odhalily určité tendence sídelního vývoje. Jelikož koncem 3. tisíciletí př. Kr. začaly v severní Mezopotámii vznikat první státní útvary, může nám studium krajiny poodhalit pozadí některých transformačních procesů, které doprovázely formování těchto raných států.

\footnotetext{
${ }^{1}$ Wilkinson - Tucker 1995, 48.
} 


\section{Struktura osídlení v okolních regionech}

Výzkum severní Džazíry odhalil rozvoj sídelní hierarchie, kdy danému regionu dominovala Tell al-Hawa coby hlavní centru. Dále tam byla také menší sekundární centra a nejnižší úroveň představovaly služebné osady, které tvořily jakési satelity svých center. Týkalo se to především doby ninivské 5 . V pozdním 3. tisíciletí př. Kr. došlo k úbytku počtu satelitních sídlišt kolem hlavního centra, což bylo nejspiš způsobeno přesunem tamních obyvatel do střediskové obce. ${ }^{2}$ Rozloha Tell al-Hawy tehdy dosáhla svého maxima (14-80 ha). ${ }^{3}$

Rozvoj měst byl pro období 2600-2000 př. Kr. zaznamenán také v okolí Arbílu. Jedno z největších center tohoto regionu dnes skrývá Tell Baqrta. Samotný pahorek má sice jen 4 ha, ale je obklopen dolním městem, které zvyšuje rozlohu na 80 ha. To je srovnatelné s dalšími urbánními centry severní Mezopotámie, jako jsou např. Hamoukar (98 ha), Tell Lejlán (90 ha) či Tell Brák (70 ha). V pláni okolo Arbílu byla i další rozsáhlá sídliště. Komplex několika těsně sousedících lokalit nedaleko Qasr Šemamoku má asi 55 ha. Dủležitý byl také samotný Arbíl, který je z konce 3. tisíciletí znám z písemných pramenů jako město Urbilum. Toto toponymum se vyskytuje $v$ textech $z$ Ebly z akkadského období a poté v nápisech vládců III. dynastie z Uru. ${ }^{4}$

\section{Urbanismus v severní Mezopotámii}

V celé severní Mezopotámii došlo v době 2600-2000 př. Kr. k výraznému urbánnímu rozvoji. Ve městech žilo 10-15 tisíc obyvatel, nacházely se tam nejen residenční čtvrti, ale rovněž chrámové a palácové komplexy. V okolní krajině pak byly menší osady, většina obyvatel však žila ve městech. ${ }^{5} \mathrm{Na}$ konci milénia nastal určitý zlom, který prinesl transformaci struktury osídlení. Vzrostl počet drobných vesnic, některá města byla opuštěna, prípadně se jejich rozloha

\footnotetext{
2 Wilkinson 1990, 56-57; Wilkinson - Tucker 1995, 48-57.

3 Ball - Wilkinson 1989-90, 10.

4 Ur-De Jong - Giraud - Osborne - MacGinnis 2013, 97-99.

5 Ur 2013, 31.
} 
zmenšila. ${ }^{6}$ Na prǐčiny těchto změn existují rozdílné názory. ${ }^{7}$

\section{Metodologie zkoumání krajiny}

Tato studie vznikla jako jeden z výstupů výzkumu, který se zabýval studiem krajiny severního Iráku. ${ }^{8}$ Na mapách publikace Atlas of Archaeological Sites in Iraq (Directorate General of Antiquites 1976) nalezneme vyznačeny některé lokality, které jsme s to datovat, zvláště díky katalogu Archaeological Sites in Iraq (Directorate General of Antiquites 1970). Pro dobu ninivskou 5 v námi studované oblasti známe 16 toponym a pro pozdní 3. tisíciletí př. Kr. 9 místních jmen. Georeferencováním map s lokalitami v programu ArcGIS získáme přehled 0 jejich prostorovém uspořádání v krajině (Přiloha 1 a 2).

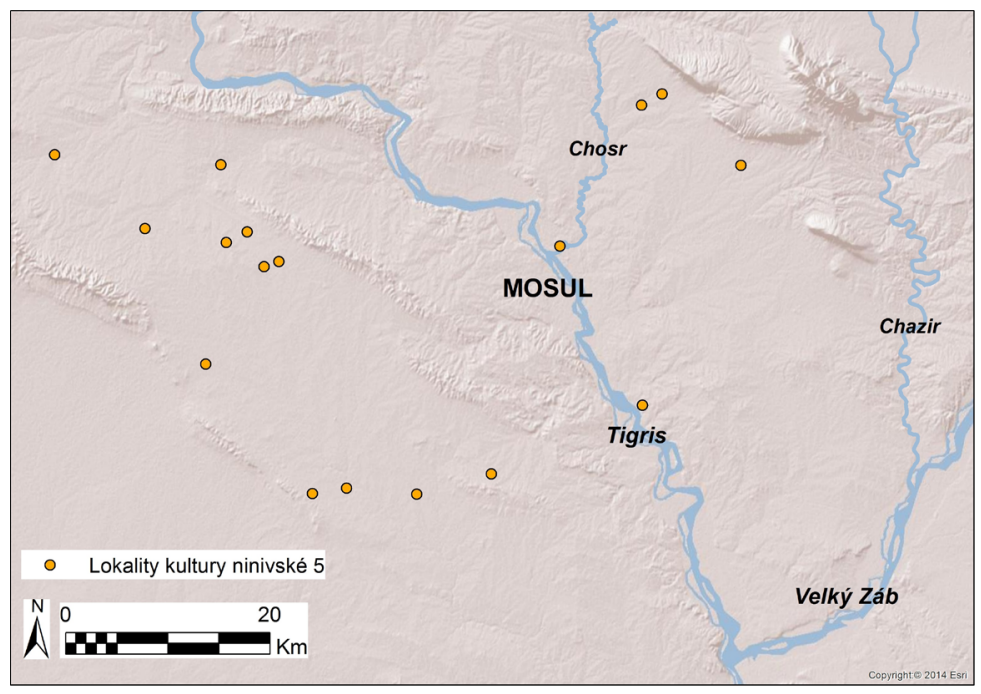

Přiloha 1. Prostorové rozmístění lokalit doby ninivské 5

\footnotetext{
${ }^{6}$ Ur 2012, 25.

7 Hlavní teorie týkající se úpadku urbánních center nalezneme v: Weiss a kol. 1993, Matthews 1997, Ristvet - Weiss 2000, Ur 2012.

${ }^{8}$ Hlavní výstup tohoto výzkumu je popsán v doktorské práci Krajina v zázemíasyrských metropolí(Král 2016).
} 


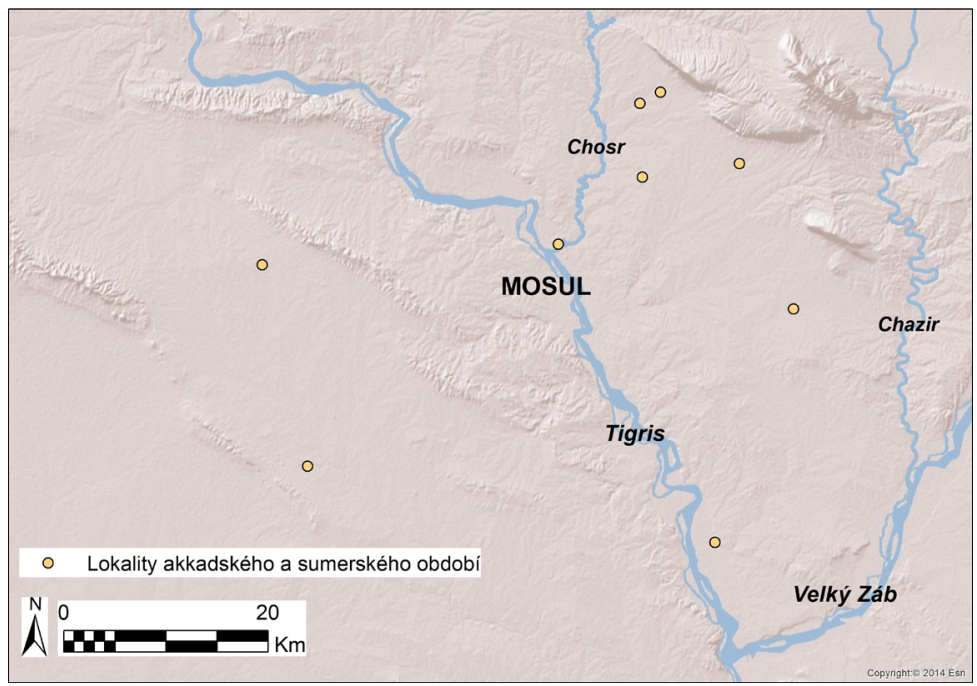

Příloha 2. Prostorové rozmístění lokalit pozdního 3. tisíciletí př. Kr.

Většinu z těchto lokalit dokážeme ztotožnit s konkrétními relikty lidské sídelní aktivity, které jsou patrné na satelitních snímcích CORONA. Na nich vidíme lokality, které se projevují skvrnitostí způsobenou nestejnou schopností držet vodu. Mohou za to zvláště zerodované hliněné cihly. Jsme tak s to identifikovat nejen sídlištní pahorky, ale také rovinná sídliště, téměř nepatrná v terénu. ${ }^{9} \mathrm{Na}$ snímcích CORONA vidíme i pozůstatky sítě komunikací. Jedná se o úvozy široké až $100 \mathrm{~m}$ a hluboké až $2 \mathrm{~m}$. Díky vyšší vlhkosti v hlubších částech se projevují coby tmavé linie. Hlavní centra, ale i menší lokality dosahující 5 ha a někdy i méně, mají kolem sebe často radiální systém úvozů, které sahají 3-5 km daleko. Část z nich vede do polí a lze je chápat jako důsledek přesunů zemědělců na jejich pole a pastevců k pastvinám. ${ }^{10}$ Pro telly rané doby bronzové jsou charakteristické velmi široké cesty, které se nacházejí nejčastěji kolem centrálních lokalit a spojují je s jejich satelitními osadami. Vypovídají tak o ekonomických vazbách.

\footnotetext{
${ }^{9}$ Ur 2003, 105.

10 Ur 2003, 102-103; Ur 2013, 31.
} 
V některých případech vytváří celou regionální sít komunikací. ${ }^{11}$

\section{Hlavní sídliště a jejich okolí}

\section{Ninive}

Z celkového korpusu klínopisných textů jich jen velmi malá část pochází ze severní Mezopotámie z doby 3. tisíciletí pr. Kr. Informativní jsou pro nás ale i některé texty pocházející z jiných regionů, zvláště z centra urské řǐše. 0 struktuře osídlení v okolí Mosulu písemné prameny příliš nevypovídají. Zdá se však být patrné, že Ninive bylo nejvýznamnějším střediskem tohoto regionu. Na sérii vrstev pravěkých keramických kultur (hassúnská až ninivská 5) se nacházejí stopy osídlení z doby akkadské. ${ }^{12} \mathrm{Na}$ jejich základě bohužel nelze stanovit, zda Ninive patřilo do akkadské řiše tak jako Aššur či Tell Brák. V jednom staroasyrském nápisu Šamší-Adada I. se píše, že akkadský vládce Man-ištúšu nechal v Ninive postavit chrám. Tato informace je sice obecně prijímána jako pravdivá, ale některé indicie naznačují, že tomu tak být nemuselo. ${ }^{13}$ V akkadské době byly postaveny hradby chránící osídlení na vrcholku tellu, které zabíralo plochu asi 40 ha. 0 existenci dolního města nemáme žádné informace, přestože $v$ době ninivské 5 byl osídlen nejen samotný tell, ale také část jeho severního úpatí. ${ }^{14} \mathrm{~V}$ období III. dynastie z Uru bylo Ninive nejspíše centrem samostatného státního útvaru. Neplatilo poplatky zvané „gu-ún ma-da“, které ale Uru odváděli obyvatelé Aššuru či Urbilum. ${ }^{15}$ Na základě kontextu ojedinělých zmínek o Ninive v textech z urského státu se zdá, že Ninive ovládali Churrité. ${ }^{16}$ Jistý Tiš-Atal, titulovaný jako „muž z Ninive”, prǐijel do urské říše na diplomatickou návštěvu. Jednal s jedním z nejvyšších představitelů urského státu, což svědčí o jeho významnosti. ${ }^{17}$

\footnotetext{
11 Ur 2003, 107-111.

12 Stronach 1994, 85; Reade 2000, 395-396.

13 Westenholz 2004, 9-14; Král 2012, 13-14.

14 Stronach 1994, 92-94.

15 Steinkeller 1991, 28; Westenholz, Sallaberger 1999, 196-199.

16 Westenholz 2004, 10.

17 Whiting 1976, 174-177; Král 2012, 23-25.
} 
Přestože bylo Ninive nejdůležitějším centrem celého regionu, pozdější zásahy do krajiny odstranily stopy, které by nám objasnily strukturu osídlení v okolí města. Nejsou patrné žádné služebné osady a nepozorujeme ani výrazný radiální systém komunikací, který bychom mohli předpokládat. K městu sice směřuji cesty, ale zdá se, že vedou k pozdějším branám novoasyrského opevnění. ${ }^{18}$ Město po celou dobu své existence nejspíše těžilo ze své pozice na křižovatce dálkových cest. Jednou z nich byl Tigris, který vede od severu na jih, druhá cesta vedla v ose východ-západ a využívala brod, který byl u Ninive. ${ }^{19}$

\section{Tell Billa}

Druhým důležitým toponymem, které lze lokalizovat v okolí Mosulu, je novoasyrské město Šibaniba, dnešní Tell Billa. V klínopisných textech se však vyskytuje často i v jiných podobách. Starobabylónské texty z Mari ho uvádějí jako Šibanum, urské texty jako Šimánum a v písemných pramenech z dob vládců Akkadu ho nalezneme ve formě Asimánum. Sídlo stejného či velmi podobného jména však Ize hledat i někde na horním toku Tigridu. ${ }^{20}$ To nám pưsobí určité problémy, protože dané toponymum se vyskytuje v královských nápisech jako cíl některých válečných výprav a není jasné, zda jde o dnešní Tell Billu, či nikoliv. ${ }^{21}$

Na základě archeologických pramenů je však patrné, že Tell Billa byla dalším hlavním střediskem regionu. Její význam ale předpokládáme spíše na lokální úrovni. Sídlištní pahorek má rozlohu bezmála 30 ha a po Kujundžiku (34 ha) je druhým největším tellem v regionu. ${ }^{22}$ Kolem lokality je také velmi výrazný radiální systém komunikací (Přiloha 3). Úvozové cesty jsou dlouhé 3-4 km, některé vedou k menším lokalitám, které Ize snad interpretovat jako služebné osady. Severně od tellu se zvedají hřebeny Džebel Bášiqa, což je nejspišse důvod, proč na tuto

\footnotetext{
18 Altaweel 2003, 223, 227.

19 Stronach 1994, 86.

20 Westenholz 2004, 10.

21 Král 2012, 9, 19-25.

22 Král 2016, 310, 314.
} 


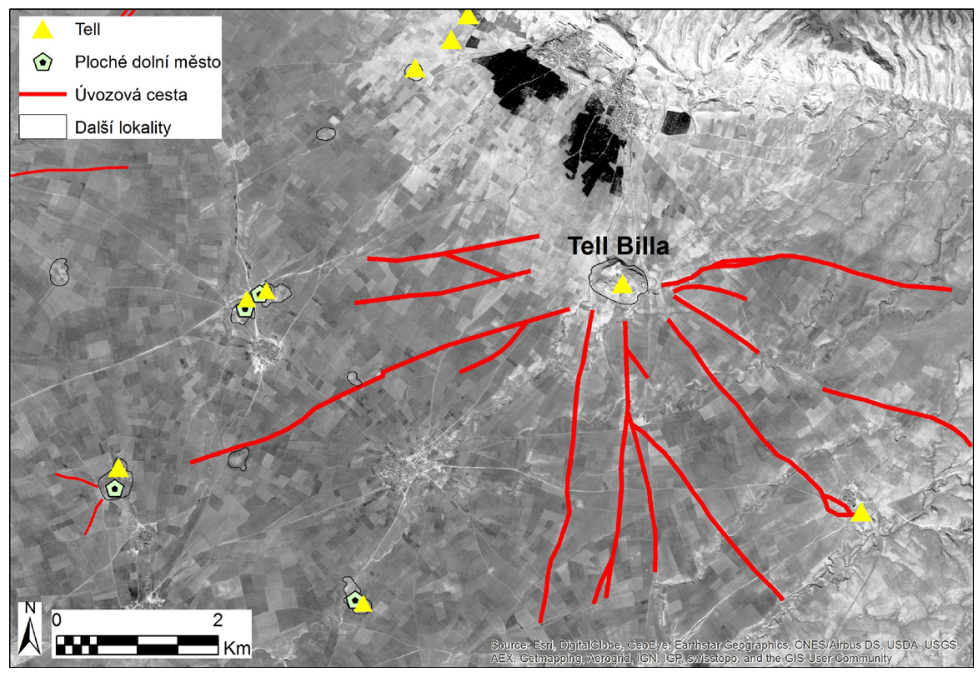

Přiloha 3. Tell Billa a okolí (CORONA DS1039-2088DA035, 28. únor 1967)

stranu nevedou žádné úvozy. ${ }^{23}$ Také se tam nachází současné osídlení, které mohlo př́padné stopy cest překrýt. Při vykopávkách na tellu byly objeveny stopy sídliště z 1. poloviny 3. tisíciletí pr. Kr. ${ }^{24}$ Vrstvy 7 a 6 jsou $z$ doby kultury ninivské 5 a sahají až do doby akkadské ${ }^{25}$ Ve středoasyrské a novoasyrské době bylo město Šibaniba významným provinčním centrem. ${ }^{26}$ Jednalo se tedy o dlouhodobě významné sídliště, které vzniklo v rané době bronzové.

\section{Další sídliště}

Asi 30 km západně od Mosulu se nachází skupina lokalit, z nichž hned 4 datujeme do rané doby bronzové (Př́loha 4). Za hlavní centrum tam můžeme považovat lokalitu Tell as-Salami, která vykazuje stopy

\footnotetext{
23 Král 2016, 133-134.

24 Finkelstein 1953, 114.

25 Roaf - Killick 1987, 202, 214.

${ }^{26}$ Finkelstein 1953, 114.
} 


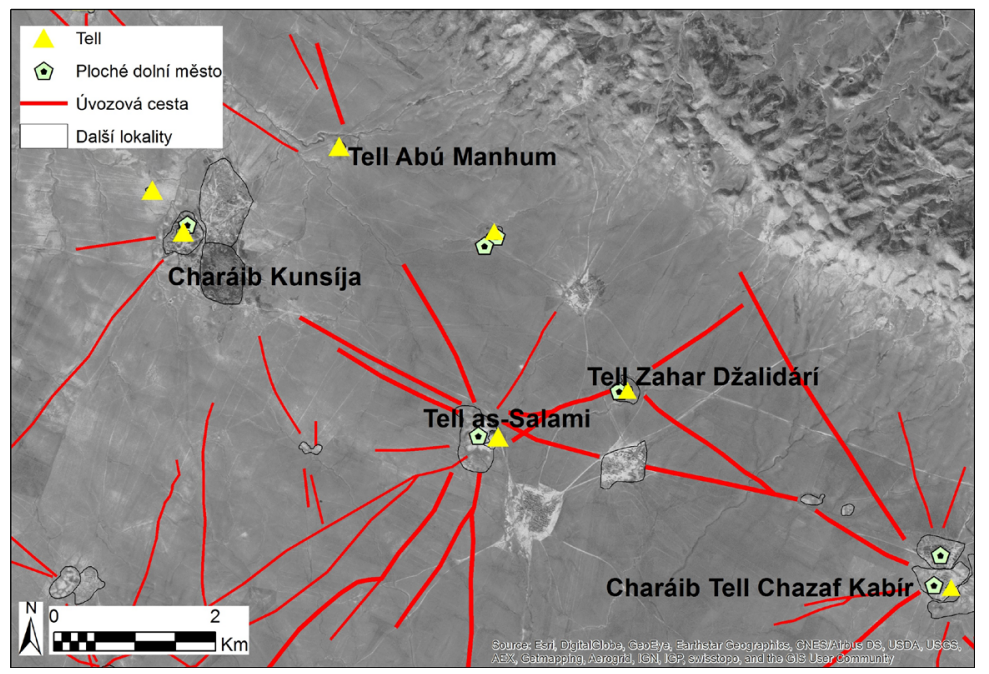

Př́loha 4. Tell as-Salami a okolí (CORONA DS1039-2088DA035, 28. únor 1967)

osídlení od hassúnské kultury až po konec 3. tisíciletí př. Kr. V době kultury ninivské 5 se v okolí nacházelo několik lokalit, které lze většinou chápat jako služebné osady či sekundární centra (Charáib Kunsíja, Tell Abú Manhum, Tell Zahar Džalidárí). Tell as-Salami je z nich největší. Skládá se z tellu (2,6 ha) a výrazného dolního města (30 ha). Okolní krajinu protíná radiální systém úvozových cest, které směrují do volného prostoru či k jiným lokalitám. ${ }^{27}$ Největší z nich je patrně Charáib Kunsíja, jež se skládá rovněž z tellu (1,8 ha) a dolního města (16,5 ha) a nachází se 4,3 km od Tell as-Salami. Osídlení je tam doloženo pro dobu ninivskou 5, novoasyrskou a islámskou. Stejně je tomu v prípadě lokality Tell Abú Manhum. Jedná se však o izolovaný tell, jehož směrem vede úvoz od Tell as-Salami. Snad by také mohlo jít o satelitní osadu. ${ }^{28}$ Nejbliže své střediskové obci byl Tell Zahar Džalidárí. Tento menší tell (1 ha) s dolním městem (7,5 ha) se nachází pouze $2 \mathrm{~km}$ západně od svého centra a datujeme ho do doby ninivské 5 .

27 Král 2016, 132.

28 Král 2016, 116. 


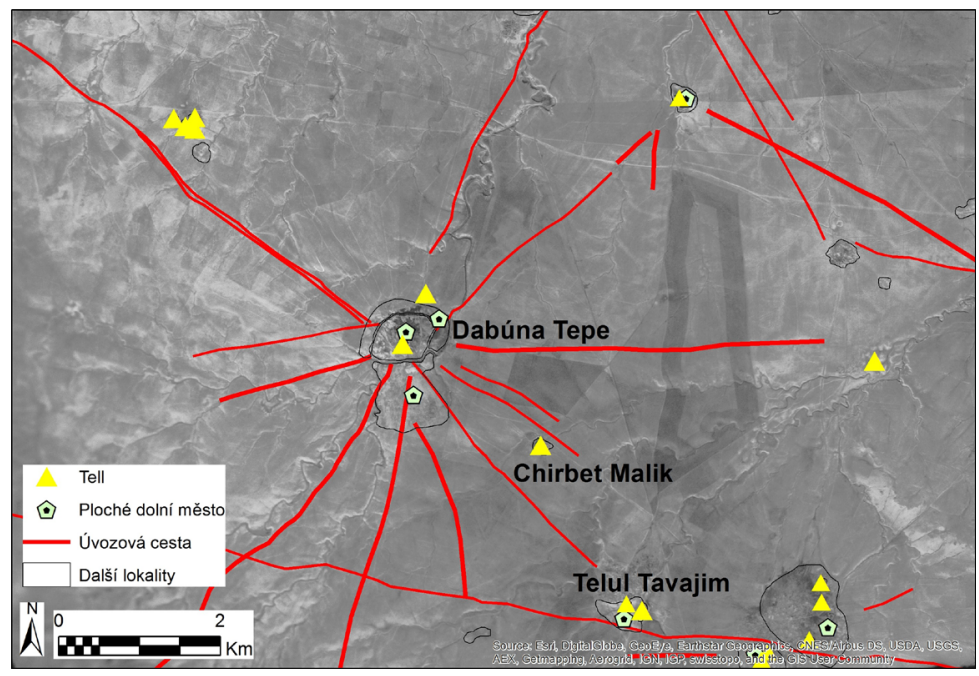

Príloha 5. Dabúna Tepe, Telul Tavajim a okolí (CORONA DS1039-2088DA034, 28. únor 1967)

Přibližně 40 km na západ od Mosulu leží Telul Tavajim (Přiloha 5). Skládá se z většího a menšího tellu, mezi nimiž se rozprostírá dolní město. Jedinou dataci, kterou Ize pro Telul Tavajim prozatím uvést, je kultura ninivská 5. Tuto lokalitu spojuje 4,3km dlouhá úvozová cesta s Dabúna Tepe. Jeho dataci bohužel neznáme, ale snad by mohlo jít o jedno ze střediskových sídlišt rané doby bronzové. Skládá se z malého tellu a dolního města, které má na severní straně relikty opevnění (Příloha 6). Celková rozloha je asi 35 ha. Stopy osídlení jsou rovněž mimo opevněný areál. Toto sídliště tedy mohlo mít až 60 ha. Poměrně výrazný radiální systém cest, jejichž šir̂́ka odkazuje na ranou dobu bronzovou, a spojení s lokalitou Telul Tavajim jsou v současnosti jedinými vodítky pro dataci tohoto výrazného sídliště. Součástí lokálního sídelního systému jsou zde i další lokality, které mohly být satelitními osadami pro Dabúna Tepe. ${ }^{29}$ Jednou z nich je např́klad Chirbet Malik, jehož dataci bohužel neznáme, ale nejspiše jde taktéž o sídliště rané doby bronzové. ${ }^{30}$

29 Král 2016, 112-113.

30 Král 2016, 123. 


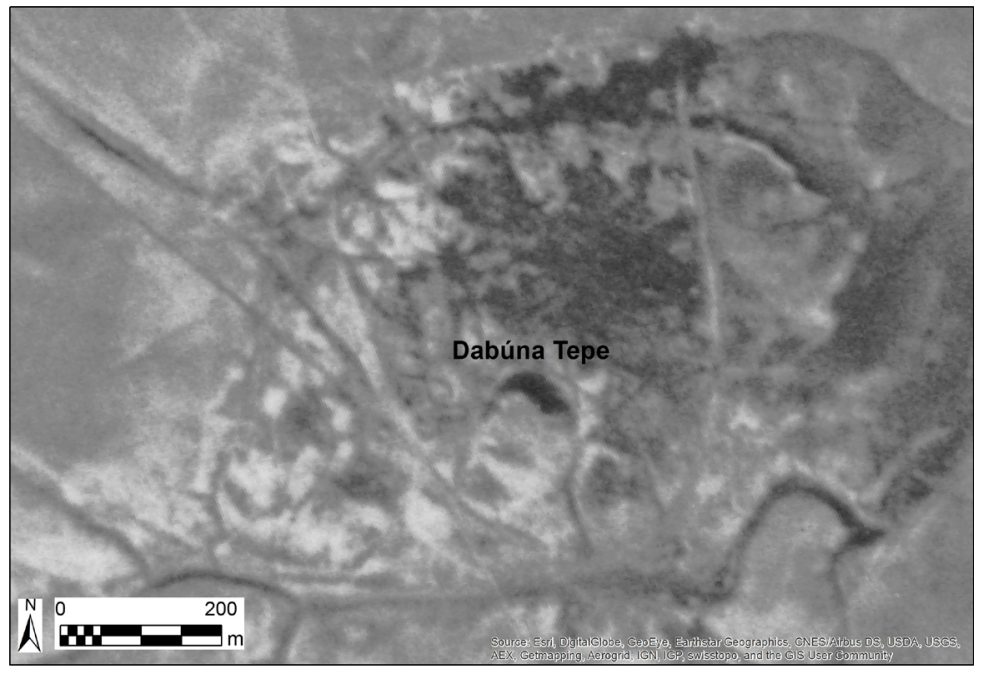

Přiloha 6. Dabúna Tepe, detail (CORONA DS1039-2088DA034, 28. únor 1967)

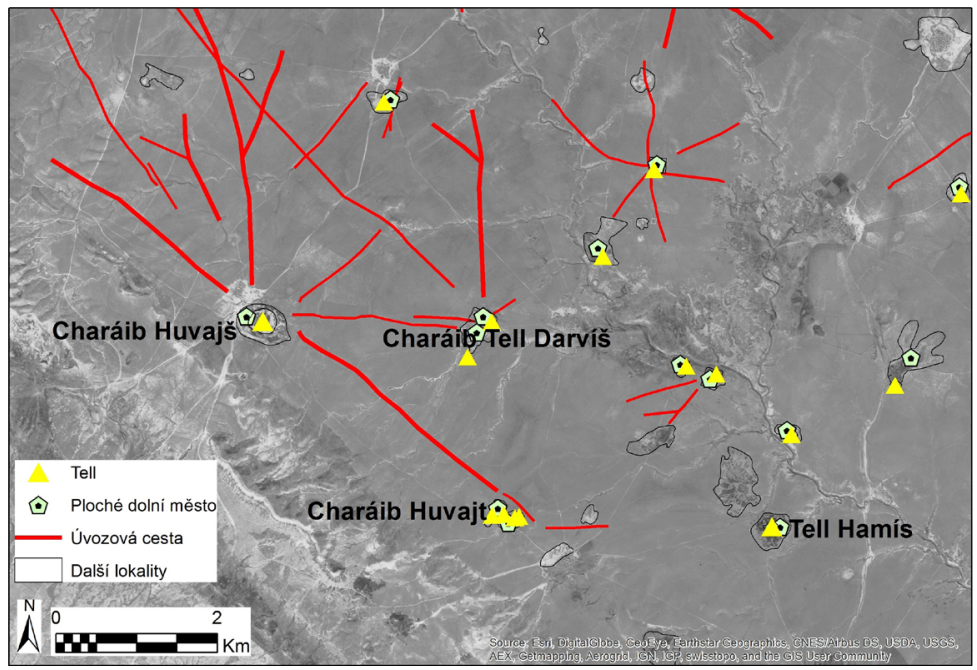

Přiloha 7. Charáib Huvajš, Charáib Huvajt, Charáib Tell Darvišs, Tell Hamís (CORONA DS1039-2088DA036, 28. únor 1967) 
Nejasnosti panují ohledně okolí lokality Charáib Huvajš (P̌̌iloha 7), která leží asi 30 km jihozápadně od Mosulu. Doložená je sice pouze datace do novoasyrského období, ale výška tellu s dolním městem (8,5 a 17 ha) oproti okolní krajině a radiální systém cest vedoucí ke starším lokalitám dává tušit možnou dataci do rané doby bronzové. Jeden z širokých úvozů vede 4,5 km jihovýchodně, kde leží Charáib Huvajt, který byl osídlen v době ninivské 5 , středoasyrské a novoasyrské. Lokalita se skládá ze čtyř malých tellů a tři dolních měst, která dohromady pokrývají plochu asi 9,5 ha. Z pozdního 3. tisíciletí př. Kr. a novoasyrské doby pochází Charáib Tell Darvišs ležící na dalším úvozu 3 km od lokality Charáib Huvajšs. ${ }^{31}$ Spiše izolovaně pưsobí Tell Hamís, který se nachází jen asi 1 km od Charáib Huvajtu. Malý tell $(1,6$ ha) obklopuje dolní město (15 ha) a jediná doložená datace pro tuto lokalitu je doba kultury ninivské $5{ }^{32}$ Vyvstává tedy otázka o pozici sídliště $\checkmark$ rámci struktury osídlení regionu.

Vedle sídelních systémů skládajících se ze střediskových a služebných sídlišt máme doklady také pro několik drobných sídlištních areálü, které mohly existovat samostatně. U mnohých z nich se ale předpokládá, že byly napojeny na sít dálkového obchodu. Z těch známějších a prozkoumaných lokalit můžeme uvést Tepe Gauru. Jde spišse o malou lokalitu, nebot má pouze 2-3 ha. ${ }^{33}$ Svũj rozkvět prožila v 5 . a 4. tisíciletí př. Kr. Po nějaký čas byla snad lokálním sekundárním centrem, které ovládalo okolní vesnice. ${ }^{34} \mathrm{Na}$ počátku 3. tisíciletí př. Kr. byla po krátké přestávce opětovně osídlena, ale už se netěšila takovému významu jako dřive. Raná fáze keramiky ninivské 5 se začala vyskytovat ve vrstvě VIII-A. Nalezena byla také ve vrstvách VII a VI, ale zde již se vyskytovala také akkadská keramika. Zdá se tedy být patrné, že v období pozdní fáze kultury ninivské 5 došlo k přerušení osídlení. ${ }^{35}$ Vrstvy V a IV datujeme do konce 3. tisíciletí př. Kr. Minimálně od vrstvy VI byla Tepe Gaura pouze jednou z obchodních stanic, přes které do akkadské

31 Král 2016, 115.

32 Král 2016, 135.

33 Král 2016, 144-145.

34 Rothman 2002, 11.

35 Roaf - Killick 1987, 202, 215. 
říše proudily cenné materiály, zvláště kovy. Tepe Gaura však ztratila svůj původní význam a zastávala spíše pozici zemědělské vesnice se sekundárním strategickým významem. Ve vrstvách V a IV byly objeveny budovy, které lze interpretovat jako opevněné domy či skladiště. Celkově byla pro tuto lokalitu raná doba bronzová velice neklidným obdobím. Svědčí o tom fakt, že vrstvy VIII, VI, V a IV byly zničeny požárem. ${ }^{36}$

Jen asi 3 km jihozápadně od Tepe Gaury se nachází Tepe Čenči. Vykopávky tam probíhaly pouze několik týdnů ve 30 . letech 20. století, přesto výzkum této lokality obohatil naše poznání o struktuře osídlení této části severní Mezopotámie. Tepe Čenči bylo osídleno již v době haláfské a obejdské kultury. Tehdy však rozhodně nedosahovalo významu, kterému se těšila Tepe Gaura. Podobně tomu bylo také v období ninivském 5. Změna však nastala v pozdním 3. tisíciletí př Kr. Díky výzkumu byla na lokalitě rozpoznána jakási terasa z akkadského období. Šlo nejspíše o stavbu veřejného charakteru a zdá se, že lokalita, ačkoli měla jen 2 ha, byla něčím významná. Patrně tou dobou nebyla pouhou zemědělskou vesnicí a z neznámého důvodu zastínila Tepe Gauru, která tehdy měla už jen asi 0,5 ha a tamní domy připomínaly prosté zemědělské usedlosti. Tepe Čenči mohlo získat na významu díky spojení s nějakým významným městským centrem, jakým bylo třeba Ninive. Mohlo jít o jakousi jeho předsunutou pevnost. Vznik státního útvaru s centrem v Ninive, které ovládalo okolní pláně, by mohlo vysvětlovat také úpadek Tepe Gaury, která by politickým sjednocením regionu ztratila své jedinečné postavení ${ }^{37}$

Sídlištěm spíše izolovaným a vázaným na dálkový obchod mohl být také Nimrúd, starověký Kalach, který byl v pozdním 3. tisíciletí př. Kr. pouhou vesnicí. ${ }^{38}$ Ve staroasyrském období se toto místo nazývalo Kamilchu či Kavalchu a bylo jednou ze stanic dálkového obchodu. ${ }^{39}$ Je možné, že tento svưj charakter sídliště získalo už v počátcích své existence.

\footnotetext{
36 Rothmann 1997, 180.

37 Algaze 1989, 14-16.

38 Oguchi 1997, 206.

39 Ziegler 2002, 270.
} 
Mezi lokality ležící na dálkových obchodních trasách patří také dlouhodobě osídlená Abú Maria. Obydlená byla v první fázi rané doby bronzové, tedy v době ninivské 5 . Procházela přes ni cesta z východu na západ. Po celá staletí se jednalo o důležité sídliště, které lidé dodnes obývají. Určitou protiváhou mu však byl nedaleký Tell 'Afar. ${ }^{40}$

Al-DŽirn představuje nejspiše kombinaci střediskových sídlišt a obchodních stanic. Okolní krajina je protnuta několika radiálními cestami různých širrek. Některé $z$ nich vedou $\mathrm{k}$ menším lokalitám v okruhu 1,5-5,5 km. Jelikož Al-Džirn vykazuje stopy osídlení z pravěkých období, kultury ninivské 5, staroasyrského a islámského období, i okolní sídla mohou mít různou dataci. Některá bychom patrně mohli považovat za satelitní sídlištní areály. Al-Džirn ležel na dálkové cestě, která vedla od jihu podél Tigridu a u soutoku s Velkým Zábem se stáčela na severozápad. Snad jde o cestu popisovanou ve starobabylónských itineráŕích cest. V takovém prípadě by lokalita plnila funkci stanice obchodníků. ${ }^{41}$

Z dálkového obchodu mohla tě̌̌it také lokalita Chirbet Abú Šeka, která leží 35 km západně od Mosulu. Osídlení je tam doloženo pro dobu obejdskou, ninivskou 5 a novoasyrskou. Možná šlo o satelitní osadu Tell Herady, od níz vede k sídlišti 2,5km dlouhá široká úvozová cesta. Přestože Tell Herada je datovaná pouze do novoasyrského období, velikost tellu naznačuje, že by tamní osídlení mohlo mít mnohem delší historii. ${ }^{42}$ Kolem obou lokalit prochází dálková cesta od jihozápadu směrem k Mosulu. Přímo na ní však leží jiná sídliště, která Ize interpretovat jako obchodní stanice s větší jistotou.

Ne všechny izolované lokality musely být vázány na dálkový obchod. Dokladem je napríklad Chirbet az-Zaftija, jež byla patrně prostou vesnicí doby sámarrské, haláfské a později také ninivské $5 .{ }^{43}$

\footnotetext{
40 Král 2016, 110-111.

41 Král 2016, 111-112.

42 Král 2016, 136.

43 Král 2016, 121.
} 


\section{Závěr}

V krajině okolo Mosulu se v rané době bronzové nacházelo několik regionálních center, která kolem sebe soustředila menší sídliště. Ta často ležela na úvozových cestách svých střediskových obcí a Ize je chápat jako satelitní osady s nižším postavením v rámci lokální hierarchie sídlišt'. Tuto situaci známe také z jiných oblastí severní Mezopotámie, napríklad ze severní Džazíry. Z písemných pramenů známe Ninive, které bylo centrem nadregionálního víznamu. Sehrálo tak významnou úlohu při formování prvních státních útvarů v severní Mezopotámii. Za pozůstatky regionálních center oblastního charakteru lze poté chápat lokality Tell Billa, Tell as-Salami a patrně Dabúna Tepe a Charáib Huvajš. Nejspiše právě zde došlo formování společenských a ekonomických struktur potřebných pro vznik raných států. V okolí těchto center nacházíme lokality, které považujeme za služebné osady - satelity (Charáib Huvajt, Charáib Kunsíja, Charáib Tell Darvišs, Chirbet Abú Šeka, Tell Abú Manhum, Tell Zahar Džalidárí, Telul Tavajim).

V krajině se nacházelo také několik sídlišt', která byla více či méně izolovaná a mnohdy tušíme jejich napojení na sít dálkových cest. Některá z těchto sídlišt mají vlastní radiální systém úvozů a patrně mohla ovládat okolní vesnice. Jedná se zvláště o lokality Abú Maria a Al-Džirn. Určitý strategický význam měla patrně také drobná sídliště Tepe Gaura a Tepe Čenči. Dnešní Nimrúd mohl být prostou vesnicí, která sloužila obchodníkům jako zastávka na jejich trase z jižní Mezopotámie do Sýrie a Anatólie. V krajině bychom nalezli rovněž sídliště, která nejspišs nebyla vázána na ostatní. Jmenovat můžeme lokality Chirbet az-Zaftíja a Tell Hamís.

Je velice pravděpodobné, že v okolí Mosulu bylo více sídlišt, než kolik jich máme doložených. Na snímcích CORONA pro tuto část severní Mezopotámie je možné nalézt asi 800 potenciálních archeologických lokalit, ale jen zhruba 10 \% z nich můžeme datovat. ${ }^{44}$ Současná politická a bezpečnostní situace bohužel znemožňuje jakýkoli terénní průzkum, který by nám pomohl určit datace více lokalit.

44 Král 2016, 190. 


\section{Summary}

During the Early Bronze Age, there were some regional centers surrounded by smaller settlements in the landscape around Mosul. They were often located on hollow ways of the centers, and we can see them as satellite settlements of lower status in the local settlement hierarchy. We know this situation from other regions of the northern Mesopotamia, for example from North Jazira. Based on the written sources we know only Nineveh which was a centre of supraregional importance. Nineveh played a part in the formation of the first states in northern Mesopotamia. As the relicts of regional centers with distinctive radial system of hollow ways we can regard sites Tell Billa, Tell as-Salami, and maybe also Dabuna Tepe and Kharaib Huwaish. These centers were the focuses of formation of economic, and social structures which are necessary for the origin of early states. In the hinterland of those centers, we see some sites which we can interpret as ancillary settlements - satellites (Kharaib Huwait, Kharaib Kunsiya, Kharaib Tell Darvish, Khirbet Abu Sheka, Tell Abu Manhum, Tell Zahar Jalidari, Telul Tawayim).

In the landscape, there were also several settlements which were more or less isolated. Sometimes we surmise a link-up to the network of long trade routes. Some of these settlements have radial system of hollow ways around themselves and they could probably control the surrounding villages. Abu Maria and al-Jirn belong to this group. We can assume a local strategic importance in case of smaller sites - Tepe Gawra, and Tepe Chenchi. During the Early Bronze Age, Nimrud could be an ordinary village used as a station for merchants travelling from southern Mesopotamia into Syria and Anatolia. Small isolated sites without connection to others settlements occurred in the landscape around Mosul, as well (for example Khirbet az-Zaftiya and Tell Hamis).

It is very probable that there were much more settlements in the landscape around Mosul than proved now. On CORONA images, we can find ca 800 potential archaeological sites in this part of northern Mesopotamia. Nevertheless, we know the dating only for $10 \%$ of the 
total amount of sites. ${ }^{45}$ Unfortunately, the current political and security situation of the Mosul area in northern Iraq limits the possibility of any field works which would by very useful for the determination of dating of the rest of sites.

${ }^{45}$ Král 2016, 190. 


\section{Bibliografie}

Algaze, Gulliermo. 1989. „Tepe Chenchi: An Important Settlement Near Khorsabad." In Essays in Ancient Civilization presented to Helene J. Kantor, vyd. Albert Leonard a Bruce Williams, 1-31. Chicago: Oriental Institute of the University of Chicago.

Altaweel, Mark. 2003. „The Roads of Ashur and Nineveh.” Akkadica 124: 221-228.

Ball, Warwick a Tony Wilkinson. 1989-90. „British Work in the North Jazira Project 1986-87: Preliminary Report." Sumer 46: 7-12.

Directorate General of Antiquities. 1970. Archaelogical Sites In Iraq. Baghdad.

Directorate General of Antiquities. 1976. Atlas of Archaeological Sites In Iraq. Baghdad.

Finkelstein, Jacob. 1953. „Cuneiform Texts from Tell Billa.” Journal of Cuneiform Studies 7: 111-176.

Král, Pavel. 2012. Počátky asyrské kultury. Nepublikovaná diplomová práce. Plzeň: Západočeská univerzita v Plzni, Fakulta filosofická.

Král, Pavel. 2016. Krajina v zázemí asyrských metropolí. Nepublikovaná disertační práce. Plzeň: Západočeská univerzita v Plzni, Fakulta filosofická.

Matthews, Donald. 1997. The Early Glyptic of Tell Brak: Cylinder Seals of the Third Millennium Syria(Orbis Biblicus et Orientalis, Series Archaeologica 15). Freiburg - Göttingen: Universitätsverlag - Vandenhoeck \& Ruprecht. Oguchi, Hiromichi. 1997. „A Reassessment of the Distribution of Khabur Ware: An Approach from an Aspect of Its Main Phase." Al-Rafidan 18: 195-224.

Reade, Julian. 2000. "Ninive (Nineveh).“ In Reallexikon der Assyriologie und vorderasiatische Archäologie, Band 9, Nimrūd - Ninlil, vyd. Dietz Otto Edzard, 388-433. Berlin - New York: Walter de Gruyter.

Ristvet, Lauren a Harvey Weiss. 2000. "Imperial Responses to Environmental Dynamics at Late Third Millennium Tell Leilan." Orient-Express 4: 94-99. 
Roaf, Michael a Robert Killick. 1987. „A Mysterious Affair of Styles: The Ninevite 5 Pottery of Northern Mesopotamia." Iraq 49: 199-230. Rothman, Mitchell. 1997. „Tepe Gawra.” In The Oxford Encyclopedia of Archaeology in the Near East, Vol. 5, vyd. Eric Meyers, 183-186. New York - Oxford: Oxford University Press.

Rothman, Mitchell. 2002. Tepe Gawra: The Evolution of a Small, Prehistoric Center in Northern Iraq. Philadelphia: University of Pennsylvania.

Sallaberger, Walther a Aage Westenholz. 1999. Mesopotamien - Akkade-Zeit und Ur III-Zeit (Orbis Biblicus et Orientalis 160/3). Freiburg - Göttingen: Universitätsverlag - Vandenhoeck \& Ruprecht.

Steinkeller, Piotr. 1991. „The Administrative and Economic Organization of the Ur III State: The Core and the Periphery." In The Organization of Power - Aspects of Bureaucracy in the Ancient Near East, vyd. McGuire Gibson a Robert Biggs, 15-33. Chicago: Oriental Institute of the University of Chicago.

Stronach, David. 1994. „Village to Metropolis: Nineveh and the Beginnings of Urbanism in Northern Mesopotamia." In Nuove Fondazioni nel Vicino Oriente Antico: Realta e ideologia, vyd. Stephanie Mazzoni, 85-114. Pisa: Giardini.

Ur, Jason. 2003. „CORONA Satellite Photography and Ancient Road Networks: A Northern Mesopotamian Case Study." Antiquity 77: 102-115.

Ur, Jason. 2012. „Spatial Scale and Urban Evolution at Tell Brak and Hamoukar at the End of the 3rd Millennium BC." In Looking North: The Socio-Economic Dynamics of the Northern Mesopotamian and Anatolian Regions during the Late Third and Early Second Millennium $B C$, vyd. Nicola Laneri, Peter Pfälzner a Stefano Valentini, 25-35. Tübingen: Harrassowitz.

Ur, Jason. 2013. „Spying on the Past: Declassified Intelligence SateIlite Photographs and Near Eastern Landscapes." Near Eastern Archaeology 76: 28-36. 
Ur, Jason, Lidewyjde De Jong, Jessica Giraud, James Osborne a John MacGinnis. 2013. „Ancient Cities and Landscapes in the Kurdistan Region of Iraq: The Erbil Plain Archaeological Survey 2012 Season." Iraq 75: 89-117.

Weiss, Harvey a kol. 1993. „The Genesis and Collapse of Third Millennium North Mesopotamian Civilization." Science 261: 995-1004.

Westenholz, Joan Goodnick. 2004. „The Old Akkadian Presence in Nineveh: Fact or Fiction." Iraq 66: 7-18.

Whiting, Robert. 1976. "Tiš-Atal of Nineveh and Babati, Uncle of Šu-Sin." Journal of Cuneiform Studies 28: 173-182.

Wilkinson, Tony. 1990. „Development of Settlement in the North Jazira between the 7th and 1st Millennia BC." Iraq 52: 49-62.

Wilkinson, Tony a David Tucker. 1995. Settlement Development in the North Jazira, Iraq: A Study of the Archaeological Landscape. Warminster: Aris \& Philips.

Ziegler, Nele. 2002. „Le royaume d'Ekallâtum et son horizon géopolitique." Florilegium Marianum 6: 211-274.

\section{Snímky CORONA:}

CORONA DS1039-2088DA034, 28. únor 1967

CORONA DS1039-2088DA035, 28. únor 1967

CORONA DS1039-2088DA036, 28. únor 1967

CORONA DS1039-2088DA037, 28. únor 1967 


\section{Kateřina Šašková}

\section{Asyrský král Asarhaddon v péči dvorních lékařù}

\section{„Proč nezjistíš povahu této mé choroby, nenajdeš na ni lék?" 46}

Otázku použitou v titulu klade král Asarhaddon svému dvornímu lékaři, Urad-Nanāiovi, a svým způsobem je pro tohoto panovníka př́iznačná. Když zazní Asarhaddonovo jméno, jen zřídka spolu s ním není zmíněno královo chatrné tělesné zdraví. Asarhaddon je často představován jako král až přehnaně úzkostlivý, i ve své době abnormálně zbožný a jeho špatné zdraví je mnohdy považováno za nejcharakterističtější rys jeho vlády.

\section{Prameny}

Z hlediska různorodosti i množství pramenů je druhá půle novoasyrského období dobou relativní hojnosti. V souvislosti s medicínou jsou zvláště důležité texty, jejichž autory jsou odborníci v různých odvětvích mezopotamské vědy, kteří byli zaměstnáni u královského dvora a jejichž hlavním úkolem byla péče o zdraví panovníka i celé královské rodiny. Tyto texty, zejména korespondence a v menší mîre také věštebné dotazy, alespoň částečně odhalují, jak byla konkrétní nemocná osoba léčena a kdo byl tím, jenž průběh nemoci sledoval a určoval př́islušné procedury a medikaci. ${ }^{47}$

46 SAA X 315, 8-10.

47 Přesto však nelze tyto texty chápat jako zdroj informací k medicínské praxi 
Většinu těchto textů Ize více či méně přesně datovat a je zjevné, že prakticky všechny texty týkající se medicínských (a také rituálních) záležitostí pocházejí právě z Asarhaddonovy doby. ${ }^{48}$ Téměř výlučná koncentrace do období vlády jednoho panovníka je zvláštní, protože z jiných zdrojů víme, že učenci zabývající se léčbou působili rovněž na dvorech předchozích asyrských vladařủ a v Asarhaddonově době již byla jejich pozice u dvora pevně ukotvena. Lze tedy předpokládat, že podobné dopisy vznikaly i za vlády jiných novoasyrských králü. ${ }^{49}$ Častým (a větší měrou zřejmě pravdivým) vysvětlením velkého podílu dopisů s touto tematikou z Asarhaddonovy doby je právě králův špatný zdravotní stav. Ani tento fakt ale dostatečně nevysvětluje absenci podobných textů přinejmenším z období vlády jeho bezprostředních předchůdců, jejichž politická korespondence se alespoň částečně dochovala.

\section{Lékaři}

Panovníkovo zdraví či nepohoda, v tělesné i rituální rovině, měly v asyrském chápání královského úřadu celospolečenský dosah, není tedy divu, že o Asarhaddona pečovalo velké množství osob. Pokud panovník onemocněl, bylo jejich úkolem dopátrat se př́činy a všemi možnými prostředky zajistit nápravu. Pro panovníka pracovali četní učenci (ummânū), z nichž se pak vyčlenila skupina 15 či 16 nejváženějších mužůu, ${ }^{50}$ kteří stáli králi nejblíže a zároveň jsou autory většiny dochovaných dopisů. ${ }^{51}$ Nejvýše postavení královští učenci vykonávali profesi astrologa/písaře (țupšarru), naříkače (kalû), zaříkávače (āšipu), haruspika (bārû) či lékaře (asû), ${ }^{52}$ ale někteří z nich se orientovali ve více oborech zároveň.

ve starověké Mezopotámii obecně, nebot' se vztahují výlučně k vysoce postaveným osobám, v naprosté většině k panovníkovi a členům jeho rodiny.

${ }^{48}$ SAA X, XXIX-XXX. Dopisy pokrývají poměrně krátké období 35 let, nejvíce jich pochází z doby mezi lety 672-669 (Parpola 1983, XIII).

${ }^{49}$ Parpola 1983, XII, SAA IV, XXI, SAA X, XXIX-XXX.

50 Parpola 1983, XV-XVI, srov. SAA X, XXVI.

51 Parpola 1983, XIV. Viz též autory dopisů v Parpola 1970, SAA VIII a SAA X.

52 Např. SAA X, XIII a XXXIV pozn. 1. Viz též Geller 2010, 75. 
V záležitostech souvisejících se zdravím krále Asarhaddona se pochopitelně angažovali muži s tituly asû. Ti ale nejsou jediní a v textech souvisejících s medicínou figurují často také osoby titulované jako āšipu. ${ }^{53}$ Termín asû je tradičně překládán jako lékař jako takovy, ${ }^{54}$ tedy odborník $\checkmark$ lečení chorob pomocí medikamentů. ${ }^{55}$ Profese āšipu je na druhé straně překládána jako zařikávač ${ }^{56}$ a jeho hlavní doménou bylo „ovlivňovánínadpřirozených sil pomocí magie" ${ }^{57}$ Asû by tedy měl být podle této definice spíše praktikem zabývajícím se tělesnem, zatímco āšipu měl provádět podpưrné rituály a za pomoci magie ovlivňovat nadpřirozené síly.

Asarhaddonova korespondence však ukazuje, že toto rozdělení je př́liš zjednodušené a hranice oddělující obě profese nebyla zdaleka tak ostrá. Ač by se mohlo zdát, že taková procedura, jakou je vyšetření pacienta, spadá do pravomoci asû, pacienta často vyšetřoval āšipu, ${ }^{58}$ který také mohl naordinovat užití určitých léčiv. ${ }^{59} \mathrm{~A}$ naopak i asû mohl pacientovi doporučit vykonání nějakého rituálu ${ }^{60}$ nebo použití amuletů, které mohl dokonce sám nemocnému poslat. ${ }^{61}$ Sám Asarhaddon se na své zdraví a řešení různých tělesných obtǐź dotazoval mužů obou profesí a stejně tak jej o zdraví jeho i ostatních členů královské rodiny informovali asû i āšipu. Okrajově je královo zdraví rovněž tématem dopisů králových astrologů.

53 Zprávy āšipu dokonce převažují, ale právě v případě královy osoby jsou v menšině.

54 CAD A ${ }_{2}$, 344. V sumerštině A.ZU znamená doslova „znalec vody“ (AHw, 76).

55 Např. Parpola 1983, XIV.

${ }^{56}$ CAD A 431.

57 Parpola 1983, XIV.

58 Douek 2007, 216-217. V dopisech, v nichž je zmíněno vyšetření pacienta, tuto činnost skutečně prováděl āšipu (SAA X 202, rev. 8'-9'; SAA X 230, 3’), nicméně vyšetření a diagnostika zjevně nebyly v rukou āšipu výhradně a například větou užitou v názvu tohoto textu se Asarhaddon obrací na asû Urad-Nanāiu.

59 Adad-šumu-ușur v textu SAA X 191 (5-10) radí ohledně požití léku. Marduk-šākinšumi králi doporučuje léčivý obklad (SAA X 241, 5-6) a jinde zase řeší užití masti a vykuřovacích prostředků (SAA X 250, 8'-9').

${ }^{60}$ Urad-Nanāia poslal králi byliny vhodné k rituálu ušburrudû (SAA X 316, rev. 15-21) a v textu SAA X 321 doporučuje zaklínání. K ušburrudû a jejich příslušnosti k asûtu či āšipūtu viz Parpola 1983, 147.

${ }^{61}$ Podle dopisu SAA X 315 (rev. 15 -r.e. 18) poslal Urad-Nanāia králi amulety a stejně tak i lkkāru (SAA X 328, 8-10). 
Z asû se ve zprávách týkajících se králova zdraví nejčastěji objevuje Urad-Nanāia, Asarhaddonův nejvyšší lékař. ${ }^{22}$ Vedle něho byl dalším autorem dopisů s titulem asû lkkāru, ${ }^{63}$ jenž snad mohl být Urad-Nanāiovým předchůdcem ve funkci vrchního lékaře. ${ }^{64}$ Zprávy āšipu jsou zastoupeny dopisy Marduk-šākin-šumiho, ${ }^{65}$ vrchního āšipu, a texty hlavního králova osobního āšipu Adad-šumu-ușura. ${ }^{66}$ S královým zdravím souvisí rovněž dopis SAA X 43, jehož autory jsou astrologové Balasî a Nabû-ahb̧ēe-erība, a dva texty Issār-šumu-ēreše, ${ }^{67}$ Asarhaddonova vrchního písaře a astrologa.

\section{Zprávy o králově zdraví}

\section{Sezónní a běžná onemocnění}

Ani panovníkovi se nevyhýbala běžná onemocnění, a tak u něho máme v srpnu roku 672 či 671 př. n. I. ${ }^{68}$ doloženu zimnici či nachlazení. ${ }^{69}$ Tyto obtǐze byly považovány za sezónní chorobu, u které bylo předpokládáno rychlé vyléčení, a nejvyšší āšipu, Marduk-šākin-šumi, králi pišs: „Pokud jde o nachlazení, o němž mi král, můj pán, psal, není důvod se tím znepokojovat. Bohové k[rále] je rychle vyléči a my budeme dělat vše, co je pro tuto záležitost důležité. [Je to] sezónní onemocnění; král, můj pán, by se neměl [obálvat." ${ }^{\text {"70 }}$ Pravděpodobně k téže události se vztahuje zpráva, v níž astrolog Issār-šumu-ēreš Asarhaddonovi napsal: "Král se tímto onemocněním nemusí znepokojovat. Je to sezónní choroba; všichni lidé, kteři byli nemocní, jsou (nyní) v pořádku. (...)

62 SAA X 315, SAA X 316, SAA X 318, SAA X 323, SAA X 324 a SAA X 325 a snad SAAX 327.

${ }^{63}$ Krále se prokazatelně týká pouze text SAA X 328.

${ }^{64}$ SAA X, XXVI.

65 SAA X 241, SAA X 242, SAA X 243 a snad SAA X 250.

${ }_{66}^{6}$ SAA X 196.

67 Texty SAA X 37 a SAA VIII 1.

${ }^{68}$ Dopis SAA X 236 je považován za soudobý s následující zprávou Issār-šumu-ēreše SAA VIII 1, kterou Parpola datuje do srpna roku 672 př. n. I. (Parpola 1983, 173-174 a 422; SAA X, 188), kdežto H. Hunger do roku 671 př. n. I. (SAA VIII, 4).

${ }^{69}$ Kūṣu, nachlazení, zimnice (CAD K, 594). S kūṣu se panovník potýkal i roku 670 př. n. I., kdy se však žrejmě jednalo o vážněǰši prípad. Viz níže.

70 SAA X 236, 5-13. 
Kdesi se praví toto: „Daři se mu velmi dobře - jeho dny budou krátké; je neustále nemocen - jeho dny budou dlouhé." "'71

\section{Vážné zdravotní potíže}

Vedle běžných nemocí však Asarhaddon trpěl v posledních letech života také celou řadou vážných potǐž, které byly fyzického i psychického rázu.

\section{Doklady do roku 671 pr. n. I.}

0 Asarhaddonově zdraví máme naprostou většinu zpráv až ze závěrečných tř̌ let jeho vlády, ovšem na základě některých indicií je možné se domnívat, že zřejmě nebyl zcela zdráv ani před svým nástupem na trůn a zpočátku své vlády. ${ }^{72}$ Například lékař Ikkāru zmiňuje období, kdy byl král ještě korunním princem, v souvislosti se zánětem očí. ${ }^{73}$ Také ve smlouvě z roku 697 př. n. I. je kupujícím jistý Šemabu, který je titulován jako Asarhaddonův asû. ${ }^{74}$ Zvláštní na tomto titulu je, že je jeho součástí jméno pacienta, nebot jak vyplývá z královské korespondence, lékaři královské rodiny se starali o více pacientů najednou, a jejich tituly ve smlouvách zní jednoduše „lékař”, „hlavní lékař” apod.75 Předchozí potiže naznačují rovněž sami lékaři v dopisech z konce Asarhaddonovy vlády, kteři králi prípomínají, že podobná léčiva mu již připravovali dřive a že zmiňované procedury již byly prováděny. Je však otázkou, jak dlouhý časový úsek v těchto prípadech připadá v úvahu, mohlo se také jednat o rozmezí pouhých několika týdnů či měsíců.

Asarhaddonovi současníci si s královými potižemi nevěděli př́liš rady, což potvrzuje několik dochovaných věštebných dotazů k bohu Šamašovi. Z roku 672 př. n. I.76 pochází dotaz na druh Asarhaddonovy nemoci. ${ }^{77}$ Další z dotazů se pak týká toho, zda má král vypít určitý lék:

\footnotetext{
71 SAA VIII 1,6 - rev. 7.

72 Melville 1999, 35. Viz též Parpola 1980, 178 pozn. 37, a Parpola 1983, 255.

73 SAA X 328, 15-18.

74 SAA VI 126, 8-9.

75 Viz např. tituly v SAA VI.

76 Text je datován jménem Nabû-bēlu-ușura (SAA IV 183, rev. 7’), který úřad līmu zastával v roce 672 př. n. I. (Millard 1994, 103-104).

77 SAA IV 183, 1-4. V podobném duchu byl snad sepsán také velmi poškozený text SAA IV 184.
} 
„[Má Asarhaddon, král Asýrie, jak] si přeje, [vypít tento lék, (...) bude Asarhaddon], král Asýrie, vypitím tohoto lé[ku zachráněn a ušetřen? Bude žít a uzdraví se]?".78 Tento text potvrzuje, že Asarhaddonův stav byl skutečně vážný a snad byl ohrožen dokonce i jeho život. Dotaz bohužel nelze ani príbližně datovat, je tedy možné, že se vztahuje k onemocnění, které panovníka postihlo o dva roky později.

\section{Zprávy z posledních dvou let vlády}

Právě z této doby, kdy král opět vážně onemocněl, zvláště z dubna či května roku 670 př. n. I., ${ }^{79}$ pochází většina zpráv. Podle záznamů se tehdy Asarhaddonova choroba projevovala různorodými - fyzickými i psychickými - obtižemi, které byly léčeny pomocí medikamentů i magických praktik.

Krále soužila zejména horečka která vyvolávala zimnici a způsobovala celkovou slabost. Urad-Nanāia napríklad v odpovědi na Asarhaddonovu otázku po povaze a léčbě jeho onemocnění píše: „Dř́ve jsem během audience ke králi hovořil a nebyl jsem schopen objasnit jeho symptomy. (...) Pokud to králi, mému pánu, vyhovuje, at' ohledně toho nechá provést věštce bārû věštbu. Necht' král použije tento roztok ${ }^{80}$ (zaslaný spolu s dopisem) a horečka $a^{81}$ krále, mého pána, pravděpodobně pomine. Tento olejový roztok jsem pro krále, mého pána, pripravoval (již) dvakrát či třikrát - král to ví. Pokud král souhlasí, müže jej použít zitt[ra]. Odstraní to chorobu. Až králi přinesou șilbānu, at' zatáhnou závěs, jak učinili jednou či dvakrát (předtím); já vstoupím a vydám pokyny. Král se pravděpodobně bude potit. V brašně králi, mému pánu, posílám jisté amulety. Král by si je měl dát kolem krku. Posilám také mast. ${ }^{82}$ Král by se měl pomazat v den (akutní) fáze (choroby). " 83

Vedle léčiv se vcelku jasným použitím (léciivý roztok či mast) je hlavní léčebnou metodou použití jakéhosi șilbānu, povaha této kúry je však

78 SAA IV 185, 1'-3'.

79 Parpola 1983, 138.

${ }^{80}$ Marhușu, roztok, výplach (Parpola et al. 2007, 61).

81 Hunțu, horečka, horkost (CAD H, 236).

82 Napšaltu, mazání, mast (CAD N, 317$)$.

${ }^{83}$ SAAX 315 , b.e. 20 -rev. 8. 
nejistá. Geller uvádí, že se jedná o křǐzem vázaný obvaz, ${ }^{84}$ Parpola naproti tomu překládá șilbānu jako léčivý obklad. ${ }^{85}$ Ve slovnících figurují oba tyto překlady. ${ }^{86}$ Zcela jednoznačný není ani význam termínu $m \bar{e}^{\prime} e l u$, který je sice v této souvislosti přeložen jako amulet, jinde se však objevuje ve významu obkladu přikládaného kolem krku. ${ }^{87}$

Șilbānu doporučuje rovněž Marduk-šākin-šumi, který zároveň upřesňuje jeho použití: „Pokud jde o použití șillibānu, o nichž král, můj pán, rekl: "„Je to velmi horké!" Musí být horké, proč bychom to (jinak) dělali? Ne(myslel na) horko, (když) řekl: "Má to způsobit, abych se potil?" Ale proč je postižen zimnicí, přestože je počátek léta? To nedává smysl. Je to dílo bohů. " ${ }^{88}$ Také on zmiňuje amulety, ${ }^{89}$ získané snad z Egypta, ${ }^{90}$ píše však o nich, že nejsou vhodné. ${ }^{91} V$ jiném dopise Marduk-šākin-šumi cituje královy obtižze způsobené horečkou: „„,Mé ruce a nohy jsou bez síly!" a "Nemohu otevř́t své oči, škrábu se a jen ležím"“.92 Vysvětluje mu, že to je „proto, že horečka se usadila v samotných kostech", ${ }^{3}$ a zároveň jej uklidňuje: „Není to vážné - Aššur, Šamaš, Bēl a Nabû zajistí zdraví. Jeho nemoc odezní - bude opět v pořádku. Věru, měli by počkat a jist (pouze) to, co je vhodné. "94 Přes toto ujištění byl však král natolik slabý,

\footnotetext{
84 Termín dává do souvislosti se západosemitským kořenem șlb, který překládá jako „kříž", a spojení pariktu lipriku (rev. 12) pak překládá ve smyslu kladení obvazu křŕžem (Geller 2010, 83 a 188 pozn. 117; srov. CAD P, 185).

${ }^{85}$ Kořen slova je podle něho spojen se syrským șulbānā, o němž píše, že jde o „suchý kořen lékořice" použitý jako obklad (Parpola 1983, 173). Spojení pariktu liprikū překládá: „at' zatáhnou závěs” (Parpola 1983, 237-238).

${ }^{86}$ Șilbānu, obklad (SAA X, 357; Parpola et al. 2007, 104), șilbu, křǐzové uspořádání obvazů či dřeva (CAD ș, 187).

87 Mēelu, obvaz, obklad kolem krku (CAD $\mathrm{M}_{2}$, 14), amulet (SAA X, 345), amulet, obklad (Parpola et al. 2007, 63).

88 SAA X 241, 5 - rev. 2.

89 Turru, struna, šňůra (CAD T, 164), „šňưra (provrtaných kamenných amuletů pověšená na krku)" (Parpola 1983, 173). SAA X 241, rev. 3.

90 Parpola 1983, 173.

91 SAA X 241, rev. 10-12.

92 SAA X 242, 6-9.

93 SAA X 242, 10-12. Doslova "huntu šū ina ŠA eșmāti", srov. huuntu ša eșmāti, revmatická horečka, revmatismus (Parpola et al. 2007, 38).

94 SAA X 242, 14 - rev. 10.
} 
že byl upoután na lư̌̌ko, nebot' Urad-Nanāia jinde cituje jeho stižnost, že o něho není postaráno jako o jeho královské předchůdce, protože „,jejich služebníci u nich seděli po všechny noci a nosili je na nosítkách". ${ }^{5}$ V závěru tohoto textu Urad-Nanāia píše: „Byliny, které králi posílám, jsou dvojiho druhu; jsou nazývány "dlouhá rostlina" $\left(\mathrm{U}_{2} \cdot \mathrm{GID}_{2}\right)$ a "hưl života” (U. $\cup_{2}$ PA.TI) a navzájem se liší. Ta, která vypadá jako základna náušnice, je důležitá a velmi vzácná. (...) Jsou dobré k ušburrudû (...). Posilám také mušallimānu. Mušallimānu [...] do postele [...] ${ }^{\prime 96}$

Povaha předmětu nazývaného mušallimānu ${ }^{97}$ je neznámá, snad se mohlo jednat o jakýsi amulet, který si měl král vložit do postele. Identifikovány dosud nebyly ani dvě zmíněné byliny, podle Parpoly by však první z nich by mohla být vzhledem k logogramu jakousi popínavou rostlinou ${ }^{98}$ Obě měly sloužit k rituálu proti očarování, ${ }^{99}$ který byl konán pravidelně v měsíci abu, ale pokud bylo potřeba, mohl být proveden i jindy, at už jako ochranný, k odvrácení zla, nebo pro léčebné účely. V tomto prípadě měl vyléčit chorobu, jejiž původ byl spatřován v černé magii. Zlá kouzla mohla způsobit napríklad bolest hlavy, cukání v tváŕi, bolest nosních dírek, slintání, zapomnětlivost, pálení vnitřností, ochrnutí paží, strnulost rukou, píchání v chodidlech či vratké kotníky. ${ }^{100}$ Vzhledem ke stižnostem na slabost v rukou a nohou a $k$ dalším potižím mohl král trpět většinou ze jmenovaných problémů.

Z Urad-Nanāiova pisátka pochází také značně poškozený seznam zdravotních potiží a prostředků k jejich léčbě SAA X 327. Vedle jiných neduhů je zde zmíněno ochrnutí, ${ }^{101}$ př́slušná pasáž s léčbou je však

${ }_{95}$ SAA X 316, 11-13.

${ }^{96}$ SAA X 316, rev. $15-$ r.e. 25.

${ }^{97}$ Mušallimānu, mistr, význam nejasný (CAD M $\mathrm{z}_{2}$, 256).

${ }^{98}$ Parpola 1983, 243; SAA X, 360. Geller názvy těchto rostlin přepisuje jako U2BU a U2Hatti a předpokládá, že Urad-Nanāia použil laickou terminologii, aby mu král rozuměl, či snad dokonce uvedl neexistujići názvy, aby zdưraznil vzácnost a uccinnost rostlin (Geller 2010, 80-81). V AHw je navř̌eno čtení obou termínů dohromady jako u2pu- u $_{2}$-pa-ti (AHw, 879; srov. CAD P, 511).

${ }_{99}$ Ušburrudû, rituály proti čaroděnictví (CAD U/W, 300). Viz téź Parpola 1983, 147 a 163-167.

100 Parpola 1983, 147.

101 Šimmatu, ochrnutí, ochromení (AHw, 1238). Parpola preedpokládá ochrnutí úst (Parpola 1983, 259). 
poškozena, ochrnutí levé a pravé paže, ${ }^{102}$ a ochrnutí úst či němota, ${ }^{103}$ která má být léčena „(rituálním) otíráním úst, mas[tí proti] ochrnutí [úst a rituály] proti ochrnu[tí ú]st". ${ }^{104}$ Ač je datace textu i jeho spojitost s Asarhaddonem nejistá, jmenované obtíže odpovídají vladařovu stavu popsanému v jiných textech. Parpola se domnívá, že může jít o seznam zaslaný králi spolu s některým dopisem. ${ }^{105}$

Král trpěl rovněž kožními obtižemi. Urad-Nanāia v jednom dopise píše o králově vyrážce ${ }^{106}$ a radí mu, aby se mazal ptačím tukem a myl si ruce ve vlažné vodě ${ }^{107}$ Tématem Urad-Nanāiova dopisu SAA X 325 je léčba skvrn na kưži, ${ }^{108}$ které mají být léčeny semeny rostliny kasû ${ }^{109}$ a žejejě také pravidelným omýváním úst vodou. ${ }^{110}$ Kožní potíže Asarhaddona snad potvrzuje i Issār-šumu-ēreš, který píše o jeho nemoci mangu. ${ }^{111}$ Termín mangu je překládán jako ochrnutí či ztuhnutí, ale také jako kožní choroba. ${ }^{112}$

Urad-Nanāia ve svém seznamu nemocí a léčiv píše také o masti na saharšubbû, snad lepru. ${ }^{113}$ Není jisté, že Asarhaddon trpěl právě tímto

102 SAA X 327, rev. 4-5. Viz Parpola 1983, 259.

103 Kadibbidû, němota (CAD K, 31), ochrnutí úst (AHw, 419).

104 SAA X 327, e. 1-2.

105 Parpola 1983, 258. Geller uvažuje o lékařově osobním seznamu léčiv pro obtǐzně léčitelné potíže (Geller 2010, 82).

106 Undū, kožní choroba (CAD U/W, 158), vyrážka (Parpola et al. 2007, 129). Parpola soudí, že pokrývala především královy ruce (Parpola 1983, 253), jinde však píše: „Jeho zjev byl patrně vážně zhyzděn kožní vyrážkou, pupeny a puchýři na rukou, nohou a pravděpodobně také na tvárii." (tamtéž, 234). Podle Radner (2003, 169) vyrážka postihla zvláště králův obličej.

107 SAA X 318, rev. 3 - r.e. 13. Viz též Parpola 1983, 253.

108 Pi'āru, nemoc (CAD B, 217), skvrna na kǔži (AHw, 124). Viz též Parpola 1983, 254-255.

${ }^{109}$ Kasû, aromatická rostlina se štiplavými semeny (CAD K, 248), zahradní rostlina, snad „řepa obecná“ (SAA X, 340), hořčice, Sinapis nigra (Parpola 1983, 255), hořčice (-zelí), Sinapis nigra (AHw, 455), kokotice (Parpola et al. 2007, 48).

110 SAA X 325, 11 - rev. $2^{\prime}$.

111 SAA X 37, rev. 1 a 7 . Viz Parpola 1983, 336-337.

112 Mangu, ztuhnutí, ochrnutí (CAD M, 211 ), kožní nemoc (AHw, 602), nemoc (SAAX, 345).

113 Saharšubbû, lepra (CAD S, 36), „pokrytí prachem”, lepra (AHw, 1005), záchvat (Geller 2010, 82). 
onemocněním, nicméně spojení králových kožních potiží se saharšubbû nastiňuje rovněž Radner, která uvádí, že právě proto se Asarhaddon zajímal o kult měsičního boha Sîna z Harrānu, který mohl nemoc saharšubbû způsobit. ${ }^{114}$

Svědění kůže ž̌ejmě souviselo také s královou vysokou horečkou, nebot si král stěžuje, že je poškrábaný. ${ }^{115}$ To nepř́mo potvrzuje také Urad-Nanāia, když králi spolu s jedním dopisem posílá vedle roztoku proti horečce také mast, jǐz se má potírat při akutních záchvatech nemoci. ${ }^{116}$ Ostatně i termín undū, překládaný jako vyrážka, někteří badatelé přepisují jako unțu a považují jej za variantu slova huunțu, horečka. ${ }^{117}$

Další z králových potiží byl zánět očí (bunț̦u ša ēnāte $\left.{ }^{118}\right)$, proti němuž navrhuje Marduk-šākin-šumi „provést (pravidelný) rituál měsíce ajaru proti zánětu [očí]."199 Potǐži s panovníkovýma očima se týká i text, v němž Ikkāru králi píše, že mu již třikrát posílal "masti, vykuřovací prostředky, ${ }^{120}$ amulety a léčivé nápoje ${ }^{121}$ “122 Přípravu léčivého nápoje pak nastiňuje neznámý lékař takto: „Jako jakýkoliv jiný léčivý nápoj, který můj pán pije, nakapeš hrotem pisátka tři kapky do nápojové misky a vypiješ to před chlebem. " 123 Masti a vykurovací prostředky pro krále zmiňuje ve velmi poškozeném dopise SAA X 250 Marduk-šākin-šumi, ${ }^{124}$ je ovšem otázkou, na jakou část panovníkova těla byly použity, protože prameny hovoří také o vykuřování králových uší.

Potiže s ušima dokumentují dva Urad-Nanāiovy dopisy, z nichž v prvním piše 0 zahájení léčby, ${ }^{125} 0$ léčivém nápoji a po mezeře způsobené

\footnotetext{
114 Radner 2003, 173.

115 SAA X 242, 9.

116 SAA X 315, r.e. 18-21. Viz též Parpola 1983, 229.

117 Např. Geller 2010, 82 a 188 pozn. 115. Srov. Parpola 1983, 253.

118 Např. Parpola et al. 2007, 38.

119 SAA X 243, rev. 2'-4'.

120 Outāru, vykuřovací prostředek (CAD 0, 321).

121 Mašqītu, lék, nápoj (CAD M, 382).

122 SAA X 328, 8-10.

123 SAA X 336, 1 - rev. 2.

124 SAA X 250, 8'-9'.

125 SAA X 324, 8-13.
} 
poškozením tabulky zmiňuje jakýsi kámen mūṣu. ${ }^{126} \mathrm{~V}$ druhém už léčbu přímo popisuje: „Oleje kanaktu' ${ }^{127}$ a nikiptu, ${ }^{128}$ které jsem poslal, by měly být nejdřive nakapány [do ucha], [poté] necht' provedou vyku[řování]. Jakmile dokonči vyku[řování], měli by (proceduru) zopakovat, nakapat [zbytek oleje] n[a chomáč červené viny ${ }^{129}$ a vložit jej] do ucha. [Je to] velmi [účinn]é. "130 Použití tampónu z viny jako nosiče léčiva bylo v mezopotamské medicíně běžné. ${ }^{131}$ Olej nikiptu byl podle terapeutických textů používán proti hučení v uších a krvácení z uší, zatímco olej kanaktu k odstranění ušního mazu a proti bolesti uší. ${ }^{132}$

Léčba potíží s ušima figuruje několikrát rovněž v Urad-Nanāiově seznamu nemocí a léčiv. V prvních dvou prípadech je záznam príliš poškozen, ve třetím se však píše „Mas[ti], vykuřovací prostředky, léčivé [nápoje] proti hučení v [uších], vykuřování má být doprovázeno zaklínáním [...]." ${ }^{\text {"133 }}$

Asarhaddonovy fyzické potíže byly provázeny také problémy psychickými. Astrologové Balasî a Nabû-aḩhēer-eríba píší o Asarhaddonově sklíčenosti a nechutenství, které trvá již třetí den. ${ }^{134}$ Také Adad-šumu-uṣur se krále starostlivě táže, proč již druhý den nejí a setrvává ve tmě, ${ }^{135}$ a radí: „[Jedení ch]leba a [pití v]ína [brzy od]straní [chorobu krále]. (...) Malomyslnost, nic nejíst a nepít rozrušuje mysl krále a napomáhá

\footnotetext{
${ }^{126}$ Mūșu, nemoc močových cest, kámen (CAD $\left.M_{2}, 246\right)$, složka léčivých přípravků (Parpola 1983, 244).

127 Kanaktu, strom, aromatická látka získávaná ze stromu (CAD K, 135), kadidlovník (AHw, 434), pryskyřici produkující rostlina nebo strom (Parpola 1983, 251).

128 Nikiptu, pryšec (Parpola et al. 2007, 77), rostlina (CAD N 2, 222), keř produkující pryskyřici, snad Euphorbia antiquorum L. (Parpola 1983, 251). Parpola uvádí, že se mu v medicínských textech nepodařilo dohledat zdroj tohoto léčebného postupu, ovšem oba oleje byly pro léčbu uší doporučovány ve stejném duchu, jako v tomto dopisu (nakapání přímo do uší, na tampón, vykuřování). Nikdy však nebyly jediným léčivem a byly kombinovány s dalšími substancemi (Parpola 1983, 250).

129 Tabrēbu, červená vina (CAD T, 30).

130 SAA X 323, 13 - rev. 9.Viz též Parpola 1983, 249-251.

131 Geller 2010, 84.

132 Parpola 1983, 250.

133 SAA X 327, rev. 13-16.

134 SAA X 43, 9 - rev. 11. Viz též Parpola 1983, 57-60.

135 SAA X 196, 14 - rev. 6.
} 
nemoci. "136 Také Urad-Nanāia naznačuje, že král propadal malomyslnosti a pocitu, že o něho není dobře postaráno. ${ }^{137}$ Králův žalostný psychický stav není nijak překvapivý, když si uvědomíme, že vedle četných neduhů byl vladař sklíčen také nedávným ${ }^{138}$ spiknutím, do něhož byli zapojeni i významní hodnostáři. ${ }^{139}$ Radner soudí, že svou roli hrála také smrt královny Ešarra-ḩammat ${ }^{140}$ začátkem roku 672 př. n. I. ${ }^{141}$

\section{Moderní pokusy o stanovení diagnózy}

Množství pramenů i Asarhaddonův historický význam občas svádějí ke snahám o stanovení jeho diagnózy. Zřejmě nejpodrobněji se této otázce věnoval S. Parpola, který se na základě dobových zpráv a konzultací s lékaři přiklonil k diagnóze systémový lupus erythematodes (lupus erythematosus disseminatus), ${ }^{142}$ což je onemocnění pojivové tkáně neznámého, pravděpodobně autoimunitního původu. ${ }^{143}$ Svůj závěr ovšem považuje za prozatímní a nevylučuje, že by mohlo jít o onemocnění jiné. ${ }^{144}$

Tento návrh byl některými badateli prímo ${ }^{145}$ či s určitou dávkou pochybností přijat. ${ }^{146}$ Jiní poněkud opatrněji soudí, že se "Asarhaddon mohl narodit $s$ nějakým druhem genetické poruchy", 147 nebo že "vykazoval

${ }_{136}$ SAA X 196, rev. 10 - r.e. 18. Viz též Parpola 1983, 129.

137 SAA X 316, 7-13.

138 Parpola 1983, 238. Viz též Radner 2003. Nedávné odhalení spiknutí potvrzuje rovněž text SAA X 316 (srov. Geller 2010, 79-80 a Parpola 1983, 238nn).

139 "Jedenáctý (rok Asarhaddona): v Asýrii dal král usmrtit mnoho svých hodnostárư. " (Grayson 1975, 86).

140 Radner 2003, 169. Král jí vystrojil honosný pohřeb (SAA X 233, SAA X 234; Parpola 1983, 190-191, 194-195) a postavil mauzoleum (Borger 1956, 10).

141 „Osmý rok Asarhaddona. (...) Pátého dne měsíce addaru zemřela králova žena." (Grayson 1975, 84-85).

142 Parpola 1983, 232.

143 Leven 2004, 380.

144 Parpola 1983, 232.

145 Kaiser 1996, 30-36.

146 Radner 1998, 146. Jinde však Radner uvádí, že „není zcela jasné, zda neduživý Asarhaddon prodělal jedno onemocnění za druhým, nebo, jak se zdá pravděpodobnějšś, trpěl nápory chronické nemoci, která se nikdy nevyléčila“"(Radner 2003, 169).

147 Leichty 2011, 2. 
symptomy chronického oslabujicího onemocněni”, 188 prípadně že „patrně trpěl nějakou kožní nemocí."149 Podle M. Roth by v úvahu mohly připadat i jiné diagnózy, zvláště Reiterův syndrom. ${ }^{150}$ Geller zase uvádí, že Asarhaddon "trpěl rưznými chronickými chorobami".151 Ostře proti Parpolovým závěrům vystoupil K.-H. Leven. Parpolova hypotéza podle něho stojí na pochybném předpokladu, že jsou všechny popsané symptomy projevem jedné choroby a že zprávy jmenují všechny hlavní př́znaky, zatímco ty nedůležité neobsahují vủbec. Dále uvádí, že lupus erythematodes byl poprvé identifikován až na začátku 19. století a i dnes je pro stanovení této diagnózy potřeba laboratorního vybavení. ${ }^{152}$ Své hodnocení Leven uzavírá: „Dobře zdokumentovaný př́pad Asarhaddona, který by měl být analyzován v kontextu asyrské medicíny a kultury, je takto omezen na základní popis nemoci lupus erythematodes." 153

\section{Shrnutí}

Závěrem tedy lze tedy konstatovat, že otázka použitá v názvu článku zůstává stále nezodpovězena. Domnívám se, že tomu tak žejmě i zůstane a že určení presné panovníkovy diagnózy z hlediska moderní medicíny není vzhledem k povaze a množství pramenů možné. Zprávy, které máme k dispozici, jsou často vlivem poškození tabulek útržkovité, jejich datace je nezř́́dka jen príbližná a zdaleka není jisté, zda máme k dispozici kompletní soubor textů. A i kdybychom jej měli, nevíme, zda tyto zprávy skutečně obsahují všechny důležité informace, nebo zda naopak nejsou některé údaje zveličeny. Dalším úskalím je terminologie používaná pisateli dopisů. Překlady některých termínů se rozcházejí, proto je někdy určení potiží i metod léčby nejisté a mnoho léčivých substancí nelze s jistotou identifikovat.

\footnotetext{
148 Melville 1999, 22.

149 Pečírková 2000, 89.

150 Frame 1992, 92.

151 Geller 2010, 81.

152 Leven 2004, 372-373, 380-381.

153 Leven 2004, 382.
} 
Asarhaddon se žrejmě opravdu již od mládí netěšil dobrému zdraví, jak naznačuji některé texty, veškeré podrobnější a jednoznačnější prameny však pocházejí až z posledních let jeho vlády. Je tedy otázkou, zda jej podobné obtiže postihovaly již dřive a skutečně se jednalo o vážné chronické onemocnění s nepravidelně se opakujícími záchvaty, nebo zda se panovníkovo zdraví rapidně zhoršilo až ke konci jeho života, snad i vlivem událostí v jeho soukromém i veřejném životě.

Roku 670 př. n. I. se Asarhaddon sice ještě zotavil, podle jedné babylónské kroniky však byla nemoc nakonec príčinou jeho smrti během válečného tažení do Egypta o rok později. 154 $^{24}$

154 „Dvanáctý rok: král Asýrie táhl do Egypta, (ale) onemocněl na cestě a zemřel 10. dne měsíce marhešvanu. "(Grayson 1975, 86). 


\section{Literatura}

AHw $=$ von Soden, Wolfram. 1965. Akkadisches Handwörterbuch. Wiesbaden: Harrassowitz.

Borger, Rykle. 1956. Die Inschriften Asarhaddons, Königs von Assyrien. Graz: Im Selbstverlage des Herausgebers.

CAD = Oppenheim, A. Leo, Erica Reiner a Martha T. Roth (vyd.). 1956-2010. The Assyrian Dictionary of the Oriental Institute of the University of Chicago. Chicago: Oriental Institute of the University of Chicago.

Douek, Ellis. 2007. „Ancient and Contemporary Management in a Disease of Unknown Aetiology." In Disease in Babylonia, vyd. Irving L. Finkel a Markham J. Geller, 215-218. Leiden - Boston: Brill.

Frame, Grant. 1992. Babylonia 689-627 B.C.: A Political History. Istanbul: Nederlands Historisch-Archaeologisch Instituut te Istanbul.

Geller, Markham J. 2010. Ancient Babylonian Medicine: Theory and Practice. Chichester - Malden: Wiley-Blackwell a John Wiley \& Sons.

Grayson, Albert Kirk. 1975. Assyrian and Babylonian Chronicles. Locust Valley, New York: J. J. Augustin.

Kaiser, Otto. 1996. „Arzt und Patient: Der Fall des Asarhaddon, Königs von Assyrien." Medizin, Gesellschaft und Geschichte 14: 9-36.

Leichty, Erle. 2011. The Royal Inscriptions of Esarhaddon, King of Assyria (680-669 BC). Winona Lake, Indiana: Eisenbrauns.

Leven, Karl-Heinz. 2004. „At Times these Ancient Facts Seem to Lie before me like a Patient on a Hospital Bed" - Retrospective Diagnosis and Ancient Medical History." In Magic and Rationality in Ancient Near Eastern and Graeco-Roman Medicine, vyd. Marten Stol a H. F. J. Horstmanshoff, 369-386. Leiden - Boston: Brill.

Melville, Sarah C. 1999. The Role of Naqia/Zakutu in Sargonid Politics. Helsinki: Neo-Assyrian Text Corpus Project.

Millard, Alan Ralph. 1994. The Eponyms of the Assyrian Empire 910-612 BC. Helsinki: Neo-Assyrian Text Corpus Project. 
Parpola, Simo. 1970. Letters from Assyrian Scholars to the Kings Esarhaddon and Assurbanipal, Part I. Kevelaer - Neukirchen-Vluyn: Butzon \& Bercker - Neukirchener Verlag.

Parpola, Simo. 1980. „The Murder of Sennacherib." In Death in Mesopotamia, vyd. Bendt Alster, 171-182. Copenhagen: Akademisk forlag.

Parpola, Simo. 1983. Letters from Assyrian Scholars to the Kings Esarhaddon and Assurbanipal, Part II. Kevelaer - Neukirchen-Vluyn: Butzon \& Bercker - Neukirchener Verlag.

Parpola, Simo, Robert M. Whiting, Zack Cherry et al. (vyd.). 2007. Assyrian-English-Assyrian Dictionary. Helsinki: Neo-Assyrian Text Corpus Project.

Pečírková, Jana. 2000. Asýrie, od městského státu k říši. Praha: Academia.

Radner, Karen (vyd.). 1998. The Prosopography of the Neo-Assyrian Empire: A. Helsinki: Neo-Assyrian Text Corpus Project.

Radner, Karen. 2003. „The Trials of Esarhaddon: The Conspiracy of 670 B.C." Isimu 6: 165-184.

SAA IV = Starr, Ivan. 1990. Queries to the Sungod. Helsinki: Helsinki University Press.

SAA VI = Kwasman, Theodore a Simo Parpola. 1991. Legal Transactions of the Royal Court of Nineveh, Part I. Helsinki: Helsinki University Press.

SAA VIII = Hunger, Hermann. 1992. Astrological Reports to Assyrian Kings. Helsinki: Helsinki University Press.

SAA X = Parpola, Simo. 1993. Letters from Assyrian and Babylonian Scholars. Helsinki: Helsinki University Press.

SAAo = Tinney, Steve, Eleanor Robson a Niek Veldhuis. 2012. State Archives of Assyria Online, Philadelphia. http://oracc.museum. upenn.edu/saao/corpus [26. 4. 2016]. 


\section{David Rafael Moulis}

\section{Základové oběti v Kanaánu - olejové lampy s miskou a rituální pohřbívání oslů}

\section{Funkce základových obětí}

Tento příspěvek se věnuje rituálnímu vkládání depozitů pod podlahy budov, nebo k jejím zdem poblíž stavebních základů v oblasti starověkého Kanaánu. Takovéto zástavy můžeme právem označit za základové oběti. Ovšem ne vždy bylo obětováno zvî̃e, nebo dokonce člověk. Ukládání věcí pod podlahy staveb je staré jako stavitelství samo. Cílem aktivity byla ochrana objektu, a především jeho obyvatel. S jevem se běžně setkáváme při archeologických výzkumech starověkých měst Předního východu, ale i ve středověké Evropě. Příkladem z pozdější doby může být slovanské hradiště nad dnešním Starým Plzencem, kde byly odkryty pozůstatky několika kostelů. V základech kostela svatého Křriže byla nalezena dětská stavební obět. ${ }^{155}$ Obdobná praxe krvavého základového obětování je doloženu u Keltů v bavorském Manchingu a v oppidu ve Starém Hradisku na Moravě. ${ }^{156}$ Přestože my dnes žádné magické předměty do základů nedáváme, jistou souvislost je možné spatřit v tradici pokládání základních kamenů. Slavnostní poklepání na základní kámen, který může být posvěcen, je symbolickým aktem, jenž zaručuje úspěšné dokončení stavebních prací a ochraňuje novou budovu. Slavnostní zahájení se dnes týká jen vybraných veřejných staveb, a nikoliv běžných lidských obydlí, jako tomu bylo ve starověku.

155 Friedl 1920, 7

156 Škávová 2010, 63. 


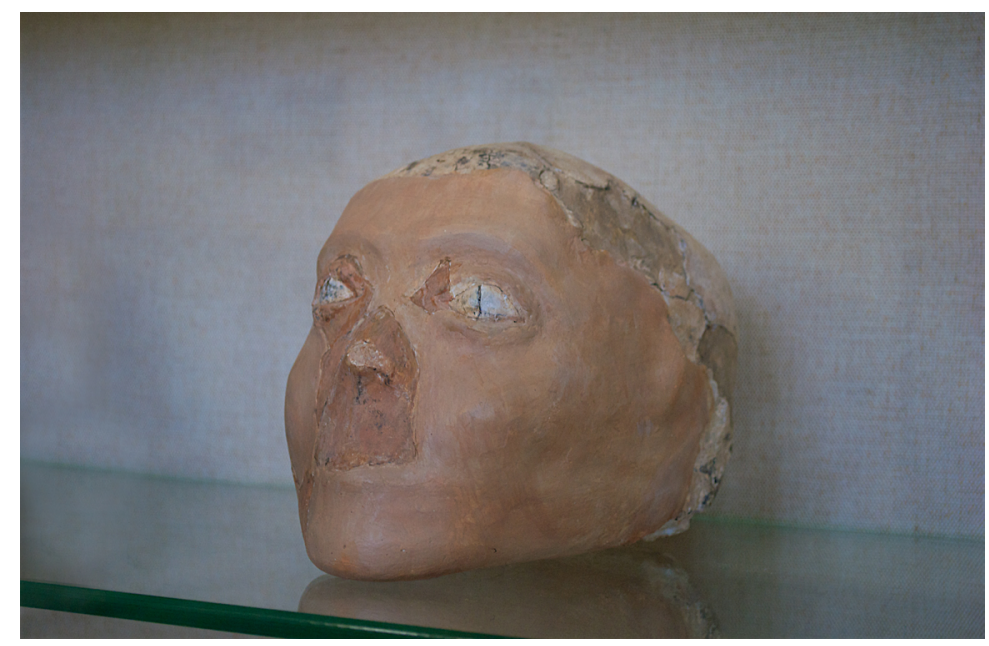

Obrázek č. 1. Jedna z domodelovaných lebek z Jericha, Rockefellerovo muzeum v Jeruzalémě (foto autor)

Nejstarší ukládání objektů životného charakteru pod podlahy domů se poprvé objevilo v období neolitu ve městech, jako je Jericho, Ajn Ghazal nebo Ammán. Nejednalo se o obětování živých členů rodiny, nýbrž některým zemřelým předkům byla oddělena lebka, která byla domodelována hlínou, a místo očí byly dány mušle. Nakonec byla hlava natřena tělovou barvou (obr. č. 1). Skutečný účel tohoto rituálu nám není dodnes zcela znám, přesto se z nálezů dá vyvodit skutečnost, že zemřelý byl i po své smrti neustále prítomen ve své rodině (v rodu či klanu) a tak ji ochraňoval. Domodelované lebky jsou jedním z prvních uměleckých projevů v oblasti a zároveň i známkou rané náboženské aktivity spojené s kultem předků během 8.-7. tisíciletí př. Kr. ${ }^{157}$ Oproti základovým obětem nebyly domodelované lebky zpravidla ukládány pod podlahy domů během jejich výstavby, ale až dodatečně poté, co předek zemřel a až když jeho ostatky byly bez tkání. Tento rituál tedy nebyl spojen se zakládáním budovy, ale už v něm můžeme spatřit snahu o ochranu místa, která je spojena s uctíváním předků.

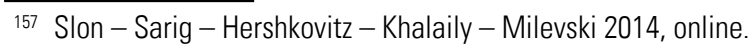


Není tajemstvím, že od nejstarších dob byli obětováni lidé a k obřadu se užívala rovněž zvir̃ata, keramické nádoby nebo jiné magické předměty. Záměrné ukládání do základů nebo do zdí domů se muselo uskutečnit na počátku zahájení stavby a to tak, aby byla kultovními praktikami zajištěna její príznivá budoucnost a ochrana. ${ }^{158}$

Obět označuje náboženské rituální jednání, prì němž je živý obětní dar či hmotný předmět zasvěcen božstvu, duchům nebo jiným neviditelným silám. Obětovaný předmět má „donutit” bytost ke splnění přání nebo ke smî̃ení a symbolickým poděkováním má být zabráněno jakékoliv pohromě. Za odevzdaný dar byla očekávána protislužba ve formě ochrany obydlí. ${ }^{159}$

Protože se tento text zaměřuje na dobu bronzovou na Předním východě, budou zde prezentovány dvě typické podoby základových obětí. Tou první jsou keramické nádoby (především olejové lampy a keramické misky, tzv. misky s lampou) a druhou formou je pohřbívání oslů pod podlahy domů, které jsou spojeny s určitou ekonomicky aktivní vrstvou.

\section{Olejová lampa v keramické misce (miska s lampou)}

Od pozdní doby bronzové až do mladší doby železné se v Šefele v západním Negevu a na severním Sinaji objevoval druh základové oběti, která je nejčastěji tvořena lampou mezi dvěma miskami. $\checkmark$ jedné misce byla lampa uložena a druhou, dnem vzhůru, byla přikryta (obr. č. 2 a 3). Někdy se v těsné blízkosti nacházely další misky a kalichy jako napríklad v Gezeru, kde bylo nalezeno více jak patnáct takových depozitů a kde vždy byla miska s lampou tvořena kombinací dvou až sedmi keramických nádob. ${ }^{160} \mathrm{Na}$ některých lokalitách misky obsahovaly zeminu či popel. Otevřenou otázkou zůstává, jak velkou pozornost je materiálu v nádobách poť̌eba věnovat, protože se do misek mohl dostat sekundárně mnohem později a s rituálem nemusel mít nic společného. Přesto se Petrie snažil nalézt vysvětlení

158 Gardelková 2009, 7.

159 Murrer - Elser - Ewald 1997, 247.

160 Macalister 1912, 435-436. 


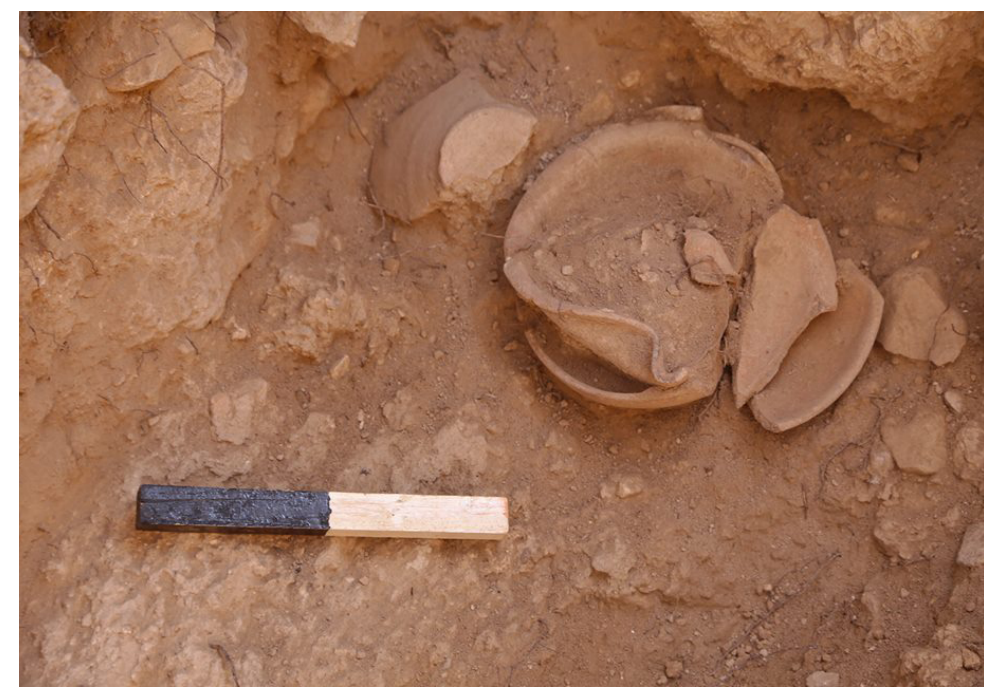

Obrázek č. 2. "Lampa s miskou“ z lokality Tel Azeka, (https://www.facebook.com/LautenschlaegerAzekahExpedition/ photos, náhled 8. 5. 2016)

v paralele v Egyptě, kde byl do nejniže uložené nádoby $\mathrm{k}$ základům nového objektu dáván písek. ${ }^{161}$ Výpůjčka zvyku z Egypta v Kanaánu není nikterak podložena a proto $v$ úvahu přichází, že se materiál do misek mohl dostat napríklad při násilném zničení místa po jeho následném vypálení nebo při běžné přestavbě budovy.

Žádný ze zmíněných keramických předmětů nevykazuje známky předchozího používání, což je patrné především na absenci sazí u olejových lamp v místech, kam se dával knot. Typologicky se jedná o předměty každodenní potřeby a nejsou mezi nimi neobvyklé nádoby. Velmi často je nález učiněn blízko základů zdí u nejspodnějšího kamene, ale také v rozích místností, nebo pod prahem. ${ }^{162}$ Většina základových vkladů

\footnotetext{
161 Petrie, 1928, 7-8.

162 Poloha misky s lampou pomáhá určit půdorys a umístění prahu či rohů místnosti budov, které byly později odstraněny, ale základové zástavy zůstaly nedotčeny in situ.
} 


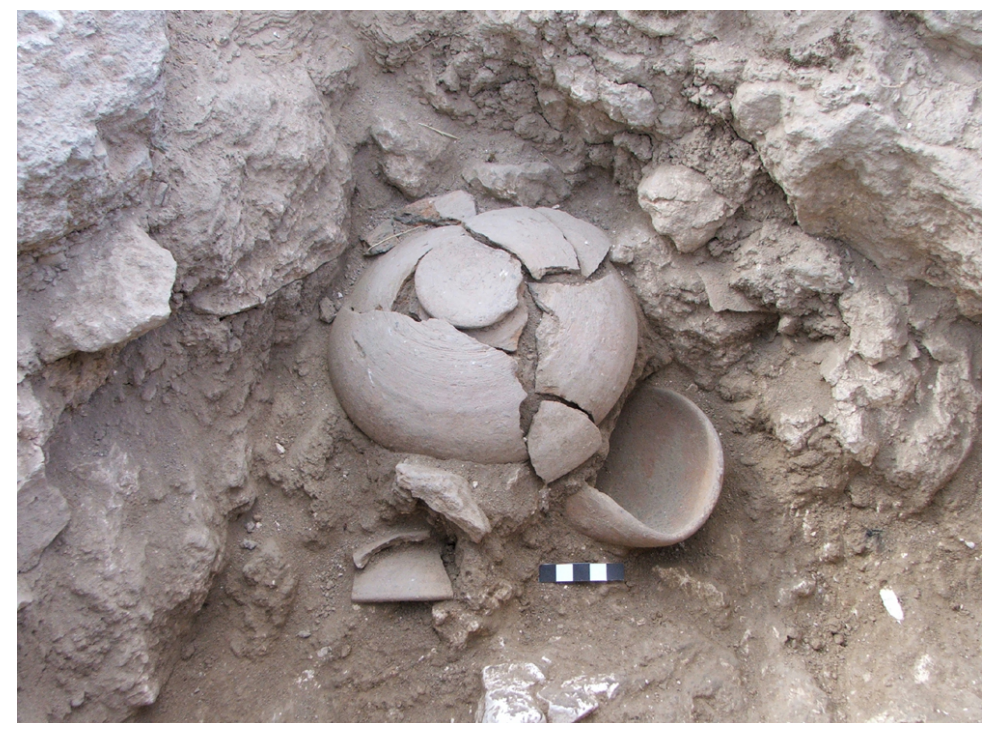

Obrázek č. 3. Základový depozit z lokality Gat/Tell es-Safi (https://gath.wordpress.com/2006/03/01/the-weekly-findlamp-and-bowl-deposits/, náhled 8. 5. 2016)

pochází z tehdejšího jižního Kanaánu (např. z Lakíše, ${ }^{163}$ Gezeru, ${ }^{164}$ Bet Šemeše, ${ }^{165}$ Afeku, ${ }^{166}$ Gatu, ${ }^{167}$ Deir el-Bala, ${ }^{168}$ Tel Azeky' ${ }^{169}$ aj.) a objevují se u různých druhů staveb (u chrámů, domu guvernéra, v egyptské pevnosti i v běžných domech). ${ }^{170}$ Rituál se objevoval především ve městech, kde se nacházely egyptské pevnosti, nebo v místech, kde byl ž̌ejmý egyptský vliv v průběhu vlády 19. a 20. dynastie. ${ }^{171}$ Tato skutečnost

\footnotetext{
163 Bliss - Macalister - Wunsch 1902, 151-152.

164 Macalister 1912, 434-436.

165 Grant 1931, 49.

166 Beck - Kochavi 1985, 29-42.

167 Greenfield - Shai - Maeir 2012, 26-27.

168 Dothan - Nahmias-Lotan 2010, 111-114.

${ }^{169}$ Bliss - Macalister - Wunsch 1902, 151-152; The Lautenschläger Azekah Expedition, online.

170 Bunimovitz - Zimhoni 1993, 99-121.

171 Bunimovitz - Zimhoni 1993, 122.
} 
ovlivnila interpretaci zvyku jako původní egyptskou tradici. Na druhou stranu je pozoruhodné, že v Bet Šeánu, kde byla př́tomna egyptská posádka, nebyla vykopána žádná zástava tohoto typu. To mohlo být způsobeno tím, že si dřive badatelé misek s lampou nepovšimli nebo jim nevěnovali pozornost. Bunimovitz a Zimhoniová vychází při interpretaci z novějších poznatků, a proto se domnívají, že obřad byl přijat pod vlivem egyptské nadvlády v oblasti Kanaánu v pozdní době bronzové. Vkládání základových obětí bylo známo z Egypta už z dob Staré říše ${ }^{172}$ a do Kanaánu proniklo společně s dalšími kulturními aspekty (pohřbívání do hliněných sarkofágů v Bet Šeánu a Deir el Bala, uctívání egyptských božstev a imitování razítkových pečetítek). Samotné provádění rituálu s hliněnou miskou a lampou je lokální kanaánskou záležitostí, která mohla být součástí většího obřadu, jenž mohl být doplněn dalšími aktivitami jako například hudebním doprovodem, o němž nám archeologie nic nevypovídá.

V posledních letech se objevují názory, že tento typ základových obětí mohl v Kanaánu vzniknout nezávisle na okolních kulturách. ${ }^{173}$ V Egyptě, tak jako už dřive v Mezopotámii (základové kolíky), byly přidávány depozity do základů staveb, ale není možné doložit přímý egyptský vliv na místní kanaánský zvyk. Důvodem takového závěru je absence podobných nálezů misky s lampou v Egyptě.

Archeologové Bliss a Macalister spojovali tyto uložené keramické nádoby se starším rituálem obětí novorozeňat během zakládání staveb. ${ }^{174}$ Původně se u zdí volně ukládala těla kojenců. Později se jejich ostatky umistovaly do speciálních schránek a až když bylo od této praxe upuštěno, symbolika obětní praxe se promítla do zmiňovaných keramických objektů. Lampa symbolicky zastupovala oheň a miska, která byla nepropustná, měla schopnost udržet původně krev, v tomto případě víno nebo štávu z hroznů jako náhražku životadárné tekutiny. Proto je možné uvažovat nad faktem, že do misky byla skutečně během

\footnotetext{
172 Více k základovým depozitům v Egyptě viz Weinstein 1973, Foundation Deposits in Ancient Egypt.

173 DePietro, 2012, 120-121.

174 Macalister 1912, 434.
} 
obřadu tekutina nalévána, a naopak mưžeme vyloučit to, že by do misky byla během rituálu dávána hlína či popel. DePietro na základě pozorování polohy depozitu došel k závěru, že v mnohých prípadech byla miska s lampou na své místo uložena až po zahájení výstavby. Své tvrzení opírá o skutečnost, že se depozit nenachází pod samotnými zdmi budovy, ale je uložen vedle nich, a proto navrhuje odebrat z označení depozitu slovo základový. ${ }^{175}$ At' už byla miska s lampou do objektu umístěna v jakékoliv fázi výstavby, není pochyb o tom, že rituál byl skutečně provázán se stavební aktivitou. Protože se také depozit keramiky nalézá v nejnižší možné části budovy u základů, je ho podle autora článku možné i nadále nazývat základovým depozitem.

\section{Rituální pohřbívání oslů}

Podobnou funkci jakési základové zástavy plnili obětovaní domestikovaní osli, kteří byli ukládáni pod podlahy budov, poblǐ̌ lidských hrobů či u svatyní. K domestikaci osla nubijského došlo na konci období chalkolitu v oblasti severovýchodní Afriky. Všude, kde se v mladší době bronzové objevil tento domestikovaný druh, můžeme doložit výrazné kulturně sociální změny, které by do té doby byly zcela nemožné. Ze zvî̃ete bylo využíváno maso, kosti, kǔže, krev, mléko, srst a také hnůj..$^{176}$ Avšak největší př́nos osla byl především v jeho tažné síle a schopnosti uvézt těžký náklad včetně osob. Toto využití je z území Kanaánu doloženo nálezy hliněných sošek oslíků s přivázanými nádobami na přepravu vody a dražších komodit. ${ }^{177}$ Osel rovněž patřil společně s ovcemi, kozami a holuby ke zvir̃atům, která byla obětována při náboženských obřadech. Osel byl zvir̃etem, které mělo ve starověkém předovýchodním kultu výjimečný status. Otázkou zůstává, proč je rituálně pohřbíván právě osel? Odpovědí mohou být následující rádky, ze kterých vyplývá, pro jaké sociální skupiny byl osel důležitý v každodenním životě. Svoji roli hrál u válečníkủ a vážených jedincủ, jakými byli obchodníci a majitelé oslü,

\footnotetext{
175 DePietro, 2012, 120-123.

176 Greenfield - Shai - Maeir 2012, 23.

177 Ke známému nálezu patří malé oslí sošky z Aradu, které ukazují na to, jak byla do města dopravována voda. Aharoni, Arad: Its inscriptions and Temple, 6-7.
} 
kteři měli po rozkvětu mezinárodního obchodu své výsostné sociální postavení, a to se rovněž promítlo do pohřební ideologie této elity.

Z raného 3. tisíciletí př. n. I. pocházejí nejstarší nálezy pohřbených oslů z egyptských lokalit Abúsír ${ }^{178}$ nebo Abýdos. ${ }^{179} \mathrm{~V}$ hrobech byly někdy uloženy ostatky lidí, či jiných zvir̃at a tyto nálezy je možné spojovat s tehdejší elitou. ${ }^{180}$

$\checkmark$ polovině téhož tisíciletí se fenomén objevuje i na dalších místech starověkého Předního východu, z nichž za zmínku stojí napríklad Kiš, ${ }^{181}$ Lagaš, ${ }^{182} \mathrm{Ur}^{183}$ a Tel Brak. ${ }^{184}$ Na poslední zmiňované lokalitě se některé kostry oslů objevují mimo kontext, a proto je těžké určit jejich původní význam, i když je známo, že se často jedná o symbolické doprovázení zemřelého člověka tažným zvir̃etem - oslem na jeho poslední cestě. Objevy v Egyptě pobliž hřbitovů také nasvědčuji obětní praxi spojené $s$ bohem Setem (Sutechem). ${ }^{185} \mathrm{~V}$ hrobech s osly, které jsou i nadále vázány na elitu, jsou na Předním východě v této době nově nacházeny napřiklad předměty spojené $s$ tažnými zvî̃aty. ${ }^{186} \mathrm{~V}$ oblasti dnešního Izraele byly odkryty kompletní kostry oslů v izolovaných hrobech na nalezištích Tel Lod či Gat/Tel es-Safí. Absence kontextu neumožňuje přesně určit, zda se jednalo o část rituálu (napřílad pohřebního), nebo o tradiční obětování zvî̃ete. Z rané doby bronzové pochází další kompletní nález oslí kostry z Tel es-Sakanu nedaleko Gazy, kde byl osel pochován u zdi pod podlahou v obytné čtvrti. ${ }^{187}$

V průběhu střední doby bronzové ve 2. tisíciletí př. Kr. se tradice stává velmi oblíbenou v Egyptě a Kanaánu. Díky vzrưstajícímu počtu nálezů z tohoto období je mǔžeme dávat do souvislosti s kultickými aktivitami,

\footnotetext{
178 Boessneck - Eissa, 1992, 1-10.

179 Rossel, 2008, 3715-3720.

180 Way, 2010, 211.

181 Gibson, 1972, 85, 310.

182 Hansen, 1973, 62-70.

183 Littauer - Crouwel, 1979, 24-40.

184 Emberling - McDonald, 2003, 48-49.

185 Greenfield - Shai - Maeir 2012, 25.

186 Way, 2010, 211.

187 Greenfield - Shai - Maeir 2012, 26.
} 


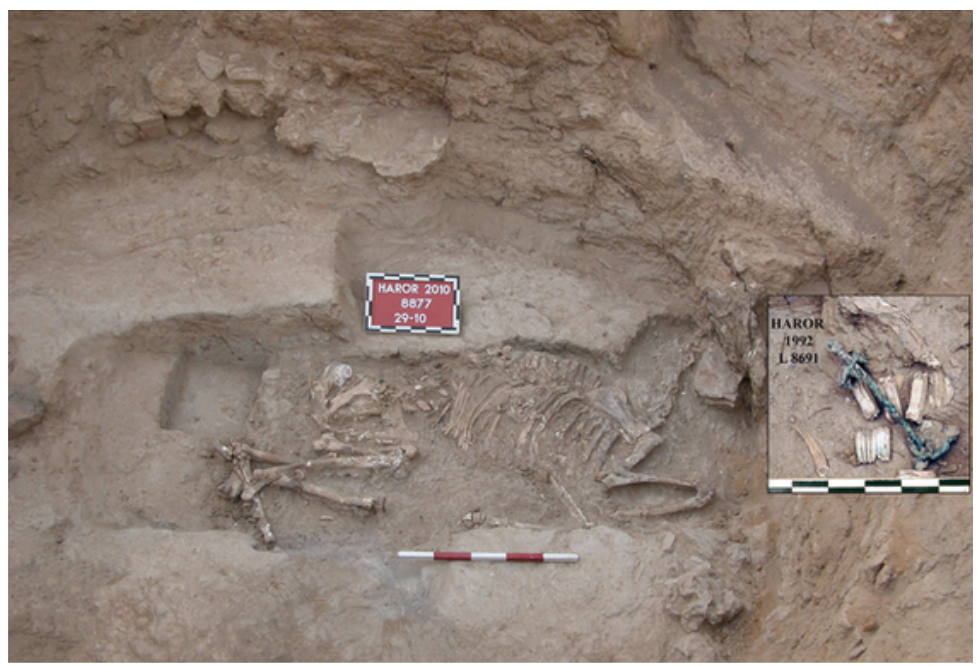

Obrázek č. 4. Rituálně pohřbený osel na lokalitě Tel Haror (http://www.livescience.com/27767-sacrificed-donkey-grave-found.html, náhled 8. 5. 2016)

tak jako na izraelské lokalitě Tel Haror, kde byl osel rituálně uložen ve speciálně vybudovaném místě v posvátném okrsku poblíž chrámu. Osel měl na hlavě položené koňské udidlo a na zádech zbytky přepravní brašny, která se dávala na sedlo (obr. č. 4). Neobvyklá je kombinace koňského udidla (prvku užívaného u koní k tažení vozíků) a brašny, ve které osli nosili náklad. Netradiční spojení artefaktů se zde objevuje v jasném náboženském kontextu a představuje důležitost koňovitých na starověkém Předním východě. ${ }^{188}$ Jelikož u udidla chyběly ostatní součásti, které tvoří celou uzdu, jíž by se dal osel ovládat, a jeho zuby nejevily žádné známky po poničení udidlem, Ize konstatovat, že předmět byl uložen skutečně jen jako symbol. Mimo to bylo zjištěno, že osel byl natolik mladý, že ještě neměl dostatek síly, aby mohl být tažným zvir̃etem. ${ }^{189}$

188 Bar-Oz - Nashoni - Motro - Oren 2013, 1.

189 Bar-Oz - Nashoni - Motro - Oren 2013, 2-3. 
Stále častěji je ve 2. tisíciletí př. Kr. pohřbívání oslů spojeno s veřejnými monumentálními stavbami. V oblasti dnešního Izraele tento zvyk přetrvává nejdéle ze všech tehdejších předovíchodních kultur. Pokud bylo zvir̃e uloženo v budově, stalo se tak pod podlahou centrální místnosti, u chrámového komplexu, nebo jako základový depozit u zdí, či v rohu místnosti. ${ }^{190}$ Napríklad v egyptském městě Avaris, někdejším centru Hyksósů (dnes Tell el-Dab'a), byl ve vrstvě z období vlády 13. století př. Kr. odkryt jeden z největších chrámů střední doby bronzové. Byl natřen modrou barvou, což naznačuje, že byl zasvěcen kosmickému božstvu. Ve dvou jámách před svatyní byly objeveny páry oslü. Na této lokalitě se nejedná o nikterak výjimečný nález. Páry kompletních oslích koster jsou zde častým doplňkem pohřbených mužů. ${ }^{191}$ Tito muži mohli být bud' válečníky, obchodníky, nebo lidmi spojenými s chodem svatyní, které byly provázány s osly, jak bude popsáno dále.

Z archeologických nálezů se dozvídáme o bohaté obchodní síti, která byla obsluhována oslími karavanami např́č Levantou a Anatolií. Obdobně tomu bylo v Egyptě, kde se osli používali k přepravě materiálu Z dolů. Z toho vyplývá vysoké sociální postavení starověkých oslařů čili obchodníkủ anebo samotných vlastníků. V mladší době bronzové se objevují kromě zvî̃ecích pozůstatků také keramické sošky ztvárnuující osly. Jsou nacházeny v náboženském či rituálním kontextu a též u sdružených obchodníků, kteří tvořili jakýsi cech na konci rané doby bronzové. ${ }^{192}$ Oslí figuríny, někdy s kontejnery na zádech, byly s největší pravděpodobností soukromými kultickými predměty obchodníků či lidí, kteři měli co do činění s obchodem. Sošky kolovaly mezi členy tohoto společenství, avšak nebyly předmětem běžného obchodu (obr. č. 5). ${ }^{193}$ Podobný jev můžeme vidět již v Eble (z 3. tisíciletí pr. Kr.) a Ugaritu (z 2. tisíciletí př. Kr.), kde nám jsou známy početné skupiny obchodníků. Jejich aktivita byla provázána s existencí kultu spojeného s osly. Jednalo se o zcela odlišnou skupinu obyvatel s jinými sociálními vlastnostmi, než jaké měl zbytek populace. To bylo způsobeno jejich

\footnotetext{
190 Way, 2010, 211.

191 Forstner-Müller, online.

192 Milevski 2009, 133.

193 Milevski 2009, 136.
} 


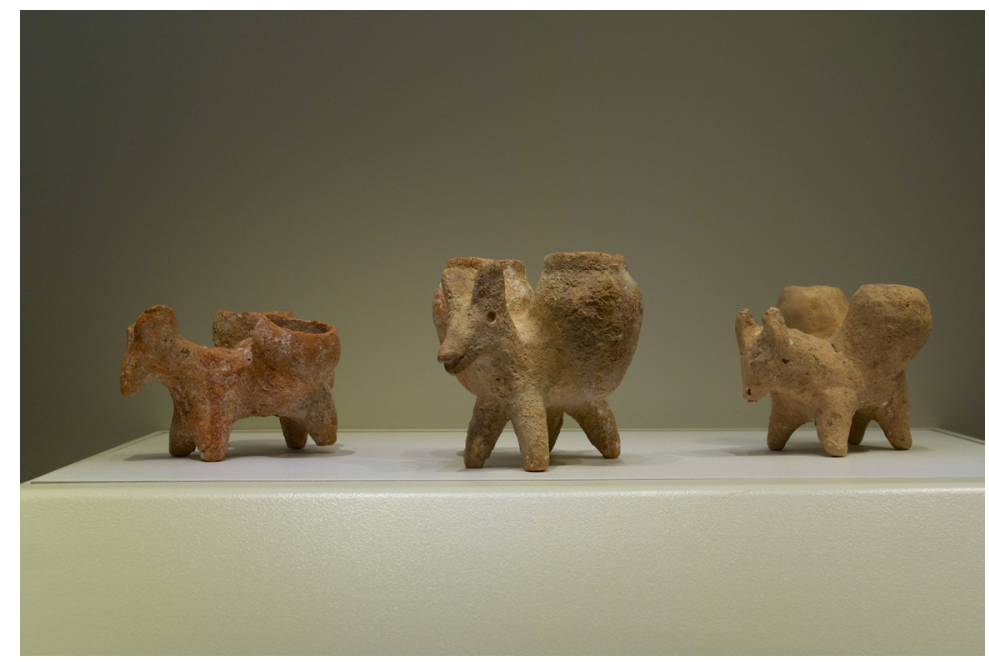

Obrázek č. 5. Sošky nalezené na území Kanaánu z doby bronzové, Izraelské muzeum v Jeruzalémě (foto autor)

výraznou ekonomickou aktivitou. ${ }^{194} \mathrm{~V}$ mladší době bronzové existovala série chrámů na pobřeží Kanaánu a také v Jordánském údolí či v údolí Arava. Svatyně na obchodních stezkách byly zapojeny do dovozu nejrưznějších komodit ze zahraničí i z blízkého okolí a sloužily jako místa, odkud se zboží prodávalo a rozváželo dále. Božstvo, kterému byl chrám zasvěcen, ochraňovalo obchodníky a jejich aktivity. Ikonografické nálezy sošek oslů a pečetí nám poodhalují, že motiv osla skutečně reprezentoval obchod. Z nalezených předmětů Ize prokázat, že různé skupiny (ekonomické, sociální a politické) nebo konkrétní společenské role byly symbolizovány konkrétními zvir̃aty. ${ }^{195}$ Osel se stal kulticky významným zvî̃etem i z toho důvodu, že dopravoval předměty nutné k rituálním úkonům v chrámech. V Sýrii a Anatolii převážel vozíky s obrazy či sochami božstev při procesích. Obdobně byl v Tel Haroru osel použit k rituálu, jehož součástí byla hostina, nebot se nad kostrou nalezlo množství kostí z ovcí a koz. Avšak obětovaný osel zde

194 Milevski 2009, 137.

195 Milevski 2009, 138. 
jako potrava nesloužil, protože kosti nenesou známky po odřezávání masa. ${ }^{196}$

Osel, jako jediné nekošer zvî̃e, hrál svoji roli v judském kultu, kde se dozvídáme o jeho obětování, konkrétně prvorozeného samce ve Starém zákoně toto:

„Samci z každého prvního vrhu tvého dobytka patři Hospodinu. Každého osla otvírajicího lưno však vyplatís jehnětem; kdybys ho nemohl vyplatit, zlomís mu vaz. Rovněž každého prvorozeného ze svých synů vyplatîs. " ${ }^{\prime 197}$

Na území dnešního Izraele archeologové vzácně, ale stále častěji objevují pod podlahami budov pohřbené osly z mladší doby bronzové. Kompletní pozůstatky pocházejí napríklad z již zmíněných míst Tel Lod (nález učiněn mimo kontext), Tel es-Sakanu v Gaze (zvir̃e bylo pochováno v obytné čtvrti pod zdí), z Gatu a Tel Azeky (kostra byla pod podlahou domu)..$^{198}$ Kosterních nálezů oslů je mnohem více, než bylo doposud publikováno, ale dřive jim nebyla věnována taková pozornost jako $v$ dnešní době, nebo se jednalo o objevy mimo jakýkoliv žrejmý kontext, čímž je ztí̌ena jeho interpretace.

Jeden ze zatím nejlépe popsaných nálezů toho typu byl učiněn v Gatu $\checkmark$ roce 2008. V rohu místnosti byla skryta kompletní kostra osla. Podle uložení kostí se dá určit, zda bylo zvir̃e jen tak vhozeno do odpadní jámy, nebo zda bylo pečlivě uloženo podle rituálních pravidel. Poškození kostí mưže napovědět, jakým způsobem bylo zvir̃e usmrceno. Jáma, ve které je zvî̃e v Gatu položeno, přesně kopíruje jeho pưvodní tvar před rozkladem tkáně, z čehož Ize usoudit, že prostor byl vytvořen pod podlahou domu za zcela jasným účelem těsně po obětování zvî̃ete. Oslu nechyběly zuby, ani jiné kosti, jeho hlava byla orientována na východ, ohnuté nohy naznačuji, že zviře je mělo všechny čty̌ri svázané a do jámy bylo uloženo po smrti. Prozkoumání kostry prokázalo, že mladá oslice

\footnotetext{
196 Bar-Oz - Nashoni - Motro - Oren 2013, 5.

197 Ex 13,12-13.

198 Way 2010, 211. Autor příspěvku je členem archeologického týmu, který Tel Azeku odkrývá. Viz The Lautenschläger Azekah Expedition, online.
} 
nebyla usmrcena při lovu, ani nezemřela přirozeně, naopak byla předpisově obětována a byla jí věnována náležitá pozornost. ${ }^{199}$ Oslice byla pohřbena jako základová obět pod dům při prestavbě čtvrti v mladší době bronzové. Při oné přiležitosti se konal rituál, jehož cílem bylo, aby $\checkmark$ budoucnu byla čtvrt i její obyvatelé ochráněni. Osel pro ně byl kulticky významným zvir̃etem. Proto je dost pravděpodobné, že těmito osobami byli lidé, kteři byli zapojeni do obchodu a do přepravy zboží. ${ }^{200}$

Jen několik kilometrů od Gatu leži jiná archeologická lokalita - Tel Azeka. Na severní straně telu byli v roce 2012 nalezeni dva pohřbení osli. Jelikož se jedná o poměrně čerstvý nález, ještě nebyly provedeny veškeré analýzy. Jisté je, že i zde byl nález kostry skryt pod podlahou domu z mladší doby bronzové a že se rovněž jednalo o rituální pohřeb. ${ }^{201}$ Nachází se v blízkosti chrámu z doby bronzové. Prozatím nebyly publikovány výsledky z této zkoumané oblasti telu, a proto nám ještě není znám vztah mezi jednotlivými objekty (domem a chrámem) a pohřbenými osly.

Posledním obdobím, kdy je možné vypozorovat vztah oslích hrobů s veřejnými či monumentálními stavbami (napríklad v Lakíši a Jerichu), je střední doba bronzová, kdy lze hovořit i o úpadku zvyku pohřbívání oslů pobliž lidských hrobů. V době železné osel zůstává pouhým symbolem elity a to jen na území Judska a Izraele. ${ }^{202}$

\section{Závěrem}

Nálezy misek s lampou jsou spojeny s rituálem při zakládání staveb v Kanaánu. Jednalo se o symbolické nahrazení obětí kojenců humánnějšími praktikami. Pưvodně se předpokládalo, že přerod egyptského zvyku v jeho kanaánské pojetí proběhl na konci doby bronzové, nyní se badatelé prikiání k názoru, že přímý egyptský vliv není prokazatelný a zvyk se stal v Kanaánu velmi rozšî̃eným jevem bez cizího kulturního

199 Greenfield - Shai - Maeir 2012, 35-37.

200 Greenfield - Shai - Maeir 2012, 26-27 a 44.

201 The Lautenschläger Azekah Expedition, online.

202 Greenfield - Shai - Maeir 2012, 26-27, Way 2010, 211, Greenfield - Shai - Maeir 2012, 25. 
vlivu. Popularitu dokazují desítky nálezů olejových lamp mezi miskami u základů zdí, prahů vě̌ejných budov (domů guvernéra, chrámů, egyptské pevnosti) i v soukromých domech. Více detailů o tom, jak přesně rituál probíhal, kdo jej vykonával a komu konkrétně bylo obětováno, není zatím možné zjistit. Přesto mǔžeme dojít k závěru, že se jednalo o velmi rozšrî̃ený rituál, který je doložen desítkami nálezư v konkrétním kontextu - zakládání nových budov a rituálu, který stavební aktivitu doprovázel.

Druhou, mnohem starší a již méně rozšî̃enou variantou, jak ochránit stavbu, či její obyvatele, bylo obětování a následné rituální pohřbívání oslů. To je možné rozdělit do pěti základních skupin:

1. hrob osla souvisí s lidským hrobem (mohlo se jednat o prestiž, nebo socio-ekonomický status; osel také mohl symbolicky doprovázet jedince na jeho poslední cestě po smrti)

2. hrob osla je bez vazby na lidské hroby (tyto pozůstatky jsou dokladem zvir̃ecích obětin)

3. pohřbení osli u zdí budov (typické pro celou Levantu, jedná se o základový depozit, který byl součástí rituálu, při němž bylo zvî̃e obětováno)

4. hroby oslů v chrámech (zvir̃e bylo obětováno pro božstvo, jemuž byla svatyně zasvěcena)

5. velké hroby u chrámů (zvir̃ata, nejen osli byli obětováni při uzavirání smluv). ${ }^{203}$

Jelikož byl osel symbolem určité sociální skupiny lidí, kteří byli spjati s obchodem a přepravou zboží a osob, je možné tyto nálezy spojovat s jejich obydlím anebo s chrámy, které se aktivně zabývaly obchodem a stávaly pobliž obchodních cest v době bronzové. Oba dva typy základového depozitu byly spojeny s výstavbou nových budov a zajištovaly jejich budoucí ochranu. Rituální obětování a pohřbívání oslů je jev, který zaniká v pozdní době bronzové, a naopak se v tomto období začínají objevovat lampy s miskou, jejichž tradice se vyskytuje až do počátku doby železné.

${ }^{203}$ Way 2010, 212-215. 


\section{Literatura}

Aharoni, Yohanan. 1968. „Arad: Its Inscriptions and Temple.” Biblical Archaeologist 21: 2-32.

Beck, Pirhya a Moshe Kochavi.1985. „A Dated Assemblage of the Late 13th Century BCE from the Egyptian Residency at Aphek." Tel Aviv 12: 29-42.

Bible: překlad 21. století. Přeložil Alexandr Flek a kol. 2009. Praha: Biblion.

Bliss, Frederick Jones, Robert Alexander Stewart Macalister a Richard Wunsch.1902. Excavations in Palestine During the Years 1898-1900. London: Committee of the Palestine Exploration Fund.

Boessneck, von den Driesch, Angela a Ahmed Eissa. 1992. „Eine Eselsbestattung der 1. Dynastie in Abusir." Mitteilungen des Deutschen archäologischen Instituts Abteilung Kairo 48: 1-10.

Bunimovitz, Shlomo a Orna Zimhoni. 1993. „Lamp and Bowl Foundation Deposits in Canaan." Israel Exploration Journal 43: 99-121.

DePietro, Dana Douglas. 2012. Piety, Practice, and Politics: Agency and Ritual in the Late Bronze Age Southern Levant. Disertační práce. University of California, Berkeley.

Dothan, Trude a Tamar Nahmias-Lotan. 2010. „A Lamp and Bowl Deposit." In Deir el-Balah: Excavations in 1977-1982 in the Cemetery and Settlement 2010, vol. II: The Finds (Qedem 50), vyd. Trude Dothan a Baruch Brandl, 111-114. Jerusalem: Hebrew University.

Emberling, Geoff a Helen McDonald. 2003. „Excavations at Tell Brak 2001-2002: preliminary report." Iraq 65: 1-75.

Friedl, Antonín. Nálezová zpráva čj. 3816/39. Archiv ARÚ AV ČR, Praha. Gardelková, Anna. 2009. Pohřby lidských jedinců v prostorách neolitických staveb. Bakalárská práce. Filozofická fakulta Masarykovy univerzity, Brno.

Gibson, McGuire. 1972. The City and Area of Kish. Miami: Field Research Projects. 
Grant, Elihu. 1931. Rumeileh: Being Ain Shems Excavations, vol. I (Biblical and Kindred Studies). Haverford, Pennsylvania: Haverford College.

Greenfield, Haskel, J., Itzhaq Shai a Aren Maeir. 2012. „Being an „ass": An Early Bronze Age Burial of a donkey from Tell es-Safi/Gath, Israel." Bioarchaeology of the Near East 6:21: 21-52.

Hansen, Donald, P. 1973. „Al-Hiba, 1970-1971: a preliminary report.” Artibus Asiae 35: 62-70.

Littauer, Mary Aiken a Joost H. Crouwel. 1979. Wheeled Vehicles and Ridden Animals in the Ancient Near East. Leiden: Brill.

Macalister, Robert Alexander Stewart. 1912. The Excavation of Gezer 1902-1905 and 1907-1909, vol. II. London: Published for the Committee of the Palestine Exploration Fund by J. Murray.

Milevski, lanir. 2009. „Local Exchange in the Southern Levant during the Early Bronze Age: a Political economy viewpoint, in Antiguo Oriente." Cuadernos del Centro de Estudios de Historia del Antiguo Oriente 7: 124-159.

Murrer, G., M. Elser a S. Ewald. 1997. Encyklopedie náboženství. Kostelní Vydří: Karmelitánské nakladatelství.

Petrie, William Flinders. 1928. Gerar. London: British School of Archaeology in Egypt.

Rossel, Stine et al. 2008. „Domestication of the donkey: timing, processes, and indicators." Proceedings of the National Academy of Sciences 10:105, 3715-3720.

Škávová, Miroslava. 2010. Lidská obět'a její význam a role v náboženství. Bakalárská práce. Fakulta filozofická, Univerzita Pardubice.

Way, Kenneth, C. 2010. „Assesing Sacred Asses: Bronze Age Donkey Burials in the Near East." Levant 2:42, 210-225.

\section{Internetové zdroje}

Bar-Oz, Guy, Pirhiya Nashoni, Hadas Motro a Eliezer D. Oren. 2013. „Symbolic Metal Bit and Saddlebag Fastening in a Middle Bronze 
Age Donkey Burial." PLOS ONE 8:3, dostupné z: http://journals.plos. org/plosone/article?id=10.1371/journal.pone.0058648, náhled 21. 1. 2016.

Forstner-Müller, Irene. Area A/II: Late 12th Dynasty until the End of the Second Intermediate Period: Tell el-Daba, oficiální stránky projektu, dostupné z: www.auaris.at/html/areal_a2_en.html, náhled 27. 4. 2016.

The Lautenschläger Azekah Expedition, oficiální facebookové stránky projektu, dostupné z: https://www.facebook.com/LautenschlaegerAzekahExpedition/posts/645621175484092, náhled 26. 1. 2016.

Slon, Viviane, Rachel Sarig, Israel Hershkovitz, Hamoudi Khalaily a lanir Milevski. 2014. The Plastered Skulls from the Pre-Pottery Neolithic $B$ Site of Yiftahel (Israel) - A Computed Tomography-Based Analysis, dostupné z: http://journals.plos.org/plosone/article?id=10.1371/ journal.pone.0089242, náhled 12. 1. 2016. 


\section{Katarína Šomodiová}

\section{Mandejci včera a dnes ${ }^{204}$}

Klúčové slová: Mandejci, blízkovýchodní imigranti v Európe, náboženské minority v Iraku, náboženské minority v Iráne

Problematika náboženských a etnických menšín Blízkeho východu je vzhl'adom na prebiehajúcu násilnú homogenizáciu regiónu vysoko aktuálnou témou. V západnom diskurze sú čoraz častejšie polemiky na tému ohrozenia a prípadnej záchrany blízkovýchodných krestanov, židov či jezídov, ako aj aktívna politika prijímania vojnových utečencov na základe konfesijnej príslušnosti (ako príklad môžeme uviest́ prípady prijatia irackých krestanov na Slovensku v decembri 2015 a v Českej republike v januári a februári 2016, resp. verejné zbierky konané v USA špecificky na relokácie krestanských rodín do tretích, bezpečných krajín. ${ }^{205} \mathrm{~V}$ rámci týchto diskusií sa pre odbornú aj laickú verejnost' stávajú dostupnejšie informácie o osobitostiach východného krestanstva a iných, viac či menej špecificky blízkovýchodných náboženských systémov. Podla názoru autorky tohto príspevku však stále nie je venovaný dostatočný priestor prezentácii Mandejcov, ${ }^{206}$ unikátnej

204 Tento príspevok vznikol na Katedre porovnávacej religionistiky FiF Univerzity Komenského s podporou grantov VEGA 1/0050/14 a Grantu pre doktorandov a mladých vedeckých pracovníkov Univerzity Komenského UK/540/2015.

${ }^{205}$ Pre bližšie informácie o týchto akciách, ich pozadí, priebehu a financovaní pozri napríklad dokumentárny film Escaping ISIS 20/20: Iraqi Christian Refugees Escape ISIS dostupný online na https://www.youtube.com/watch?v=hjiafK61NPE alebo Šomodiová 2016, 13-21.

206 Pri diskusiách o Mandejcoch v slovenskom a českom jazyku sa autorka relatívne 
blízkovýchodnej náboženskej skupiny, ktorá takmer dve tisícročia prispievala k pestrému konfesijnému koloritu Mezopotámie a momentálne na území Iránu prechádza komplexnou transformáciou a v Iraku čelí vážnej hrozbe vyhladenia.

Cielom tohto príspevku je preto priblǐizit a porovnat základné charakteristiky mandejskej vierouky a ich implementáciu do rituálnej praxe ako v domácom prostredí v iránskom Chúzestáne, kde ešte žije početnáa7 pôvodná mandejská komunita, tak v diaspóre, konkrétne v Nemecku a Dánsku. Text sa vo vel'kej miere opiera o zistenia z terénneho výskumu Katedry porovnávacej religionistiky FiF Univerzity Komenského v Ahváze v októbri $2015^{208}$ a autorkin terénny výskum medzi Mandejcami v okolí Mníchova a v severnom Dánsku v novembri a decembri 2015.

\section{Kto sú Mandejci}

Formulácia exaktnej definície mandeizmu a Mandejcov ako takých je zložitejšia, než by sa na prvý pohl'ad mohlo zdat'. Môže za to nejasná raná história, množstvo externých vplyvov, ktorým boli komunity a vierouka počas stáročí koexistencie s inými náboženskými systémami $\checkmark$ jednom geografickom prostredí vystavené, ako aj nejednoznačná etnická, a do určitej miery aj občianska, identita veriacich.

Posledné necelé dve miléniá je domovom Mandejcov oblast Mezopotámie, teda východný Irak a juhozápadný Irán. Nie je úplne jasné, odkial' pôvodne pochádzali, väčšina bádatel'ov sa však zhoduje na tzv. teórii západného pôvodu Mandejcov, t. j. na hypotéze, že prapôvodnou

často stretáva s otázkou, či výraz „Mandejci“ písat' s vel'kým alebo malým začiatočným písmenom. Exaktná odpoved' neexistuje, kedže nie je jednoznačne možné definovat', či ide o výlučne náboženskú, alebo náboženskú a zároveň etnickú skupinu. Ako bude vysvetlené nižšie, Mandejcov Iránu je možné charakterizovat́ ako etnicko-náboženskú skupinu, pokým v prípade irackých Mandejcov ide skôr o čisto náboženskú skupinu. Vzhl'adom na to, že tento príspevok pojednáva o Mandejcoch Iraku aj Iránu, autorka sa rozhodla používat' označenie s vel'kým začiatočným písmenom.

207 Vzhladom na absenciu oficiálnych štatistických údajov nie je možné exaktne určit počet Mandejcov žijúcich v Ahváze resp. v Iráne.

${ }^{208}$ Terénny výskum bol realizovaný v rámci projektu VEGA 1/0050/14 s titulom „Rudolf Macúch a náboženské minority v Iráne". 
vlastou Mandejcov je oblast' Palestíny. Tento predpoklad podopierajú predovšetkým lingvistické analýzy (výrazy ako jardna - voda, odvodené pravdepodobne od názvu rieky Jordán, alebo kušta- pravda) a sledovanie zretel'ných vieroučných paralel so židovskými gnostickými sektami, ktoré v regióne v tomto období pôsobili (napr. dôraz na múdrost' resp. vedomie, odmietanie materiálneho bohatstva, dualizmus). ${ }^{209}$

Nie je jasné, kedy došlo k migrácii Mandejcov do Mezopotámie, je však isté, že v období islámskej expanzie už existovali kodifikované mandejské posvätné texty, vd'aka čomu im bol udelený status ahl al-kitáb. V Koráne sú opakovane spomínaní ako Sabejci (aș-Ṣabi'ún, aș-Șubba):

Věru ti, kdož uvěřili, a ti, kdož jsou židy, křestáany a sabejci , ti, kdož uvěřili v Boha a v den soudný a konali zbožné skutky - ti naleznou odměnu u Pána svého a nemusí mít strach a nebudou zarmouceni.

Korán 2:62

Věru ti, kdož uvěřili, a ti, kdož vyznávají židovství, a sabejci a křestané - vủbec ti, kdož uvěrili v Boha a v den poslední a dobré skutky konali, ti nemusí mít strach a nebudou zarmouceni.

Korán 5:69

A věru ti, kdož uvěrili a ti, kdož vyznávají židovství, sabejci, křestané a zoroastrovci a ti, kdo k Bohu prídružují, zjistí, že Bůh mezi nimi rozliší v den zmrtvýchvstání, nebot' Bůh svědkem je všech věcí.

Korán 22:17

Po väčšinu obdobia pod islámskou vládou mohli teda výmenou za platenie džizje v pokoji pestovat' svoje náboženské presvedčenie a rituály. ${ }^{210}$ Napríklad v období osmanskej nadvlády im bolo umožnené

\footnotetext{
209 Pre bližšie informácie o pôvode Mandejcov pozri napríklad Jacobsen Buckley 2002, 3-6 alebo Gebelt 2008, 33-34.

210 Samozrejme, v priebehu dejín sa príležitostne objavili konflikty medzi Mandejcami a inými zložkami populácie. Môžeme spomenút masaker mandejskej komunity príslušníkmi majoritnej arabskej populácie v regióne Džazíra v 14. storočí. (Drower 1937, 14.) Zo 16. storočia sú tiež zaznamenané prípady nútenej násilnej konverzie Mandejcov na krestanskú vieru Portugalcami, ktorí mali v Basre obchodnú stanicu (ibid., 15).
} 
vyhnút sa povinnej vojenskej službe zaplatením určitého poplatku, ked'že mandejská vierouka sa stavia proti používaniu zbraní a fyzickému boju. ${ }^{211}$

Mandejci sa typicky živili ako zlatníci a klenotníci a dodnes relevantná čast zlatníctiev v Ahváze patrí Mandejcom. Tým si zabezpečili pomerne dôležitú a vysoko cenenú funkciu v rámci širšej spoločenskej štruktúry a úctu resp. minimálne indiferenciu majoritnej populácie.

K relatívnemu pokoju a rešpektu zo strany vládnej moci aj majoritnej populácie vo vel'kej miere prispela aj absencia politických, resp. mocenských ambícií Mandejcov. Samotná vierouka aj individuálne komunity veriacich sú úplne apolitické, preto nikdy nepredstavovali pre aktuálnu vládnu moc reálnu hrozbu. Ako istú formu odmeny za túto lojalitu im jednotlivé vládne režimy väčšinou bez problémov umožňovali pokojné praktizovanie viery.

Moderné dejiny Mandejcov sú však plné výziev. V tridsiatych rokoch 19. storočia komunitu postihla epidémia moru, ktorej okrem relevantnej časti laikov podlahla aj drvivá väčšina kňazov. Vzhl'adom na to, že väčšina mandejských rituálov si vyžaduje prítomnost́ kňaza, bola vážne ohrozená náboženská prax a tým pádom aj existencia samotnej komunity. Vdaka vzdelaným laikom sa podarilo náboženský život obce zachránit', ale vytvorenie novej kňažskej vrstvy trvalo desatročia a je možné predpokladat', že sa stratila značná čast tradície, ktorá bola dovtedy odovzdávaná orálne. Jedným z dôsledkov týchto udalostí bol rapídny nárast písomností týkajúcich sa detailov vierouky a vysvetlení k rituálom. Autormi boli bud’ vzdelaní laici alebo kňazi a boli určené kňazom a/alebo laickým veriacim, prípadne nemandejskej verejnosti, v snahe zachovat autentickú mandejskú vieroučnú tradíciu a sprostredkovat jej poznanie ako príslušníkom komunity, tak majoritnej populácie. ${ }^{212}$

211 Ibidem.

212 Gebelt 2008, 34-35. 


\section{Vierouka a sväté písma}

Hlavné vieroučné princípy mandeizmu boli zhrnuté v knihe Ginza ${ }^{213}$ (Poklad), resp. Ginza Rabba (Najväčší poklad) niekedy medzi 2. a 7. storočím. Z tohto dôvodu sú Mandejci radení v Koráne medzi ahl al-kitáb. Najstaršie písomné pamiatky v mandejčine pochádzajú z 2.-3. storočia. Sú to jednak útržky modlitebných kníh, jednak rituálne misy obsahujúce náboženské texty. ${ }^{14}$ Vzhl'adom na to, že sa nezachoval žiaden z pôvodných prepisov Ginzy, o konkrétnom čase a okolnostiach jej spísania môžeme len polemizovat́.

Ginzu tvoria dve časti: Pravá a L'avá Ginza.

Pravá Ginza sa zaoberá rôznymi aspektmi viery a života mandejskej komunity. Obsahuje napríklad príbehy stvorenia sveta a dejín Mandejcov, ako aj etické a morálne predpisy.

Lavá Ginza predstavuje mandejskú koncepciu posmrtného života. Opisuje napríklad príbeh smrti Adama, ktorého mandeizmus považuje za prvého proroka, a obsahuje žalmy, ktoré sa recitujú na pohreboch a spomienkach na zosnulých. Tieto žalmy sú pravdepodobne silne ovplyvnené manichejskými žalmami. ${ }^{215}$

Ginza je tradične prepisovaná zásadne manuálne. Dodnes je jej ručný prepis jednou z dôležitých úloh kňazov.

Okrem Ginzy disponujú Mandejci prekvapivým množstvom d’alších náboženských písomností.

Klúčový význam má modlitebná kniha Qolastá. Je zbierkou modlitieb a spevov pre jednotlivé náboženské rituály, ako aj krstných liturgií. Jednotlivé časti pochádzajú z rôznych období a nie je možné spolahlivo určit, kedy boli prvýkrát zozbierané v dnes známej forme.

K významu knihy Qolastá prispieva aj to, že okrem samotných modlitieb obsahuje aj exaktné opisy jednotlivých rituálov, ktorým prináležia (napríklad svadobné či pohrebné rituály alebo rituál zasvätenia kňaza).

\footnotetext{
${ }^{213}$ V Európe po prvýkrát vychádza v roku 1925 v preklade Marka Lidzbarského. Pozri Lidzbarski 1925.

214 Podrobnejšie Gebelt 1996, 39-40.

215 Ibidem.
} 
Obsahuje tiež astrologický kalendár, v ktorom sú vyznačené obdobia vhodné pre realizáciu jednotlivých rituálov. Je teda mimoriadne významným dokumentom pre mandejských kňazov, ako aj laických veriacich.

Ďalšou esenciálnou knihou mandeizmu je Draša d-Jahjá, Kniha Jána Krstitelia. Je známa aj pod názvom Draša d-malikia, čiže Kniha králov. Predstavuje životopisy a diela Jána Krstitela, jeho súčasníkov a nasledovníkov. Ponúka teda cenný pohlad do dejín Mandejcov, hoci jej autenticita je otázna.

Mandeizmus dalej disponuje širokou škálou spisov zaoberajúcich sa eschatológiou, kozmológiou a astrológiou, ako aj praktickými aspektmi každodenného života. Môžeme spomenút napríklad spis Díwán Abatur, ${ }^{216}$ ktorý opisuje putovanie duše jednotlivými častami záhrobia až k Velkému Abaturovi, strážcovi „rišse svetla".

Dôležitý je tiež spis Hárán Gawaita, ktorý opisuje putovanie istej skupiny nazorejcov z Palestíny do "Vnútorného Haránu“. Je síce otázne, či túto skupinu skutočne predstavujú Mandejci, samotný význam tohto spisu v mandejskej tradícii však podporuje teóriu západného pôvodu Mandejcov. ${ }^{217}$

Mandejská tradícia dalej disponuje vel'kým množstvom komentárov spísaných pre kňazov a vzdelaných laikov. Ich počet výrazne narástol po epidémii moru v tridsiatych rokoch 19. storočia, ked'sa komunity snažili písomne dokumentovat časti tradície a ich interpretácie, ktoré boli dovtedy predávané ústne.

Samotné náboženstvo je komplexný gnostický monoteistický systém, v ktorom môžeme pozorovat' aj prvky náboženstiev abrahámovskej tradície, zoroastrizmu a manicheizmu.

Je silne dualistické, kladie napríklad zvy̌šený dôraz na dichotómiu dobra a zla, zeme a nebies, svetla a tmy či tela a duše. Dualitu ilustruje

${ }^{216}$ Prvý preklad Díwán Abatur do európskeho jazyka vypracovala Lady Drower. Pozri Drower 1950.

217 Aj s týmto spisom sa môže západný čitatel' zoznámit́ v preklade Lady Drower. Pozri Drower 1953. 
napríklad esencialita kontinuálneho konfliktu Ríše svetla a Ríše tmy $v$ mandejskej vierouke. ${ }^{218}$

V otázke pôvodu l'udstva vychádza mandeizmus zo židovskej tradície a gnostických mýtov, ktoré interpretujú silne dualistickým spôsobom: Prvým človekom na Zemi bol Adam. Jeho telo vzniklo v Ríši tmy. Naopak, jeho duša, primárna životodarná substancia, pochádza z Ríše svetla.

Mandejské náboženstvo sa vyznačuje výraznou ritualitou. Je možné predpokladat', že dôraz na časté, periodické a kolektívne rituálne praktiky sa vyvinul z potreby upevnenia skupinovej náboženskej identity Mandejcov v prostredí, kde dlhodobo tvorili málopočetnú minoritu a ich identita teda bola vystavená kontinuálnej hrozbe eliminácie. ${ }^{219}$ Rituály zdôrazňujú duševnú a telesnú čistotu, podobne, ako je to v prípade iných blízkovýchodných náboženských systémov. ${ }^{220}$

Najznámejším rituálom je krst - mașbuta. Práve vd’aka mașbute získali Mandejci relatívne rozšírené označenie „sabejci“, čiže krstitelia. Krst by mal byt' realizovaný v rieke každú nedelu, pri príležitosti významných náboženských sviatkov (napríklad oslavy Nového roka) a pred prechodovými rituálmi (napríklad uzavretie sobáša). Význam „živej“, čiže tečúcej vody je vysvetl'ovaný tým, že podl'a mandejskej tradície pramení každá rieka v Ríši svetla a samotný Adam bol pokrstený v rieke. Toto presvedčenie môže do istej miery vysvetlit fakt, že klúčovou osobnostou mandejskej tradície je Ján Krstitel', pričom Ježiša a viacerých iných prorokov abrahámovskej tradície mandeizmus odmieta.

Samotný krst otvára cestu do Ríše svetla, bez neho je vykúpenie duše po telesnej smrti vylúčené.

Pri mașbute musí byt prítomný aspoň jeden kňaz. Veriaci sa v bielom rituálnom odeve trikrát ponorí do rieky, potom mu kňaz trikrát pretrie čelo vodou rieky a recituje pritom príslušné verše z Ginzy resp. Oolasty. Potom sa veriaci trikrát napije z vody rieky. Na brehu kňaz pretrie čelo krsteného olejom a podá mu kúsok chleba. ${ }^{221}$

\footnotetext{
218 Pre bližšie informácie pozri Arabestani 2010 alebo Gebelt 2010.

219 Arabestani 2010, 2-3; Arabestani 2012, 6.

220 Pre bližšie informácie pozri Arabestani 2012.

221 Pre bližšie informácie pozri Drower 1937, 100-123 alebo Gebelt 2009.
} 
V prípade väčších sviatkov nasledujú po mașbute d'alšie rituály.

Druhým najdôležitejším mandejským rituálom je masiqta, čiže séria rituálov sprevádzajúcich umieranie a pochovávanie. Ciel'om je zaistit telesnú a duševnú čistotu umierajúceho a ulahčit mu tak vstup do Ríše svetla. Následne pokračuje masiqta tri dni po smrti veriaceho spoločnými modlitbami, omšou a stravovaním za zosnulého.

Dualitu vierouky a dôraz na telesnú a duševnú čistotu podčiarkujú aj stravovacie predpisy. Je zakázaná konzumácia väčšiny druhov mäsa, kedže zvieratá žijú na nečistej zemi a stravujú sa mäsom iných zvierat. Je povolená konzumácia rýb a hydiny (okrem dravcov), kedz̃e voda a vzduch sú považované za čisté. Rovnako je povolená väčšina druhov zeleniny, ovocia a obilia. Je pozoruhodné, že nie je zakázaná konzumácia baraniny.

Mandejská etika v mnohom pripomína etické princípy judaizmu, krestanstva a gnosticizmu. Jej dôležitými prvkami sú monogamia a endogamia. Mandejská vierouka odmieta materiálne bohatstvo a zakazuje napríklad rozvod manželstva či konzumáciu alkoholu.

\section{Jazyk a etnicita}

Mandejci bývajú charakterizovaní ako náboženská resp. etnicko-náboženská skupina, hoci ani jedna z týchto definícií nie je stopercentne výstižná.

Všetky sväté písma mandeizmu boli spísané v tzv. klasickej mandejčine, ktorú radíme medzi východoaramejské jazyky. Je teda blízkym príbuzným napríklad sýrčiny a asýrčiny. Klasická mandejčina je dodnes liturgickým jazykom Mandejcov. Je používaná pri všetkých náboženských rituáloch a jej, minimálne pasívna, znalost je základným predpokladom porozumenia základných vieroučných princípov mandeizmu, hoci sa relevantná čast veriacich pri štúdiu vlastného náboženstva opiera skôr o rôzne preklady Ginzy a iných textov do západných jazykov a arabčiny.

Moderná mandejčina má viacero dialektov, ale následkom emigrácie mandejských komunít z väčšiny Chúzestánu počas iracko-iránskej 
vojny nájdeme v súčasnosti jedinú homogénnu a organizovanú skupinu hovoriacich v meste Ahváz. Hoci si zachováva základné gramatické črty klasickej mandejčiny, jej slovná zásoba je silne ovplyvnená inými regionálnymi jazykmi, najmä perzštinou, a vzhl'adom na dlhodobo izolovaný vývoj nie je zrozumitel'ná pre tých, ktorí hovoria inými modernými východoaramejskými resp. novoaramejskými jazykmi.222

Z hl'adiska výskumu moderných Mandejcov je vel'mi dôležitý fakt, že Mandejci pochádzajúci z Iraku bežne nepoužívajú klasickú mandejčinu ani žiaden moderný dialekt a na každodennú komunikáciu využívajú lokálne dialekty irackej hovorovej arabčiny. Sami seba neidentifikujú ako etnickú skupinu a pri rozhovoroch o jazyku svoj liturgický jazyk nazývajú aramejčinou, nie mandejčinou. ${ }^{223}$ Je teda zrejmé, že stáročia vývoja v oddelených štátnych útvaroch viedli k vytvoreniu dvoch relatívne diferencovaných skupín Mandejcov, ktorí síce disponujú prakticky identickou vieroukou a ritualitou, ale samostatnou a jedinečnou etnickou a občianskou identitou.

V prípade iránskych Mandejcov je neodškriepitel'ný pozitívny vplyv aktívneho záujmu západných vedcov o mandejský jazyk, náboženstvo a kultúru na faktor sebauvedomenia, autoidentifikácie a formulácie vlastných identít. Terénny výskum v Ahváze potvrdil náš predpoklad, že Lady Drower a Rudolf Macúch a ich prínos pre štúdium mandeizmu a mandejčiny sú členmi miestnej komunity dodnes hlboko uctievané. Prof. Macúch je dodnes láskavo a humorne nazývaný "Mandejec bez brady", v kancelárii pri mandi nájdeme jeho zarámovanú fotografiu a množstvo výtlačkov rôznych jeho diel. Niet pochýb o tom, že jeho intenzívny záujem o mandejčinu a Mandejcov od prvého terénneho výskumu v pätdesiatych rokoch 20. storočia až do smrti v roku 1993 bol jedným z formatívnych faktorov dnešnej podoby etnickej identity Mandejcov z Ahvázu.

Taktiež mimoriadne dôležitým činitel'om pri zachovaní mandejčiny ako živého jazyka, resp. vytvorení modernej formy hovorovej

${ }^{222}$ Pre bližšie informácie o mandejčine pozri napr. Drower - Macúch 1963, Macúch 1965 alebo Macúch 1993.

${ }^{223}$ Rozhovory s informátormi v Dachau, Løgstør a Kodani (november 2015). 
mandejčiny je jazyková heterogenita Chúzestánu. Región je tradičnou historickou súčastou Iránu, jeho obyvatel'stvo je však značne zmiešané. Väčšinu tvoria etnickí Arabi hlásiaci sa k šíitskému islámu. Historicky druhou najväčšou skupinou sú Bachtijári a žijú, resp. v minulosti žili, tu aj relevantné skupiny Kaškajov, Lúrov, Arménov, židov a príslušníkov malých lokálnych etník resp. kmeňov. Vzhl'adom na prirodzenú jazykovú a konfesijnú rôznorodost' a z nej plynúcu nevyhnutnú etnickú toleranciu nebolo zachovanie a rozvoj živého mandejského jazyka vystavované vážnym výzvam.

Nie je celkom zrejmé kedy a z akých dôvodov dochádza k jazykovej asimilácii irackých Mandejcov. Oblast' irackej Mezopotámie je, najmä od druhej polovice 20. storočia, etnicky homogénnejšia než Chúzestán a západní vedci svoj terénny výskum od konca 19. storočia orientovali viac na Irán než Irak. Režim Saddáma Husajna sa, najmä kvôli kurdskej otázke, usiloval o arabizáciu etnických minorít. Bolo by teda možné predpokladat', že jazykovú asimiláciu vysvetl'ujú práve tieto faktory. Husajnov režim však Mandejcov toleroval ako štátom uznanú náboženskú menšinu a do určitej miery ich chránil, napríklad im v prípade potreby zabezpečoval policajnú ochranu pri nedel'nom krste. ${ }^{224}$ Navyše je z publikovaných výsledkov výskumu Lady Drower jasné, že k arabizácii irackých Mandejcov dochádza už niekedy pred prelomom 19. a 20. storočia: „Všetky inštrukcie, všetky legendy, mi boli odovzdané $v$ arabčine, príležitostne s nejakým mandejským slovom, kedže rațna (každodenná hovorová mandejčina) sa z používania vytráca a Mandejci v celej krajine hovoria arabsky. " 225

K jazykovej asimilácii irackých Mandejcov teda dochádza pravdepodobne v priebehu 19. storočia. Kedz̃e nemáme k dispozícii zdroje, ktoré by príčiny tohto fenoménu jednoznačne vysvetl'ovali, môžeme ich len predpokladat.

224 Pre bližšie informácie pozri napr. Gebelt 2007, 63.

225 Drower 1937, xxii. 


\section{Mandejci a výzvy súčasnosti}

V Iráne žili Mandejci tradične v regióne Chúzestán na juhu krajiny, najmä v mestách Ahváz, Chóramšahr, Šuštár a ich okolí. V posledných desatročiach však došlo k zretel'nému štiepeniu komunity, najmä následkom medzinárodnej a vnútroštátnej migrácie. Dôvodov bolo viacero. V prvom rade je nutné spomenút masovú emigráciu z krajiny po islámskej revolúcii v roku 1979. Hoci sú Mandejci spomínaní v Koráne ako ahl al-kitáb, ústava z roku 1979 ich neuznáva ako štátom uznanú náboženskú minoritu, na rozdiel od krestanov, židov a zoroastrijcov. V období po revolúcii dochádzalo k periodickým epizódam prenasledovania Mandejcov zo strany príslušníkov majoritnej populácie, ako aj štátnej moci. Hoci sa za ich zrovnoprávnenie okrem prominentných Mandejcov zasadzovali viacerí vysoko postavení príslušníci väčšinovej spoločnosti, ${ }^{226}$ k relevantnému posunu došlo až v rokoch 2013-2014, kedy došlo k formálnemu uznaniu Mandejcov ako samostatnej náboženskej skupiny. Komunity teda môžu vol'ne praktizovat' svoje náboženstvo, pokial' vieroučná a rituálna prax nie je v konfrontácii so zákonmi Islámskej republiky. Je napríklad zakázané realizovat náboženské rituály na verejnom priestranstve v mesiacoch ramadán a muharram.

Krátko po tom, ako vstúpila do platnosti ústava z roku 1979, postihla Mandejcov v Chúzestánu d'alšia tažká rana v podobe iracko-iránskej vojny rokov 1980-1988. Relevantná čast' bojov prebiehala práve v pohraničných pásmach Chúzestánu, Mandejci boli teda v prípade zotrvania v regióne pôvodu vystavení priamej hrozbe fyzickej likvidácie v rámci tažkých vojenských stretov.

Cielovými krajinami emigrácie v osemdesiatych rokoch 20. storočia boli predovšetkým Austrália, kde dodnes žije najpočetnejšia mandejská diaspóra, a USA.

Ďalším dôležitým faktorom vysvetlujúcim dnešnú rozdrobenost mandejskej komunity Iránu je urbánna migrácia $v$ rámci krajiny. Hlavnými motívmi tohto typu migrácie boli útek pred vojnou na juhu krajiny a ekonomická migrácia (lepšie možnosti štúdia a/alebo zárobku

226 Pre bližšie informácie pozri napr. Gebelt 2008, 46-47. 
resp. kariérneho uplatnenia vo väčších mestách). Takto v posledných troch až štyroch dekádach sledujeme vznik viac či menej ucelených mandejských komunít v rôznych väčších iránskych mestách, napríklad $\checkmark$ Teheráne či Šíráze.

Perzekúcia zo strany štátnych orgánov aj niektorých príslušníkov majoritnej populácie po revolúcii vplývala na komunity, ktoré v Iráne ostali, dvojako. V niektorých prípadoch, najmä pokial' sa individuálni veriaci alebo nukleárne rodiny presídlili $\mathrm{v}$ rámci Iránu do miest s menšou alebo žiadnou mandejskou komunitou, dochádza k oslabeniu náboženského prežívania a rituálnej praxe. ${ }^{227}$ Dôvody môžu byt čisto praktické - absencia kňaza a komunity, ktorá by stimulovala náboženskú prax - ako aj strach z prenasledovania alebo vol'ba „cesty menšieho odporu". 228

Na druhej strane však v rámci komunity v Ahváze, ktorej náboženské vedenie v osemdesiatych rokoch prebral šejch Sálem Čohejlí a stojí na jej čele dodnes (hoci väčšinu praktických úloh dnes už majú na starosti mladší kňazi), vidíme intenzívne snahy o posilňovanie náboženskej a etnickej identity. Napomáha im relatívna izolácia od majoritnej spoločnosti: Mandejci žijú vo vlastnej mestskej štvrti, hoci v tesnom susedstve ostatných mestských štvrtí; pracujú väčšinou bok po boku s príslušníkmi majoritnej populácie, v súkromnom živote však preferujú kontakt so spoluveriacimi. ${ }^{229}$

V Európe dochádza k vzniku relevantných mandejských komunít až po americkej invázii Iraku v roku 2003. Dovtedy väčšina irackých Mandejcov žila v relatívnom pokoji v regióne pôvodu, hoci aj tu v druhej polovici 20. storočia registrujeme značnú urbánnu migráciu, najmä za vzdelaním a lepšími ekonomickými podmienkami. Napätie a prenasledovanie náboženských menšín, ktoré nasledovalo po páde režimu Saddáma Husajna, však viedli drvivú väčšinu Mandejcov k opusteniu krajiny. ${ }^{230}$

227 Rozhovory s informátormi v Ahváze (október 2015).

228 Ibid.

229 Zúčastnené pozorovanie a rozhovory s informátormi v Ahváze (október 2015).

230 Neexistujú exaktné údaje o tom, kol'ko Mandejcov žilo v Iraku pred rokom 2003 ani kol'ko ich tam ostalo dodnes. 
Čast' z nich dostala azyl v rôznych krajinách západnej a severnej Európy a tak dnes môžeme sledovat proces adaptácie jednotlivých komunít.

Najväčší počet Mandejcov žije spomedzi európskych krajín vo Švédsku - ich počet sa odhaduje približne na 6500.231 V Nemecku ich momentálne žije približne $2200^{232}$ a v Dánsku $650 .{ }^{233}$ Menšie komunity nájdeme prakticky vo všetkých štátoch EÚ.

Ako bolo spomenuté vyššie, ritualita je neoddelitel'nou súčastou mandeizmu a mandejskej identity. Snaha o jej zachovanie zo strany kňazov i laikov je výrazne badatel'ná aj v diaspóre, je však významne obmedzovaná množstvom externých činitel'ov. Mandejské diaspóry sú roztrúsené vo viacerých väčších a menších mestách po celej krajine. Na prvý pohl'ad by bolo možné tvrdit', že vo vel'komestách ako Kodaň alebo Mníchov, by mohli vzniknút väčšie ucelené komunity s perspektívou pravidelného a častého stretávania za účelom realizácie rituálnej praxe. Bráni tomu však množstvo faktorov prostredia ako aj samotných komunít.

Po prvé, zúčastnené pozorovanie počas terénneho výskumu vedie k predpokladu, že Mandejci sú vel'mi dobre pracovne aj sociálne integrovaní v rámci väčšinovej spoločnosti. To znamená napríklad to, že do vel'kej miery prebrali štandardný časový harmonogram majoritnej populácie. Môžeme spomenút striktnú pracovnú dobu, ktorá, na rozdiel od štandardnej pracovnej doby na Blízkom východe zväčša neumožňuje mimopracovné aktivity počas na západe štandardného pracovného dňa. Pravidelné a časté komunitné stretávanie komplikuje aj účast Mandejcov na rôznych aktivitách organizovaných majoritnou spoločnostou, či už sú to mimoškolské aktivity alebo záujmové krúžky maloletých resp. dospelých (v prípade dospelých napríklad jazykové kurzy oficiálneho jazyka krajiny pobytu a rôzne kurzy zamerané na rozšírenie profesných zručností), ako aj rôzne spoločenské udalosti (stretnutia s kolegami z práce, rodičmi spolužiakov detí alebo so susedmi). Podobne ako členovia majoritnej populácie aj iných imigrantských skupín, aj

231 Rozhovory s informátormi s Dachau a Løgstør (november 2015).

232 REMID 2013.

233 Schou - Højland 2013. 
Mandejci majú často niekol'ko pracovných miest, bežne vyžadujúcich nižšiu kvalifikáciu akou reálne disponujú, a voliný čas, podobne ako väčšinové obyvatel'stvo Západnej Európy, trávia s nukleárnou rodinou a na každotýždenné kolektívne rituálne aktivity nemajú čas, energiu alebo chut. ${ }^{234} \mathrm{~V}$ neposlednom rade, život v sekularizovanej západnej Európe $\checkmark$ relatívne mnohých prípadoch vedie k oslabeniu záujmu o rituálne aktivity a náboženstvo ako také. Nie je zriedkavostou, že sa Mandejci v každodennom živote vôbec neriadia náboženskými predpismi, napríklad v oblasti stravovania alebo rituálnej čistoty, a o detailoch vlastného vieroučného systému majú prinajlepšom hmlistú predstavu. Títo jedinci väčšinou pri štruktúrovanom interview na otázky o viere či vierouke odpovedajú vyhýbavo ${ }^{235}$ alebo odpoved’ami typu „To sa musíte spýtat môjho brata, on vie o náboženstve viac, ja žijem ako Dán." ${ }^{236}$

Je rovnako dôležité poznamenat,, že pre Mandejcov žijúcich mimo vel'komiest s relatívne početnou komunitou by pravidelné cestovanie za účelom rituálnej realizácie znamenalo relevantnú časovú aj finančnú zátaž.

Po druhé, mandejská diaspóra v Európe zahŕňa relatívne málo kňazov spôsobilých realizovat väčšinu rituálov. V Nemecku sú podl'a informátorov momentálne „štyria alebo piati”237 a v Dánsku „jeden, ale chodia si pomáhat do Švédska a Austrálie aj odtial' sem. " ${ }^{238}$ To znamená jednak zvýšený tlak na samotných kňazov snažiacich sa efektívne slúžit geograficky roztrúseným komunitám, jednak nutnost' za účelom kolektívneho náboženského vyžitia prekonávat' často aj niekol'ko stoviek kilometrov.

Fyzicky je teda nemožné vo všetkých komunitách realizovat všetky rituály s frekvenciou, aká bývala bežná vo vlasti Mandejcov (napríklad mașbutu každú nedelu).

\footnotetext{
${ }^{234}$ Informácie pozbierané s rozhovorov s informátormi v Dachau, Løgstør a Kodani (november 2015).

235 Ibid.

236 Informátor Ch. Z. Kodaň (november 2015).

237 Informátor Ch. Š. Dachau (november 2015).

238 Informátor A. S. Løgstør (november 2015).
} 
Tretím a najdôležitejším faktorom sú poveternostné podmienky. Väčšina mandejských rituálov sa realizuje $v$ exteriéri a vyžaduje si ponorenie do tečúcej vody. Toto z pochopitel'ných dôvodov v krajinách západnej a severnej Európy nie je realizovatel'né počas celého roka, pokial' komunita nemá k dispozícii zdroj kontinuálne tečúcej vyhrievanej vody (napríklad vyhrievaný bazén s priebežne pritekajúcou a odtekajúcou vodou). ${ }^{239}$ Aktívny kolektívny rituálny život Mandejcov vo väčšine Európy je teda limitovaný na obdobie neskorej jari až skorej jesene, čo je značné obmedzenie oproti oblasti pôvodu, kde teplota ovzdušia a vody len zriedka obmedzuje vykonávanie rituálov vo vol'nej prírode, vrátane krstu ponorením väčšiny tela do rieky.

Na základe horeuvedených informácií je zrejmé, že samotná existencia mandejského náboženstva a komunít je vystavená vážnym hrozbám. Nepočetné mandejské komunity, ktoré ostali v Iraku, čelia reálnemu riziku vyhladenia, spoločenstvá v Iráne sú rozdrobené a v európskej diaspóre bráni pravidelnému združovaniu za účelom realizácie rituálnej praxe geografická roztrieštenost' komunít a vysoký stupeň integrácie. Považujeme teda za mimoriadne dôležité spoznat tieto komunity a upozornit odbornú aj laickú verejnost' na ich jedinečnú vieroučnú a rituálnu prax, ako aj na riziká, ktorým sú vystavené.

${ }^{239}$ Podla informátorov majú Mandejci takýto bazén k dispozícii vo Švédsku, v čase písania príspevku autorka toto tvrdenie ešte nevedela overit'. 


\section{Bibliografia}

Arabestani, Mehrdad. 2010. The Mandaean Identity Challenge. From Religious Symbolism to Secular Policies. Adelaide.

Arabestani, Mehrdad. 2012. „Ritual Purity and the Mandaeans' Identity." Iran and the Caucasus 16: 153-168.

Buckley Jacobsen, Jorunn. 2002. The Mandaeans. Ancient Texts and Modern People. Oxford: Oxford University Press.

Drower, Ethel Stefana. 1937. The Mandaeans of Iraq and Iran. Their Cults, Customs, Magic, Legends and Folklore. Oxford: Oxford University Press.

Drower, Ethel Stefana. 1950. Diwan Abatur or Progress through the Purgatories. Città del Vaticano: Biblioteca Apostolica Vaticana.

Drower, Ethel Stefana. 1953. The Haran Gawaita and the Baptism of Hibil-Ziwa: the Mandaic text reproduced, together with translation, notes and commentary. Città del Vaticano: Biblioteca Apostolica Vaticana.

Drower, Ethel Stefana a Rudolf Macúch. 1963. A Mandaic Dictionary. Oxford: Clarendon Press.

Escaping ISIS 20/20: Iraqi Christian Refugees Escape ISIS. 2015 ABC. [Dokumentárny film] https://www.youtube.com/watch?v=hjiafK61NPE (stiahnuté 27. 2. 2016).

Gebelt, Jiří. 2008. „Vývoj a proměny mandejské komunity.” Religio. Revue pro religionistiku 16: 33-55.

Gebelt, Jiří. 2009. „Masbuta. Mandejský křest.” Theologická revue 80: 44-65.

Gebelt, Jiří. 2010. „K mandejským rituálům.” Pantheon 7: 139-154.

Gebelt, Jiří. 2012. „Bádání o mandejcích. Problémy, tendence a perspektivy." Theologická revue 88: 315-339.

Jørgenssen, Steen A., Jens Beck Nielsen. 2013. „Mandæerne dropper slagtning uden bedøvelse." Berlingske 13. 8. 2015: http://www.b.dk/ nationalt/mandaeerne-dropper-slagtning-uden-bedoevelse (stiahnuté 20. 5. 2016). 
Korán, prel. Ivan Hrbek. 1972. Praha: Odeon.

Lidzbarski, Mark. 1925. Ginza der Schatz oder Das Grosse Buch der Mandäer. Göttingen.

Macúch, Rudolf. 1965. Handbook of Classical and Modern Mandaic. Berlin: Walter de Gruyter.

Macúch, Rudolf. 1993. Neumandäische Texte im Dialekt von Ahwāz. Wiesbaden: Harrassowitz.

REMID 2013: Religionswissenschaftlicher Medien- und Informationsdienst e. V. (2013) „Religionen \& Weltanschauungsgemeinschaften in Deutschland: Mitgliederzahlen": http://remid.de/info_zahlen/ verschiedene/ (stiahnuté 29. 1. 2016).

Schou, Kim a Marie-Louise Højland. 2013. „Hvem er mandæerne?” religion.dk (internetový zdroj): https://www.religion.dk/viden/hvem-er-mand\%C3\%A6erne (stiahnuté 20. 5. 2016).

Šomodiová, Katarína. 2016. „Az iraki keresztény menekültek befogadása Szlovákiában." BHKK Múhely: Biztonságpolitikai folyóirat I: 13-21. 


\section{Michal Habaj}

\section{Skýthové v Hérodotově mentálním světě: několik příkladů konstrukce Dějin}

\section{Úvod}

Řecký historik Hérodotos posunul v druhé polovině pátého století před n. I. zkoumání dějin k nové metě. Sesbíral ohromující množství zpráv kolujicích o dějinách v ústní tradici celého východního Středomoří a podal ho svým posluchačům v duchu svého vnitřního obrazu světa. Dějiny se nesnažil jen vyprávět. Jeho dílo mělo vysvětlit a zároveň posluchači/čtenári didakticky znázornit principy fungování společnosti, jakož i celého božského pořádku. ${ }^{240}$ Obklopený iónským racionalismem, sofistikou, zájmem o lékařství, geografii, politiku a etnografii, ${ }^{241}$ přitom hluboko zakořeněný $v$ tradiční vir̃e $v$ bohy a řecké pojímání božského pořádku, zkoncipoval své zprávy, poprípadě je poupravil, do podoby odpovídající vlastním ideovým představám, hodnotám - jinými slovy, svému mentálnímu světu.

Řecký historik tak tvơ̌il své dílo v duchu vlastního mentálního nastavení navázaného na dobový myšlenkový diskurs. Podle toho, co odpovídalo jeho racionalitě, si vybíral z různých verzí, ${ }^{242}$ poprípadě získané verze hodnotil nebo prímo odmítal. ${ }^{243}$ Vnitřní nastavení určovalo nejen výběr verzí, ale i jejich uspořádání, poprípadě přímo Hérodotovy vlastní

240 Nejlepší úvod k Hérodotovi poskytuje Asheri - Lloyd - Corcella 2007.

241 Dva aktuální pohledy na vliv dobového vědeckého a politického myšlení na Hérodotovu tvorbu podávají Thomas 2000 a Munson 2001.

${ }^{242}$ Např́klad: Hdt. 1. 95, 1. 216, 5. 46, 7. 214, 8. 64 atd.

${ }^{243}$ Např́klad: Hdt. 1. 7, 1. 75, 2. 16, 2. 28, 3. 9, 9. 84 atd. 
vklady. ${ }^{244}$ Výzkum Hérodotova vnitřního světa v souvislosti s jeho Dějinami umožňuje proniknout hlouběji k původním zprávám historika, pochopit jejich výběr, podání, uspořádání, rozpoznat nánosy autora, a tak přehodnotit informační potenciál podaných verzí. Naznačený předpoklad platí i v prípadě skýthského logu.

Zájem o Skýthy, jakož i Hérodotovy Dějiny, se u badatelů táhne už staletí, ale tyto dva směry poznání nikdy k sobě nenašly hlubší cestu. Skýthologie se opírala a opírá hlavně o archeologii a v ruské a ukrajinské historiografii hlubší studie obsahu Hérodotova díla chybí. ${ }^{45}$ Řecký historik, jako nejdůležitější literární pramen k reálím a dějinám Skýthů, bývá využiván na doplnění archeologických poznatků či na jejich včlenění do kontextu poznání. Zájem o Hérodota v tomto směru bádání tak nepřekračuje konfrontování archeologie $s$ jeho textem. ${ }^{246}$ V západní historiografii se věnuje Hérodotovi podstatné místo. K analýze a kritice textu dějin vyšlo nepřeberné množství monografií a studií. Často se sice dotýkají i skýthského logu, ${ }^{247}$ ale práce monograficky na něj zaměřená chybí.

Následujíci r rádky nemají ambici približit celý skýthský logos a podrobně ho vysvětlit. Do príspěvku jsem vybral jen některá ukázková místa, která umožňují pochopit uplatnění Hérodotových vnitřních postojů, představ a idejí prì tvorbě Dějin. Soustředím se jen na výpravu Skýthů do Levanty, povstání skýthských otroků a Dareiovu výpravu do Skýthie, avšak v rámci ní jen na několik podrobností.

\section{Levantská výprava (Hdt. 1. 105)}

V první knize svých Dějin nás Hérodotos informuje, že Skýthové podnikli v rámci svých vojenských tažení i výpravu proti Egyptu.

244 Např́klad: Hdt. 2. 109, 3. 45, 3. 146, 5. 10, 7. 173 atd.

${ }^{245} \mathrm{~K}$ dějinám ruského a sovětského zájmu o Hérodotův skýthský logos viz hlavně Neichardt 1982.

${ }^{246}$ Medveděv 2004, 139 kritizuje chybějící zájem ruských klasických filologů o vnitřní a vnější kritiku Hérodotova díla. Hlubší pohled prolínající zájem o Skýthy a antické prameny nepřinesly ani poslední práce, viz např. práce Kozulin 2015.

247 Hartog 1988; Lateiner 1989; Thomas 2000; West 2002; Corcella v Asheri - Lloyd - Corcella 2007. 
V Palestině odvrátil nájezdníky od vpádu k Nilu faraon (Psamtik I., 663-609 před n. I.). Většina Skýthů se sice vrátila, ale část Skýthů vyloupila v Askalóně chrám Afrodíty Uranie (možná Astarty), za což na ně bohyně seslala trest - ženskou nemoc. ${ }^{248}$

Hérodotos na tomto př́běhu zkoumá základní principy fungování božského pořádku. Př́klad výborně zapadá do jeho představ a světonázoru. Bohové v přesvědčení starověkých Řeků nestrpí znesvěcení svých chrámů. Viníky čeká krutý trest. Hérodotos vyslovuje ve svém díle přesvědčení o fungování kauzality „znesvěcení - trest“ několikrát. Ilustrativně na prípadě Artabazova obléhání Potidaje. Peršan obléhal město tři měsíce potom, co po bitvě u Salamíny od Peršanů odpadlo. Hérodotos vysvětluje neúspěch obléhání pomocí výše naznačené př́činy.

Když už Artabazos obléhal město tři měsíce, nastal na dlouhý čas veliký mořský odliv. Když viděli barbaři mělčinu, postupovali do Pallény. Měli za sebou již dvě pětiny cesty a tři jim ještě zbývaly, aby se dostali do Pallény, a tu nastalo veliké vzdutí moře jako dosud nikdy, jak tamni obyvatelé ríkají, ač se to stává často. Kdo neuměli plavat, zahynuli; ty, kdo uměli, pobili Potidajští, kteř́ připluli na lodích. Potidajští říkají, že přícinou záplavy a zničení Peršanů bylo, že ti z Peršanů, kdo zahynuli v moři, zneuctili chrám Poseidónův a jeho sochu na předměstí. Myslím, že to vykládají správně. (Hdt. 8. 129, překl. J. Šonka)

Trest za znesvěcení patřil do Hérodotovy představy o fungování světa a své čtenáře na ně upozorňuje vždy, když dostane př́ležitost. Lýdský král Alyattes tak onemocněl, nebot' vypálil chrám Athény (Hdt. 1. 19), Kroisův neúspěch proti Peršanům Hérodotos vysvětloval kromě jiného dobytím Efezu, zasvěceného Artemidě (Hdt. 1. 26), obyvatelé Kýmé měli být potrestáni za bezbožnost (Hdt. 1. 159), problémy perského krále na výpravě do Núbie začaly podle Hérodota inned po vyslání perského oddílu do sívské svatyně (Hdt. 3. 25), spartský král

${ }_{248}$ Podle druhé kapitoly pseudo-hippokratovského díla 0 vzduchu, vodách a místech se jednalo o formu impotence způsobenou př́lišným ježděním. 
Kleomenés zemřel podle řeckých zpráv pro znesvěcující čin (Hdt. 6. 75), Datis neuspěl u Marathónu kvůli uloupené soše Apollóna (Hdt. 6. 108). Tresty bohů patřily ke starověkému světu všeobecně. Hněvem bohů se vysvětlovaly mnohé neúspěchy či katastrofy předovýchodní civilizace, a když se obrátíme opět na Řecko, tak už v Illiadě nacházíme tvrzení, že člověka bojujícího proti bohům nečeká dlouhý život (Hom. II. 5. 407), jakož i varování před urážením bohů (Hom. II. 6. 128-141).

Vycházíme-li z těchto úvah, je lehké pochopit, proč si Hérodotos zmíněnou zprávu vybral a proč jí důvěřoval. Uchoval ji ve svém díle, nebot' dotvářela jeho výzkum dějinného pořádku, jeho představu o fungování světa a opět jednou jeho současníkům poskytovala didaktické exemplum. Hérodotos ji zahrnul do svého díla ani ne tak pro její historický význam, ale spíše pro význam morální a didaktický, zůstává přitom pro tuto událost jediným literárním pramenem.

\section{Povstání otroků (Hdt. 4. 1-4)}

Jádro Hérodotova vyprávění o Skýthech zůstalo uložené ve čtvrté knize Dějin. Vyprávění začíná návratem Skýthů ze západní Asie do vlasti. Po dobu dlouhé nepřítomnosti skýthských mužů se jejich manželky spojily s otroky a měly s nimi děti. Generace potomků otroků se postavila Skýthům vracejícím se z Médie na odpor. Skýthové se je jen marně pokoušeli porazit v několika následujících bitvách. Podle Hérodota po neúspěších prohlásil jeden ze Skýthů následující slova:

"Co to děláme, Skythové? Bojujeme se svými otroky, oni nás pobíjejí a nás ubývá, a když zase pobíjíme my je, budeme jich mít v budoucnu méně. Myslím, že bychom měli odložit kopí a luky, vzít každý do ruky koňský bič a tak se k nim přibližit, dokud viděli, že jsme ozbrojeni, mysleli, že jsou nám rovni a že pocházejí ze stejných předků jako my. Spatři-li, že máme místo zbraní biče, uvědomí si, že jsou našimi otroky, a když to pochopí, nevytrvají v odporu." (Hdt. 4. 3, překl. J. Šonka).

Skýthové se řídili radou, odložili kopí a luky, nahradili je biči. Otrokům připomenuli jejich postavení a vylekali je natolik, že se poddali. Příb̌h 
mohl mít historické jádro související se zprávami o konfliktech mezi Skýthy a podmaněným obyvatelstvem, ale jeho výstavba odpovídá akutním dobovým otázkám souvisejícím s postojem k otrokům, zároveň se dotýká obvyklého řeckého literárního motivu návratů.

Motiv bojů proti synům otroků, kteří vzešli ze vztahu svobodných žen s otroky po dobu nepřítomnosti jejich mužůu, se v řecké literatuře opakuje. Známe ho od Antiocha ze Syrákúz (FGH 555 F 13) a od Polybia (12. 5-10). Kromě toho Hérodotos připomíná podobnou situaci v Argu, kdy se v městě bez mužů zmocnili vlády otroci, ale neudrželi si ji, nebot’ se s nimi nespojily svobodné ženy, a když dospěla nová generace svobodných mužůu, byli otroci poraženi (6. 83). V otázce návratů přitom Hérodotos vycházel z dávné řecké tradice reflektující problémy spojené s dlouhou neprítomností a následným návratem např́klad i v Homérově Odyssei. Právě zde zabíjí Agamemnona milenec jeho manželky nad vlastním žlabem (4. 535), Odyssea čeká po strastiplném návratu do Ithaky boj s nápadníky jeho ženy a pylský mudrc Nestor radí v jedné pasáži Télemachovi o nepřítomnosti ve vlasti a problémech spojených s návratem těmito slovy:

Ty se i netoulej dlouho, můj milený, z domova vzdálen, opustiv všecko své jmění a zanechav ve vlastním domě muže tak nadmíru zpupné - sic všecko ti mezitím stráví, tvoje si rozdělí statky - a cesta tvá bude pak marná!

(Hom. Od. 3. 313-316, překl. 0. Vaňorný)

Přesně v tomto duchu se nese zpráva o návratu Skýthů a Hérodotovi tak zapadá do jeho vidění událostí. Řecký historik neměl důvod zprávě nedůvěřovat, odpovídala tomu, co sám o návratech hrdinů a celkově vojsk z výprav věděl a slyšel. Historik z Halikarnássu na historickém př́kladě problém návratu analyzuje a rozebírá. Studuje jeho jednotlivé prvky. Jedním z nich je chování skýthských manželek po dobu nepřítomnosti jejich mužů. Otroci se totiž zmocnili ve Skýthii moci poté, co se spojili se svobodnými ženami. Francouzský badatel Tourraix (La femme et pouvoir chez Herodote, 1976) dokázal na více jak 50 príkladech, že 
žena u Hérodota symbolizuje přechod moci a potomstvo ji udržuje. ${ }^{249}$ Na ilustraci postačí dva príklady: Peisistratos prišsel v Athénách o vládu podruhé, protože odmítl děti, které měl s Megaklovou dcerou (1. 61); Astyages nevědomky odevzdal médskou moc Peršanům ve chvíli, kdy svou dceru vdal za Peršana. Formulace zprávy o Skýthech tak zjevně souzní s Hérodotovými mentálními obzory. Platí to i o závěru príběhu, který reflektuje citlivou otázku otroctví. Skýthové nedokázali porazit otroky v tradičních bitkách a uspěli až když otrokům připomněli jejich pưvod s bičem v ruce. Toto pojetí je Hérodotovi vlastní. Chování jeho postav do velké míry určuje jejich původ a ne jejich aktuální sociální postavení. Výstižný príklad poskytuje Hérodotova biografie Kýra II. Kýros sice vyrůstal $v$ rodině pasty̌ře, jeho chování však vypovídalo 0 jeho vznešeném pưvodu (1. 116). Hérodotos tak celkem prirozeně príijal zprávu o synech otroků, kteří si při pohledu na bič vzpomněli na svůj původ, jako důvěryhodnou, pokud dokonce sám nesestavil tento príběh z více autonomních zpráv. Jeho pojetí přitom reflektuje dobový prístup k otázce otroctví. Bič a bití patřilo do sféry trestů otrokủ, stačí príipomenout, že o něco více než století po Hérodotovi zachytil řeckou ideologii k otrokům Myrón z Prieny (FGH 106 F 2) slovy, že spartští heilóti jsou pravidelně biti, „aby nezapomněli na to, že jsou otroky”.

\section{Perská výprava (Hdt. 4. 83-85, 87-93, 96-98, 102, 118-142, 7. 18, 20)}

Perská výprava představuje ústřední osu skýthského logu. Hérodotovi poskytla podstatný prostor pro vlastní úvahy. Vyplynulo to ze skutečnosti, že Řekové věděli o výpravě jen velmi málo. lónové se výpravy zúčastnili po Istros a potud Hérodotos zůstává ve výkladu poměrně konkrétní, ale o událostech dále na severu zůstala v řecké tradici pouze nejasná směs zpráv. Nedostatek informací poskytl Hérodotovi prostor, aby ho zaplnil dvěma způsoby. (1) Využil analogii a o neznámých věcech hovořil na základě toho, co dobře znal. ${ }^{250}$ (2) Vnesl do výkladu vlastní

249 Blok 2002, 232.

250 Při popisu poměrů v Egyptě doslovně uvádí, že analogie patří mezi jeho metodické postupy: "Když usuzuji podle známých věcí o neznámých, docházím k názoru..." (Hdt. 2. 33). 
vojenské, filozofické a politické úvahy, díky kterým výpravu rekonstruoval a které zpětně ilustrovaly jeho didaktické cíle. Opěrnou a referenční výpravou byla pro Hérodota prí analogii Xerxova výprava z roku 480 i s Mardoniovou dohrou v roce 479 před n. I. ${ }^{251}$

\begin{tabular}{|l|l|}
\hline Dareiova výprava cca. 513 & $\begin{array}{l}\text { Xerxova výprava } 480 \text { (včetně } \\
\text { dohry r. 479) }\end{array}$ \\
\hline $\begin{array}{l}\text { Výpravu omlouval vpádem Skýthů do } \\
\text { Médie, který se odehrál několik generací } \\
\text { zpět; }\end{array}$ & $\begin{array}{l}\text { Trest za řeckou účast v lónském } \\
\text { povstání }\end{array}$ \\
\hline Výprava začíná přechodem Istru & $\begin{array}{l}\text { Výprava začíná přechodem } \\
\text { Hellespontu }\end{array}$ \\
\hline $\begin{array}{l}\text { Nejednotní obyvatelé Skýthie pred } \\
\text { Dareiem ustupují }\end{array}$ & $\begin{array}{l}\text { Nejednotní Řekové preded Xerxem } \\
\text { ustupují až k Peloponésu }\end{array}$ \\
\hline $\begin{array}{l}\text { Dareios nedokáže přinutit Skýthy } \\
\text { k perskému způsobu boje a rozhodující } \\
\text { bitva se má odehrát v čase a na místě, } \\
\text { o kterém rozhodli Skýthové }\end{array}$ & $\begin{array}{l}\text { Xerxes se nechá nalákat na } \\
\text { rozhodující bitvu v prostoru } \\
\text { vyhovujícím Řekům }\end{array}$ \\
\hline Dareios neuspěl a ze Skýthie doslova utíká & Xerxes po bitvě u Salamíny utekl \\
\hline
\end{tabular}

Podobností mezi výpravami bychom našli víc, ale v základě postačí i naznačený rámec. Na něm Hérodotos postavil základy Dareiovy výpravy. Vystavěný rámec následně doplnil úvahami, které zřejmě kolovaly v iónském světě a využívaly perskou výpravu jako exemplum. Hérodotos je akceptuje, nebot patří do jeho ideového nastavení a mezi aktuální dobové otázky. Je těžko určit, do jaké míry sám tyto zprávy dotvárí a do jaké míry je zaznamenává v původní podobě, avšak zdůvodňování a hledání souvislostí mezi príčinami a následky patří nezpochybnitelně do jeho vlastní intelektuální výbavy.

251 Podle Lateinera $(1989,156)$ Hérodotos vykreslil Dareiovu výpravu tak, aby byl jeho popis událostí v roce 480 pochopitelnější. S touto intencí nesouhlasím, zůstává nepodložená, a možnost, že Hérodotos využil při Dareiově výpravě, o které neměl dostatek informací, zprávy z jiné a o mnoho známější perské výpravy, tj. z Xerxovy, se jeví mnohem realističtější. 
Hérodotos se zaobíral, tak jak bylo jeho zvykem, i při Dareiově výpravě do Skýthie jejími př́ičinami, a jak také bývalo jeho zvykem, viděl hlavní prríčinu tažení a následného neúspěchu v Dareiově hubris, tedy pýše (Hdt. 3. 134). Ve snaze proslavit se, Peršan napadl lid, který Persii ničím neublízil. Podle Hérodota konal nespravedlivě, protože chtít si přivlastnit cizí krajiny bez zjevné prríčiny označil Hérodotos vícekrát ve své práci za nespravedlivé. Snad nejlépe Hérodotos artikuluje tuto svou normu myšlení v odpovědi etiopského krále Kambýsovým poslům, které perský král vyslal jako předvoj pozdější výpravy do Núbie:

Perský král vás neposlal s dary, protože si klade za velkou čest stát se mým pohostinným př́telem, ani vy nemluvíte pravdu, nebot' jste přišli zhlédnout mou řiši, ani není Kambýses mužem spravedlivým. Kdyby byl spravedlivý, nebyl by zatoužil po jiné zemi nežli po své a nebyl by přiváděl do otroctví lidi, kteři se proti němu ničím neprovinili. (Hdt. 3. 21, překl. J. Šonka)

Hérodotos věří, že nespravedlnost a bezbožnost budou potrestané. Celá následující skýthská výprava se nese v tom duchu. Dareios překročil Istros, který představoval v jeho myšlení přirozenou hranici určenou bohy. Obyvatelé Skýthie se nespojili proti přicházející hrozbě a většina kmenů předpokládala, že pokud zůstanou neutrální, válka se jim vyhne. Hérodotos se rozhodl v tuto chvíli upozornit na skutečnost, že válce se vyhnout nedá. Skýthové totiž ustupují před Peršany přes území svých sousedů, čímž je zapojují do konfliktu. Hérodotos uvažuje nad možností, kterou představuje snaha vyhnout se válce, na vícero místech svých dějin. Neutralitu považoval za zdánlivou a nedosažitelnou. Doslovně to specifikuje v čase řecko-perských válek, když hovoří, že řecká města, která se nepostavila přímo vojensky proti Peršanům, se postavila v podstatě na Xerxovu stranu (Hdt. 8. 73). V řeckém světě se jednalo o citlivou otázku. Rozštěpenost řeckých obcí nahrávala Persii a snaha po jednotě ideologicky legitimizovala athénskou námořní říši, do jejíhož světa Hérodotos patřil. Poukázáním na nejednotnost obyvatelů Skýthie se tak řecký historik zapojil do dobového politického diskursu. 
Navzdory rozštěpenosti obyvatelů Skýthie Dareios nevyzrál na skýthský způsob boje. Přijal nepřátelskou taktiku a nechal se s velkým vojskem vodit po rozsáhlé krajině. Hérodotos přitom vícekrát upozorňoval na to, že Skýthy žijící kočovným způsobem života téměř není možné přinutit k rozhodující bitvě. Řecký historik při svých úvahách přišel na jediný způsob, jak Skýthy přimět k boji, a vnesl ho do zprávy skýthského krále Dareiovi. Posel oznámil Peršanovi, že Peršané budou muset najít skýthské hroby a rozkopat je, aby Skýthy zastavili. Hérodotos se tu zaobírá myšlenkami na vztah mezi rodovou společností a pochováváním, podobné problémy patří do myšlenkového světa Illiady či Sofoklovy Antigony.

Vojensko-taktické úvahy Hérodota tím nekončí. Nejúčinnější taktiku viděl ve vnucení svého typu boje nepríteli. Tím způsobem vojsko mǔže využít své přednosti a zároveň tak otevře slabá místa nepřítele. Řek ilustruje své úvahy o vítězné taktice v duchaplné radě Bianta z Priény Kroisovi. Lýdský král uvažoval nad výstavbou lod'stva a napadením řeckých ostrovů. Mudrc k němu promlouvá následovně:

"Ostrované skupují, králi, tisíce koní, protože mají v úmyslu vypravit se válečně do Sard a proti tobě." Kroisos myslel, že mluví pravdu, a odpověděl:

"Kéž by jen bohové vnukli ostrovanům myšlenku přijít proti synům lydským na koních!"

"Vidím, králi," opáčil návštěvník, „Že si z celého srdce přeješ porazit ostrovany na koních na pevnině a tvá naděje je oprávněná. A co myslǐš, že si přejí ostrované jiného, když se dozvěděli, že proti nim hodláš stavět lodi, než porazit Lýdy na moři, aby se ti pomstili za Řeky sídlící na pevnině, které jsi zotročil?"

(Hdt. 1. 27, překl. J. Šonka)

Tuto taktiku Hérodotos skloňuje při všech perských neúspěšných výpravách. Skýthská tažení jsou její ukázkovou studií: skýthský král využije silné stránky svého vojska a nadiktuje způsob boje svému nepř́teli. Dareios naskočil ve Skýthii na nepřátelský typ boje, opustil své výhody a musel být už z vojensko-taktického hlediska podle Hérodota potrestaný. 
V průběhu dalšího vyprávění prinnesli Skýthové do perského tábora ptáka, myš, žábu a pět šípů (Hdt. 4. 131). Dary měly symbolický význam. Vícero autorů jako Westová, 252 Merkelbach ${ }^{253}$ nebo Lateiner ${ }^{254}$ považovali poselství za možné a viděli v něm projev komunikace aliterárních kmenů žijících ve stepních oblastech, zdá se však, že zakomponování poselství do vývoje událostí může být jen Hérodotovou konstrukcí. Posluchač nebo čtenář Hérodotova príběhu už dávno v čase odevzdání poselství ví, že Dareios ve Skýthii neuspěje a uvědomuje si, že se Dareios mýlí, když poselství pokládá za znak skýthské kapitulace. Lateiner si všiml, že Hérodotos tímto způsobem vtáhne posluchače do príiběhu, ${ }^{255}$ a dodejme, že zároveň graduje napětí před rozuzlením. V symbolech, se kterými poselství zachází, však můžeme vidět ještě víc. Představují hádanku a čtenár ji poměrně lehko rozluští. Žáby, myši i ptáci patřili do světa řeckých príiběhů, nakonec už Homérovi bylo prípisováno parodické dílko 0 válce žab s myšmi a zoomorfní obrazy patřily do jazyka Íliady a Odyssey, jakož i světa bajek. Jen připomeňme, když se nahněvaný Achilles obrací na Agamemnona (Hom. II. 1. 225) se slovy, že má psí oči a zaječí srdce, bezpochyby si inned všichni Řekové domysleli, že označuje mykénského krále slabochem. Tento neverbální způsob vyjadřování patriil do Hérodotovy autorské výbavy založené na homérovské tradici.

Tento a předcházející príklady dokládají způsob, jakým se na Dějinách podepsal Hérodotův mentální svět. Žil v jistých představách, které specifikovaly zpưsob jeho uvažování a promítaly se do jeho tvorby. Už na uvedených príkladech se odrazil celý komplex zažitých Hérodotových a hlavně dobových struktur. Skýthský logos v nich neodpovídá pouze na snahu o popsání minulosti, ale i na řeckou obavu z návratů z dlouhých výprav; na ideologické problémy v otázce zacházení s otroky; zaznívá v něm silná a tradiční víra v bohy určující chod života; reší otázky bezpečnosti a s ní související problém řecké roztřištěnosti, či nakonec príipomeňme, že rozebírá i politické a vojenské otázky.

\footnotetext{
252 West 1988, 207-211.

253 Merkelbach 1975, 203-207.

254 Lateiner 1987, 83-107.

255 Lateiner 1989, 26-30.
} 


\section{Literatura}

Asheri, David, Alan Lloyd a Aldo Corcella. 2007. A Commentary on Herodotus. Books I-IV. Oxford: Oxford University Press.

Blok, Jan. 2002. „Woman in Herodotus' Histoire.” In Brill's Companion to Herodotus, vyd. Egbert Bakker, Irene De Jong a Hans Wees. Leiden: Brill.

FGH = Brill's New Jacoby I-V, vyd. Ian Worthington. Leiden: Brill, 1998-1999.

Hartog, François. 1988. The Mirrror of Herodotus. Cambridge: Cambridge University Press.

Hdt. = Hérodotos. 2003. Dějiny, přel. Jaroslav Šonka. Praha: Odeon.

Hom. II. = Homéros. 2007. Ílias, prél. Otmar Vaňorný. Praha: Rezek.

Jacoby, Felix. 1913. „Herodot.” In Realencyclopädie der classischen Altertumeswissenschaft, Supplement. II, 205-520.

Kozulin, Vjačeslav Nilajevič. 2015. Obraz Skythov v antičnoi literarnoi tradicii. Barnaul.

Lateiner, Donald. 1987. „Non-Verbal Communication in Herodotus.” Arethusa 20: 83-119.

Lateiner, Donald. 1989. The Historical Method of Herodotus. Toronto: University of Toronto Press.

Medvedev, Alexander. 2004. Antičnaja tradicia po archeologii i etnografii lesostepnoi Skythii. Voronež.

Merkelbach, Reinhold. 1975. „Zwei Bilder aus der Sprache der Reiternomaden." Zeitschrift für Papyrologie und Epigraphik 19: 203-207.

Munson, Rosaria. 2001. Telling Wonders: Etnographic and Political Discourse in the Work of Herodotus. Ann Arbor: University of Michigan Press.

Neichardt, Alexander. 1982. Skythskij raskaz Gerodota v otečestvennoi istoriografii. Leningrad.

Thomas, Rosalind. 2000. Herodotus in Context. Cambridge: Cambridge University Press. 
West, Stephanie. 1988. „The Scythian Ultimatum.” Journal of Hellenic Studies 108: 207-211.

West, Stephanie. 2002. "Scythians." In Brill's Companion to Herodotus, vyd. Egbert Bakker, Irene De Jong a Hans Wees, 437-457. Leiden: Brill. 


\section{Simona Levá Jandová}

\section{Motiv kmene Kuravů v tamilském žánru kuravaňdži 256}

Jedním z nejzajímavějších jevů pozdního středověku v tamilské literatuře byl vznik celé řady žánrů, které, i když jejich autory zůstávali tradičně vzdělaní básníci, byly určeny pro široké publikum a v nichž se poprvé objevily zcela nové typy literárních postav z řad nižších kast a minorit. Kromě nových témat díky nim do světa vysoké kultury proniklo také rozvolnění prozódie a použití hovorové formy jazyka v dialozích. Mezi tyto žánry se řadí i kuravaňdži. Popularitu tohoto žánru, který prosperoval nejvíce od 17. do 19. století, dosvědčuje dobrá stovka textů, jež se dochovala ve formě rukopisů a které postupně shromáždily instituce, které se věnuji studiu starých tamilských děl (např. Dr. U. V. Swaminatha Iyer Library, Thanjavur Saraswati Mahal Library, Govt. Oriental Mss. Library a jiné). Název žánru v tamilštině znamená doslova žena z kmene Kuravů. 257

Žánr je definován svým obsahem. Všechna kuravaňdži vypráví jeden př́iběh, jehož jádro tvoří popis toho, jak kmenová žena předpoví budoucnost zamilované hrdince, půvab jednotlivých textů pak spočíá

\footnotetext{
256 Tento výstup vznikl v rámci projektu „Kulturní techniky: materialita, medialita a imaginace” podprojektu „Výzkum orální tradice vážící se k inscenaci tanečních představení kuravaňdži“ řešeného na Filozofické fakultě Univerzity Karlovy v Praze z prostředků Specifického vysokoškolského výzkumu na rok 2016. V textu budu používat u tamilských výrazů používat český přepis, v seznamu literatury pak vědeckou transkripci.

257 Tamil Lexicon 1962, 1046. U hesla kuravaňdži (kuravañci) uvádí dva možné významy, 1. žena z kmene Kurava, jasnovidkyně, 2. druh dramatické básně.
} 
ve způsobu vyprávění, v kráse poezie, originalitě autorovy představivosti a jeho dovednosti při práci s jazykem. Každé kuravaňdži opěvuje nějakého urozeného hrdinu, jímž může být bůh z místního chrámu, místní panovník a nebo jiná významná osoba. Tento hrdina v příběhu vystupuje pouze neprímo. Ličí se jeho krása, vyzdvihuje jeho výjimečný charakter a jedinečné zásluhy. Po úvodních verších, které uctí jednotlivé bohy, se setkáme s hrdinkou, urozenou dívkou, která přihlížela procesí hrdiny ulicemi a zamilovala se do něj. Milostné trápení pak líčí tradiční verše známé z dvorské poezie, v nichž si hrdinka stěžuje na svůj stav bohu lásku, měsíci, jižnímu vánku a své přítelkyni. Rozhodnou se přivést Kuratti, ženu z kmene Kuravů, která zná minulost, př́tomnost i budoucnost, aby jí předpověděla, zda její touha dojde naplnění. Kuratti je skutečnou hlavní postavou kuravaňdži. Její příchod na scénu je impozantní a ličí ho velmi rozpracovaná pasáž, která nechá vyniknout její odvážné a nezávislé povaze a poskytne prostor pro informace o jejím kmeni a jeho zvycích, horách, jež obývá. Kuratti se rozhovoří o všech místech, která již navštívila, o způsobech věštění, které ovládá, a štědrých darech, které si díky této své dovednosti zasloužila. Zapůsobí na hrdinku jako schopná a moudrá žena a získá si její důvěru, takže ji hrdinka požádá, aby jí také předpověděla, co ji čeká. Kuratti provede obřad, při kterém vzývá bohy, aby ji obdařili schopností vidět do budoucnosti, a pak hrdince věští z ruky, z různých prírodních znamení a jiných náznaků. Pak vstoupí v transu do kontaktu s bohy a předpoví, že hrdina hrdinku pojme za ženu. Po úspěšné předpovědi se objeví Kuravan, mužský příslušník kmene Kuravů a manžel naší Kuratti. Kuravan a jeho pomocník jsou nejprve zachyceni při výkonu tradičního kmenového povolání, lovu ptáků. Posléze se Kuravanovi zasteskne po manželce a vydá se ji hledat. Hned poté následuje jejich shledání, které přinese nejprve drobnou roztržku mezi manžely zapřičiněnou př́lišnou nezávislostí Kuratti a manželovou žárlivostí, po nǐž následuje usmî̃ení a uctění bohů, jímž kuravaňdži končí.

Texty kuravaňdži nebyly určeny ke čtení, nýbrž sloužily jako libreto pro taneční představení, která se konala v minulosti v jihoindických chrámech. Představení kuravaňdži probíhala po celou noc, hrdinka 
zasažená krásou hrdiny neseného v procesí začala tančit po soumraku, usmîrení kmenového manželského páru se odehrávalo před rozedněním. Tančilo se v př́slušných kostýmech v ryze ženském obsazení za hudebního doprovodu. V představení, které se konalo vždy při jasně stanovených chrámových festivalech, účinkovaly dévadásí, chrámové tanečnice a kurtizány, ženy formálně zasvěcené chrámu. Kuravaňdži byla vysoce ceněnou a oblíbenou částí jejich slavnostního repertoáru.

S úpadkem statusu dévadásí v průběhu 19. století představení kuravaňdži až na pár výjimek v chrámech úplně zanikla. Informace o hudební a taneční části představení se povětšinou nedochovala, protože se předávala pouze v komunitě hudebníků, tanečních mistrů a dévadásí pouze orálně, tudíž se naprostá většina kuravaňdži do 20. století uchovala již jen v textové podobě. Všechna kuravaňdži však měla původně podobu nebo alespoň úmysl tanečních představení, jak nám naznačují kusé zprávy v rukopisech o jejich prvním uvedení nebo nahodile poznamenané názvy rágy a tály $\mathrm{k}$ některým veršům, z nichž sice není možné přesně obnovit pưvodní znění hudby, nicméně je ž̌ejmé, že byla zhudebněna. Když došlo kolem poloviny 20. století k záchraně tance dévadásí a jeho obnově do podoby standardizovaného klasického tance bharatanátjam, byla oživena celá řada představení kuravaňdži, některá v rámci možností navazují na přetrvávající orální tradici vážící se k jejich inscenaci, jindy jde o ryzí rekonstrukce představení z textové podoby s nově složenou hudbou a novou choreografií, vše pochopitelně upravené pro současné městské publikum. To mimo jiné znamená zkrácení představení na délku jedné až jedné a půl hodiny, zdưraznění hlavní dějové linie a využití divadelních kulis a osvětlení, které kompenzuji ztrátu kontextu, kterou způsobil přenos původně rituálního představení z chrámu do městského sekulárního prostředí. V takto upravené moderní podobě si kuravaňdži znovu získala oblibu diváků a drží si ji dodnes.

Pro řadu badatelů představují kuravaňdži v první řadě vyprávění o kmeni Kuravů. „Studium kuravaňdži není ničím jiným, než studium komunity Kuravů, která byla dávnou komunitou na tamilské půdě," píše ve svém úvodu k vydání Muttejjéndirar kuravaňdži jeho editor 
S. Soundarapandian ${ }^{258}$ a podobný význam tématu přiznává i Buck ${ }^{259}$ ve studii doplňující jeho anglický překlad Tirukkutrála kuravaňdži.

Motiv kmene Kuravů se neomezuje pouze na žánr kuravaňdži. Oblíbené postavy Kuravů vystupují v celé řadě príběhů z mytologie a v mnoha tradičních divadelních žánrech v jižní Indii a Kuravové jsou v nich líčeni jako božský kmen, jehož príslušníci ovládají celou škálu nejrůznějších kouzel. Nejrozšiřenější legenda, která pracuje s motivem kmene Kuravů, vypráví o tom, jak mezi nimi vyrostla krásná dívka jménem Valli, která se pak stala druhou manželkou významného drávidského boha Muruhana. Především v jihoindických státech Tamilnádu a Kérala se v lidových divadlech často setkáváme s motivem př́slušníkủ tohoto kmene, kteř j jsou ovšem ve skutečnosti některými z bohů hinduistického panteonu, kteří sestoupili na zem v tomto přestrojení.

V zárodečné podobě se motiv Kuravů objevil i v tamilské literatuře již dávno. Panniruppáttijal, príručka pro básníky popisující tvorbu různých básnických žánrů z 10. století, zmiňuje žánr s názvem kurattippáttu, píseň Kuratti, ${ }^{260}$ ve kterém žena mluví o minulosti, prítomnosti a budoucnosti v deseti slokách. Nedochoval se nám žádný príklad od tohoto žánru, ale téma později vstoupilo do jiných žánrủ, až se osamostatnilo a nabylo rozpracované podoby a velké popularity v kuravaňdži.

Celá řada badatelů, kteří zkoumali a editovali texty kuravaňdži, pak ve svých studiích zdůrazňuje, že žánr poskytuje celou řadu etnografických informací o kmeni Kuravů. Editor Kumbéšar kuravaňdži S. Kalijánasundarejjarar ${ }^{261}$ ve svém eseji již z r. 1944 také poukazuje na to, že text zachycuje řadu zvyků kasty Kuravů a souhlasí s ním také S. Soundarapandian, ${ }^{262}$ který věnuje ve svém eseji Kuravům celou pasáž nadepsanou Etnologický pohled, i editor Sarapéndira Bhúpála kuravaňdži, Aranga Sínivásan, když vytvořil seznam zvyků kmene Kuravů v kuravaňdži ${ }^{263}$ Někdy bývají zdůrazněné i zvláštnosti, jimiž

258 Soundarapandian 1997, 11.

259 Buck 2005, 18.

260 Muilwijck 1996, 194.

261 Kalijánasundarejjar 2002, viii-ix.

262 Soundarapandian 1997, 6.

263 Sínivásan 2004, 17-18. 
se mluvní projev příslušníků kmene Kuravů odlišuje od většinového obyvatelstva. ${ }^{264} \mathrm{~V}$ některých kuravaňdži je jejich jazyk zachycen jako směsice tamilštiny a telugštiny, jinde dochází pouze ke změnám ve výslovnosti nebo začlenění zvláštních slov, která patří jen do slovníku Kuravů. Protože badatelé zdůrazňovali etnologickou hodnotu kuravaňdži, rozhodla jsem se prozkoumat na několika textech kuravaňdži, jaké informace lze z kuravaňdži vyčíst a zda by bylo možné využít je pro určení toho, kdo byl předobrazem božského kmene Kuravů.

\section{Popisy Kuravů}

Celý kmen Kuravů v textech kuravaňdži zastupuje především samotná Kuravaňdži, žena z kmene obdařená jasnovideckými schopnostmi, nejčastěji označovaná v textech jako Kuratti (výraz Kuratti je tvar feminina od označení kmene a je synonymní ke Kuravaňdži), v o něco menší mî̃e Kuravan (muž z kmene Kuravů) a do jisté míry i jeho pomocník. Kuravan i Kuratti, jak jsou manželé označováni, nejsou osobní jména. Z pohledu urozených hrdinů kuravaňdži i autorů těchto textů je dostačující určit je pouze jako kmenové obyvatelstvo. Jejich vlastní jména se objevují, až když hovoří kmenoví manželé mezi sebou. Nejčastěji se jmenují Singan a Singi (v překladu Lev a Lvice), jméno pomocníka bývá různé.

Nejvíce informací o kmeni je soustředěno v dlouhém dialogu mezi urozenou hrdinkou a Kuratti. Další informace získáváme z písní, které popisují, jak kmenoví manželé vypadají a co dělají. V případě Kuravana jde především o popis tradičního lovu ptáků, schopnost Kuratti předpovídat budoucnost je pak zachycena do mnoha detailů.

Příchod každé hlavní postavy oznamuje píseň, která obsahuje popis této postavy, prípadně vyzdvihuje její vlastnosti a připomíná její skutky. Příchod Kuratti, která je vlastně hlavní postavou celého příběhu navzdory tomu, že sanskrtské poetiky za hrdinku označují zamilovanou dívku, protože s neurozenými postavami nepočítají, je dlouho očekávaný a oznamuje ho hned několik písní, z nichž se dnes pro potřeby představení používá jen malá část. Její nástup je vskutku impozantní

264 Např. v úvodu k Ardhanáríšar kuravaňdži (ed. Pašupati, Méhalá, Sájiráman 2002, $\mathrm{xV}-\mathrm{xvi}$. 
a jak vyplynulo z mého terénního výzkumu v r. 2016 v Čennej, právě její specifický způsob tance, jenž stojí na pomezí lidového a klasického tance, je hlavním důvodem, proč i současné choreografy láká uvést alespoň jednou za svou kariéru představení nějakého kuravaňdži.

Verše věnované Kuratti v textech ji popisují jako krásnou ženu, často za použití podobných metafor, jako když popisují krásu mladé hrdinky, ale zdůrazňují také její vědomosti a schopnosti. V Tirukkutrála kuravaňdži ${ }^{265}$ několik veršů ukazuje, jak je její príchod očekávaný (přichází jako elixír na horečku lásky, jako mladá kukačka do háje v období jara) a co se od ní očekává (bude číst znamení jako odbornice, má vědoucí oči). Nikdy nesmí chybět popis jejího kostýmu, který ji jasně označuje jako příslušnici kmene, a její nejdůležitější rekvizity: kouzelná hůlka a košík. Kuratti v Kumáralinga kuravaňdži266 má ve vlasech arabský a divoký jasmín, na hlavě šperk sutti, na čele pattam, na uších koppu a zlatý šperk, černidlo kolem očí, diamantový šperk v nose, náhrdelník z bílých perel, zlatý náhrdelník, náhrdelník z mušlí, náhrdelník ze skořápek arekových ořechů, santál na prsou, další náhrdelníky, zárivý pásek na dalším pásku, náramek vyrobený z mušlí, nákotniček, kouzelnou hůlku a kouzelnou krabičku, perly na prsou.

Príchod Kuravana je méně významný a popisuje ho mín veršu. V Kumáralinga kuravaňdži má Kuravan náhrdelníky z mušlí, drobné šperky, pižmovou tečku na čele, zdobenou horní část oděvu, krátké červené kalhoty, velký náhrdelník s príivěskem, špičaté hole, luk a šíp, ozdobu hlavy. V Tirukkutrála kuravaňdži Kuravana zdobí chocholka z volavky ve vlasech, náhrdelník z čapích zobáků na hrudi, zvir̃ecí kůže kolem pasu, má toulec plný šípů, sukovitou hủl, zbraně, smyčky z provazů. Dále ho charakterizuje parádivý krok a pouhý pohled na jeho zuřivost zastraší

265 Tirukkutrála kuravaňdži se tradičně považuje za nejdokonalejší příklad celého žánru. Jeho autorem je Tiruhúdarádžappa Kavirájar a svoji premiéru mělo r. 1718 v Kutrálam, což je poutní místo s chrámem na jihu Tamilnádu. Opěvuje lokální kutrálamské formy boha Šivy a jeho choti.

${ }^{266}$ Autor Kumáralinga kuravaňdži je neznámý. Text je věnovaný místnímu panovníkovi Kumáralingarovi, který vládl pravděpodobně v 18. století jedné malé oblasti v Tamilnádu. 
tygra. V Rišivindam kuravaňdži ${ }^{267}$ má Kuravan peří čápů a páva, mušle kaurí kolem krku, je vybaven lukem a šípy, flétnou, sítí na ptáky a klecí na úlovek, napodobuje zvuky ptáků, aby je nalákal. Kuravanův přítel má podobné ozdoby z peří a nese vybavení na lov ptáků.

\section{Kuratti vypráví o svém kmeni}

Postava Kuratti má dostatek prostoru, aby promluvila nejen o sobě, ale i o svém kmeni, jeho zvycích a místě, které obývá. Za domov komunity Kuravů jsou v každém kuravaňdži označeny hory, obvykle konkrétně pojmenovaná místní hora nebo kopec. Sama Kuratti často použivá př́domek Horská Kuratti nebo Kuratti z hor. Fantasticky pohádkové popisy horské krajiny jsou klenoty každého kuravaňdži a předhání se v nadsázce a přehánění. Podporují tak božský charakter připisovaný kmeni Kuravů v mytologii a jejich výjimečný vztah s bohy.

Jeden z nejkrásnějších popisủ horské krajiny se nachází v Tirukkutrála kuravaňdži. Jsou to verše, které se školní děti často učí recitovat zpaměti, a oblíbená část představení, která se často tančí i samostatně jako součást sólových tanečních vystoupení. Krása veršů vynikne především v originále, nebot' kromě velmi melodické tamilštiny obsahuje celou řadu básnických ozdob a nejrưznějších slovních hříček, kdy např. výraz pro velké opice současně může znamenat nebeští básníci apod.

Opičáci dávají opicím ovoce a objímají je.

Bozi na nebesích je prosí o ovoce,

které opice nechaly upadnout.

Lesní lidé pozvedají oči,

aby pozvali bohy z nebes.

Asketi, kteři ví jak, létají za světla po obloze

právě tady v těchto horách, tady pěstují svá těla,

která nikdy nepodléhají rozkladu.

267 Autorem Rišivindam kuravaňdži je básník Rádžappa Ubáttijájar a je věnováno bohu Šivovi Ardhanáríšvarovi z chrámu v Rišivindam v Tamilnádu. První představení se podle dochované poznámky v závěrečném verši konalo roku 1867. 
Medové vodopády vyvěrají ze země a protékají oblohou, takže kopyta koní (boha) slunce s červenými paprsky a kola jeho vozu uklouznou po hoře Tirikúdam pána Kutrálamu, toho, jenž zdobí své rozcuchané vlasy ohnutým mladým srpkem měsíce.

Ta hora je naše.

Horská krajina, kterou obývají Kuravové, je vždy plná kouzel, je jí věnována celá řada písní. Autor Rišivindam kuravaňdži v jedné z nich vyjmenovává všechny druhy léčivých rostlin, které tam rostou na hoře Vindam.

Máme tam bylinky, které promění měd've zlato!

Jiná naše bylina odstraní chut' k jídlu jednou pro vždy!

Nejjedovatější černí plazi tam jsou

ve svých skrýších -

Také je tam bylina, která nás zachrání před

smrtelným hadím kousnutím!

Je tam bylina, která umí rozlomit

i pevnou hůl na kusy!

Je tam bylina, která ochromí

pohyby končetin!

Je tam bylina, po které se muži pokorně podřídí

a jdou za tebou na krok!

Čtyři druhy bylin tam jsou schopné

udělat z lidí nesmrtelné!

Je tam bylina, která nám ukáže

skryté poklady země!

Je tam bylina, která léčí neplodnost

u žen a po níz otěhotní!

Je tam bylina, s kterou můžeme létat 
vysoko po nebi!

Je tam bylina, díky niž můžeme čelit i hněvu

nelítostného vládce!

Kmen Kuravů, který tyto divutvorné končiny obývá, je obdařený podobnými nadpřirozenými schopnostmi. Některé popisy se soustředí na to, jaký význam mají Kuravové v mytologii. Př́kladem takového popisu kmene může být Rišivindam kuravaňdži. V něm jsou Kuravové především ti, kteří dali dívku ze svého kmene za manželku samotnému bohu Muruhanovi, a spolu s ní věnem i páva jako jízdní zvîre a horské království.

Vznešenému Muruganovi, synu Pána z Rišivindam, jsme darovali dívku z našeho klanu za manželku.

Se vší ochotou, ó paní!

Pán s tváří s kly je švagrem té dívky

a Vznešený Šankara je náš blízký príbuzný díky té svatbě, ó paní!

Protože si vznešený Murugan vzal naši dívku Valli, nabídli jsme mu páva jako jízdni zvir̃e a království v horách jako věno, ó paní! Nespočet králů přišlo žádat o ruce dívku z našeho klanu a odešlo zklamaných

když byla jejich přání zamítnuta, ó paní!

Nabídli jsme horu pokrytou sněhem Pánu s rozcuchanými prameny vlasů, aby na ní žil

a nabídli horu Méru, aby sloužila jako dvorní sín̆ pro nebeštany, ó paní!

Nenašla jsem žádné kuravaňdži, v němž by se popisy soustředily pouze na skutečné zvyky, ale někde jsou magické schopnosti Kuravů promíchány s realističtějšími informacemi. Takový popis kmene poskytuje například Kumáralinga kuravaňdži. 
Náš kmen Kuravů je božský kmen Kuravů, kamkoli jdeme na této zemi, tam žijeme, tak je naším pravidlem. (...)

Nepotíráme se santálem ani cibetem , nemluvíme kromě našich manželů s jinými muži,

naše mysl nezná strachu ze života na této velké zemi.

Když se někdo proviní proti našim zvyklostem

nebo když vypouští z úst hloupá slova, nevyčitáme mu to.

Každý den chodíme do hor a tam žijeme, zdobíme se rưznými zpưsoby šňưrami mušlí nebo perel. Umíme zkroutit pisek do provazu, zázračným způsobem.

Zamilované ženy, pokud nás o to požádají,

vyléčíme z veškerého zmatku.

Nejíme vrány, orly, sovy ani divoké krávy.

Nevedeme své mysli k tomu, abychom někoho obrali o majetek, poté co bychom mu napovídali Iži.

Žijeme odděleně a nescházíme se pospolu po mnoho dní. Naše tělo nezeslábne jako u jiných žen z malého zklamání. (...) Nelžeme a neříkáme urážky.

Nedáváme si do vlasů dobré květiny véngej ani bílé květiny. (...) Známe mnoho druhů kouzel, paní, poslouchej.

Neznámý autor tohoto textu se snaží božský charakter kmene doplnit detaily, které mohl získat pozorováním skutečných kmenových obyvatel. Jeho Kuravové jsou tedy na jedné straně božský kmen Kuravů, jehož príslušníci ovládají řadu různých druhů kouzel, jako ukroutit provazy z písku a zbavit zamilované ženy nejistoty, ale doplňuje je o různé zvyklosti, co se týče způsobu života. V jeho popise Kuravů najdeme zmínku o nomádském způsobu života - kamkoli jdeme, tam žijeme, žijeme odděleně a nescházíme se dohromady po mnoho dní. Přímá informace o nomádství není v písních kuravaňdži častá, ale vyplývá jasně z dalších písní Kuratti, např. těch, kde líčí, jaká místa navštívila (především posvátná místa spojená s poutnictvím), a komu všemu kde předpovídala úspěšně budoucnost. Další verše vypadají, že by mohly odkazovat k určitým pravidlům, jimiž se řídí nebo má rídit způsob života 
Kuravů - nemluvíme s jinými muži než manžely, nevyčitáme nikomu provinění a hloupá slova. Dále ukazuje, čím se kmenoví obyvatelé liší od většinového obyvatelstva - zdobíme se šñurami mušlí a perel (nebo korálků), nepotíráme se santálem ani cibetem, nedáváme si do vlasů bílé květiny.

Zajímavé na tomto popisu je, že se snaží vymezit vưči nejčastějším předsudkům, které obyvatelé vyšších vrstev vǔči kmenovým, prípadně nomádským komunitám mívají. Tamilové považují kmenové obyvatelstvo za špinavé a bez respektu k porádku. Mají řadu prísloví, která tyto predsudky ${ }^{268}$ dobře odráží, např. „krást jako Kurava”, „hádky mezi Kuravy nemají konce“, „poté, co zloděj Kurava sní drůbež, ji vyrazí s majitelem hledat".

Konkrétně Kuratti zdůrazňuje, že její kmen nelže a neusiluje o cizí majetek, nevyvolávají spory a také nekonzumuji nečistá zvî̃ata (vrány, orly, sovy, divoké krávy). Dále uvádí, že ženy z jejího kmene nemají ve zvyku mluvit kromě svých manželů s jinými muži. Tímto se snaží bránit proti rozšîrenému názoru vy̌ších kast, že ženy z řad kmenového obyvatelstva nebo dalitů jsou volných mravů. ${ }^{269}$ Studium kuravaňdži však navzdory tomu ukazuje, jak tyto predsudky byly mezi autory rozšřrené. Za pozornost v tomto ohledu stojí např. píseň o chuti jednotlivých druhů ptáků uvedená níže nebo závěrečný dialog mezi kmenovými manžely, které bez výjimky obsahují jak prvky hádky, tak výměnu poněkud obscénních narážek.

\section{Popis tradičních povolání Kuravů}

Celý kmen a jeho zvyklosti zastupují v kuravaňdži manželé Kuratti a Kuravan. Kuratti je vyobrazená jako schopná věštkyně, Kuravan především jako lovec ptáků. V kuravaňdži se piše o různých formách kouzel hned na několika místech - když se Kuratti vychloubá svými magickými schopnostmi, když mluví obecně o tom, co dokáže její kmen, a někdy i ve vztahu ke Kuravanovi. Je ž̌ejmé, že magickými schopnostmi

\footnotetext{
268 Jackson 1989, 12.

269 Pro srovnání Pillai-Vetschera 2007, 237.
} 
nevládne jen Kuratti, která v kuravaňdži vystupuje, ale všechny ženy z kmene, a do jisté míry jimi disponují i muži, nebot' v mnoha kuravaňdži Kuravan slibuje nejrůznější bylinky s magickými schopnostmi odměnou za pomoc s hledáním manželky, kterou začal postrádat. Popisy různých kouzel podporují představu, že kmen disponuje zvláštními schopnostmi nebo má výjimečný vztah s bohy. Lov ptáků se popisuje při př́chodu Kuravana, ale opět je povolání charakteristické pro všechny muže z kmene Kuravů, náš Kuravan se na něj vydává v doprovodu pomocníka.

\section{Kouzla a čtení budoucnosti}

Kuratti v Kumáralinga kuravaňdži umí provést malé i velké kouzelnické triky: královské kouzlo; kouzlo, které získává vládu nad ženami; kouzlo s ohněm; kouzlo s vodou; kouzlo, které druhé poplete; odstranit šedé vlasy a vrásky; stvořit ryzí zlato; znalost minulosti, prítomnosti a budoucnosti. ${ }^{270}$

Žánr se soustředí na podrobný popis jednoho z jejích kouzel a to jasnovidectví. Kuratti použije svou znalost minulosti, prítomnosti a budoucnosti, aby zamilované hrdince předpověděla, co ji čeká. Obřady, které čtení budoucnosti doprovázejí, jsou popsané v mnoha písních.

V Kumáralinga kuravaňdži Kuratti nejprve instruuje hrdinku, jak má provést prípravné obřady.

Potři zem santálem a z toho santálu udělej hezký vzor. Ozdob ten blízký květinový keř. Na banánovník přivaž skvělé kořeny marukkoluntu. Dones skvělý koláček módaham, spolu se třemi kousky ovoce a množstvím arekových listư na púdžu zázračnému Ganapatimu. Vem do ruky sezamové kuličky a dósy s horkým jídlem z prosa, a početné pori s bílou smaženou rýží, sem je polož a pomodli se. Dej sem džbán plný zlata. Odměř mírku perel a dej je sem dolů. Vezmi velký kus jasně zbarvené třpytivé látky a polož ji sem s radostí. Modli se s touhou, přaním, úctou a prosbou. Řeknu ti znamení tvé mysli, poslouchej, paní."

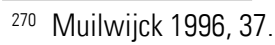


Dále hrdince říká, jak přesně má uctít bohy -nabídnout jim obětovaného berana, uctít bohy všech stran, obléci si na obřad sváteční sárí, poklonit se palmovému stromu, sklonit s k chodidlům krále Kumáralingara, uctít obětinami bohyni Márijammál, Angálammej, napravit své chyby atd., až je podle Kuratti vše připraveno k vlastní predpovědi budoucnosti. Poté vyzve hrdinku, aby se dotkla prstem jejího košíku a kouzelné hůlky. Následně ji vybídne, aby si zvolila měsíc, květinu a znamení zvěrokruhu. Z jejích slov Kuratti určí, do koho je hrdinka zamilovaná. Na otázku, kdy král príijde, Kuratti ze znamení soudí, že ještě toho dne. Těmito znameními jsou v Kumáralinga kuravaňdži její nateklá kulatá prsa, chvění levé ruky hrdinky, to, že nad branou zakrouží orel, ozve se zvuk kevuli, zahouká sova,další dobrá znamení prínese temný mrak a ondatra, hned nato Kuratti předpoví príchod krásné ženy se zprávou a věncem. Ta se skutečně v tu chvíli objeví a sdělí hrdince, že její vyvolený, král Kumáralingar, se rozhodl přijmout ji za manželku. ${ }^{271}$

Popis čtení budoucnosti a doprovodného rituálu se $\mathrm{v}$ jednotlivých kuravaňdži liší jen málo. V Tirukkutrála kuravaňdži Kuratti za přínivá znamení označí to, že promluvila mladá dívka s nateklými prsy, nějaká osoba kýchla, vrána proletěla vlevo od nich, ozval se zvuk ještěrky. Pak vyzve hrdinku ve verších, aby pripravila vše pro uctění bohů:

Vylešti podlahu, nakresli kólam.

Postav tam Vinájakara, at to je, jak má být, ammé!

Dones malou nádobu, obětuj ovoce

a rozbij kokosový ořech, ammé!

Připrav posvátnou trávu, vodu a lampičku.

Pak přines arekové orechy a betelové listy, ammé!

Priprav nějaké vadai, appam, aval a podobná jídla

s cukrem, pori a sezamovými kuličkami, ammé!

Odměř plnou mírku rýže a

sepni ruce k modlitbě k pánu, ammé!

271 Muilwijck 1996, 38-39. 
Nyní pochopíš podstatu věci.

Ucti svého rodinného boha, ammé!

Když Kuratti během obřadu vstoupí do přímého kontaktu s bohy, přečte z její ruky, že jejím manželem se stane pán osmi směrů a z ní bude vládkyně celého světa. Aby si Kuratti zajistila, že její předpověd' se splní, vzývá pak celou řadu bohů:

Ó, Vinájahare, který žije

$\checkmark$ blízkosti toho,

jehož levá polovina je bohyně

jejiž hlas je bambusová flétna,

toho, který vlastní zakrslý chlebovník!

Ó, Muruhane z Tiruččendúru

ó, Muruhane, zeti Višnua s červenýma očima!

Ó, Skando!

Ó bože z Ilaňdži, chraň mě!

Ó bohyně podobné ptáku majna

narozená však z jelena axise, paní z kmene Kuravů Valli,

prijjd'mi pomoci!

Ó otče! Ó králi Západních Ghátư!

Ó nebeštanky v nepopsatelných horách!

Ó bože Árijankávu!

Ó ty milostivý, který nás zasypáváš perlami! Ó, bojovníku,

který stojí pevně na mocném Kulattúru!

Ó překrásná Mahákálí!

Ó mladá ženo, která chrání Kutrálam!

Ó věčný Bhairavo!

Ó Karuppane s tvým velkým bubnem!

ó Muruhane, který běží napřed!

Ó králi Vannijare!

Ó Pandri Mádane, který útočí jako tygr!

Ó bohyně Jekkalá! Ó Durgo! Ó Pidári!

Naléhavě vás všechny žádám, 
abyste požehnali této předpovědi

a nechali ji vyniknout:

předstup přede mne nyní.

Pak se Kuratti obrátí na bohy s otázkami a následně nahlas vysloví, do koho se hrdinka tohoto kuravaňdži zamilovala a že jím je sám bůh Šiva, který sídlí v chrámu v Kutrálam. Je zřejmé, že k předpovědi budoucnosti dochází ve stavu transu, kdy skrze Kuratti mluví bozi. Kuratti vyjadřuje svou oddanost bohu Šivovi, zde pojmenovaného jako pán z Kutrálam, a pak ji posednou bohyně Džakka a Kurali. Jsou to bohyně spiš lokálního významu. Džakka je spojována s magickými silami, které mohou být jak dobré, tak zlé, a její chrám se nachází nedaleko Kutrálamu. Kurali je duch spojovaný nejčastěji s černou magií.

Láska k pánu Kutrálam

stvořiteli, který se zdobí kousajícími hady, mě posedla

a říká jasně, co přinesla. Bohyně Džakka

mi buší na rty a jazyk, a Kurali bije přes ústa a nutí mluvit, paní!

Poslyš nyní, jak ti řeknu, co tě čeká.

V Rišivindam kuravaňdži hrdinka připravuje podle instrukcí Kuratti podobný obřad. Má potřít podlahu kravským lejnem, z něj vymodelovat sošku Ganéši, před niž pak položí kokos, betel a betelové ořechy, čerstvé květiny a kadidlo a po předání odměny jí má ukázat dlaň ruky. Kuratti opět identifikuje celou řadu přiznivých znamení (cvrlikání gekona se ozve z jihu, sova zahouká, vrána zakráká, dostane tik do levého oka a ramena) a pak vzývá bohy, díky nimž je schopná nazřít budoucnost a prozradit ji hrdince.

Krátce po předpovědi dojde i ke štastnému uzavření celé části věnované hrdince a Kuratti proto dostane i svoji odměnu. 0 odměně za předpověd' budoucnosti se hovoří v několika písních. Nejvíce, když Kuratti chce zapůsobit svými zkušenostmi na hrdinku, v té samé písni, kde vyjmenovává nejrůznější místa, která navštívila, zmiňuje i různé významné osobnosti, kterým věštila, v některých kuravaňdži skutečné osoby, v jiných různé bohy, a vždy uvádí, jak byla za svou úspěšnou 
předpověd' štědře odměněna. Někdy hovoří i o tom, jak úspěšné jasnovidky jsou i různé její ženské přibuzné a jakých darů se dostalo jim. V Kumáralinga kuravaňdži Kuratti mluví o své sestřenici, švagrové, tchyni a babičce, které díky této činnosti získaly všechno možné od kbelíku na mléko a šatů po vzácné druhy šperků, když předpovídaly ženám z různých koutů jižní Indie a manželkám bohů. ${ }^{272}$

Kurattti v Tirukkutrála kuravaňdži předpovídala ženám nejen v jižní, ale i v severní Indii, na Srí Lance a v daleké Číně. Básník do této písně umně začlenil i historické informace o místním králi, který v roce 887, čili roku 1720 našeho letopočtu nechal zastřešit měděnou střechou jednu mandapu v kutrálamském chrámu.

Bylo to $v$ roce osm set osmdesát sedm

kdy náš vlastní Cinnanejňdžá Dévar založil

svoji slávu po celém dobrém městě Kutrálam.

Pokryl mědí překrásný malovaný sál

který byl předtím zastřešený

malými doškovými taškami pándijským králem

který podporoval tamilštinu, již chválil velký hadí guru.

Ale než tak učinil, já předpověděla jeho budoucnost

a tak mi dal tento kouzelný náhrdelník.

Podívej, ó nejkouzelnější z žen!

Skutečná odměna bývala zřejmě skromnější. V Rišivindam kuravaňdži Kuratti od hrdinky žádá rýži a šaty. V Tirukkutrála kuravaňdži trochu rýžové kaše, aby zasytila žaludek, a k tomu betel na žvýkání a trošku toho, co vozí z Číny, čili čaje.

Dones mi cokoli

i kdyby jen kaše, paní!

Kdy na to prijide, vypiju i vodu

abych si naplnila břicho, paní!

Dones mi náklad betelových ořechů a listů

na žvýkání, paní!

272 Muilwijck 1996, 40. 
A dej mi špetku toho, co

sem vozí z Číny, paní!

\section{Lov ptáků}

Kuravové se v kuravaňdži zabývají lovem vodního ptactva do pastí a sítí. Kuravan spolu s jedním pomocníkem prochází zavlažovanou zemědělskou krajinou a hledá ptáky. Jedná se o různé druhy vodních ptáků, jako jsou volavky a kachny. Některé použité názvy označují celé skupiny ptáků, jiné konkrétní druhy. Ptáci přiletí ve velkém množství a dosednou na pole nebo k vodní nádrži a začnou lovit ryby. Lovci rozmístí své sítě a pasti, Kuravana, který se rozpovídal o tom, jak mu chybí jeho žena, napomene jeho př́tel, aby byl zticha, aby ptáky nevyplašili, a pochytají je. Písně, které popisují různé druhy práce, pravděpodobně původně pocházejí z lidové tvorby a zpívaly se při výkonu těchto povolání.

Popis lovu ptáků z Tirukkutrála kuravaňdži:

Hej, Kuluvo,

když pritlačíme na naše osidla

z různých smyček,

budou to vrány, kdo se chytí,

ano, vrány se chytí.

Hej, Kuluvo,

když obrátíme naše

osidla s širokými smyčkami,

budou to čápi, kdo se chytí,

ani, čápi se chytí.

Hej, Kuluvo,

když utáhneme naše

povislá osidla

budou to bekasiny,

kdo se chytí,

ano, bekasiny se chytí. 
V některých kuravaňdži je pak ještě uvaří a sní, jak ukazuje např. píseň z Rišivindam kuravaňdži o chuti masa jednotlivých ptáků.

Ó, kamaráde! Poslechni si o chuti

masa různých ptáků!

Ty chutě zná dokonce i pán Vindam, který je slavný po celém světě!

Maso vrabců zlepšuje výdrž!

Maso ptáků sémpóttu umožní jasně vidět i v temnotě!

Sladká vioně masa ptákủ kádej zůstane dlouho na dlani i v ústech!

Kdo mǔže odolat pokušení sníst maso

ptáku kaudári?

Tolik touže ochutnat maso páva, někdo prý olizoval maltu!

Tu historku zná celý svět!

Naše srdce by nám vyčitala, kdybychom to popreli!

Nic se nevyrovná chuti masa kukačky

Když uvař́me maso čápa,

libá vůně prostoupí vše kolem!

\section{Kdo jsou Kuravové z kuravaňdži?}

Z uvedených kuravaňdži poměrně jasně vyplývá, že v nich mnoho konkrétních informací o kmenovém obyvatelstvu nenajdeme. Kuravové v kuravaňdži nejsou v první řadě obyčejný kmen, ale pro svůj blízḱ́ vztah s bohy jsou vyzdvihováni jako kmen božský s odkazy na řadu epizod z hinduistické mytologie. Autoři kuravaňdži vždy jistým způsobem oscilují mezi idealizovaným a realističtějším popisem, přičemž se liší v tom, kterému extrému se približují. Mytologický význam Kuravů a jejich neobyčejná schopnost nahlédnout do budoucnosti vede k tomu je vyzdvihnout na pomyslný piedestal, jejich nízké společenské postavení doprovázené řadou předsudků zase umožňuje zahrnout do př́iběhu komické scény a uzavř́t jej manželskou hádkou s erotickým podtextem. Realističtěji působící informace často nějakým způsobem reagují na 
představy, jaké mají príslušníci vyšších společenských vrstev o Kuravech a to bud" v tom smyslu, že je potvrzuji (např. píseň o chuti masa ptáků) nebo vyvracejí (např. popření konzumace ptáků v Kumáralinga kuravaňdži). Zahrneme-li takto do studie větší množství textů, pak spíše, než abychom se dopracovali k souboru různých zvyků, který by se rozšiřoval a vzájemně podporoval, zjištujeme, že víc než o zachycení nějakého konkrétního kmene, jak o něm piší někteří badatelé, autoři opakují a udržuji určitý literární a kulturní stereotyp.

Když badatelé ve studiích kuravaňdži uvádí, že v nich nacházi řadu etnografických informací o kmeni Kuravů, mívají často na mysli komunitu Narikuravů, nomádského obyvatelstva, s nímž se lze setkat v některých oblastech jižní Indie. Podobně i můj výzkum současných inscenací kuravaňdži prokázal, že pokud se choreografové rozhodnou obohatit konvenční zobrazení postav Kuravů, jejich tance, kostýmu, projevu o něco nového, pak se inspirují také u nich. Narikuravové patří antropologicky i jazykově k typu rozšrî́enému v severozápadní Indii, odkud žrejmě na jih přišli. ${ }^{273}$ Narikurava v překladu znamená lovec lišek nebo šakalů (přislušník kmene, který loví tato zvir̃ata). Označují se také jako Kuruvikkarové, lovci ptáků, prípadně Vagríválové, mluvčí jazyka vagríbolí. Tento jazyk je př́ibuzný západoindické gudžarátštině, ale existuje pouze v mluvené verzi. Jako nomádi se ovšem dovedou domluvit i běžnými jihoindickými jazyky, v Tamilnádu p̌̌edevším tamilsky. Žijí v nízinách na okraji společnosti a živí se lovem ptáků a jiných drobných zvir̃at do pastí a prodejem šperků z korálků nebo lastur a ženy někdy predpovídají budoucnost. ${ }^{274}$ Navzdory velké chudobě Narikuravové vždy vzbuzovali pozornost svou „exotickou krásou a pyšným, téměř drzým vystupováním". 275

Historie jejich přesunu do jižní Indie a jejich zvyků je téměř nezjistitelná. ${ }^{276}$ Britskými koloniálními etnografy byly nomádské komunity zařazeny mezi kriminální kasty. ${ }^{277}$ Bohužel většina tehdejších etnografů

273 Jackson 1989, 3-4.

274 Buck 2005, 77.

275 Jackson 1989, 2.

276 Jackson 1989, 13.

277 Např. E. Thurston, W. J. Hatch. 
neměla úplně jasno v rozčlenění jednotlivých kmenových skupin a často řadí pod stejné heslo Kuravy, Kurumby, Koravy, Koračy.

Tím se př́mo dostáváme k problematice výrazu Kurava v současné tamilštině. Jeho použití je totiž velmi vágní a kromě konkrétního kmenového společenství nap̌r. zmíněných Narikuravů označuje i kmenové obyvatelstvo obecně. Tento výraz se vyskytuje už v nejstarší tamilštině. Jeho etymologie podle Drávidského etymologického slovníkư ${ }^{278}$ jej spojuje s výrazem kundru, které znamená kopec nebo hora a v nejstarší tamilské literatuře se vztahuje k horskému obyvatelstvu. Hory byly obydlené převážně kmeny. Např. sangamový básník Nakkírar ve své dlouhé básni Tirumuruhátruppadej (Průvodce k bohu Muruhanovi) píše o dívkách z kmene Kuravů, které tančí na svazích hor a uctívají obětinami boha Muruhana, zatímco jejich šaman je v transu. ${ }^{279}$ I v kuravaňdži jsou za domovinu kmene označovány hory a Kuratti se často říká Horská Kuratti. To realitě Narikuravů neodpovídá, i když řada dalších zvyků na ně sedí. Není však těžké si představit, že jak se vyvíjely různé literární žánry, které pracovaly s tématem kmenového obyvatelstva, mohla za předobraz božského kmene sloužit celá řada různých skupin kmenových společenství, ve starší době žejmě kmeny obývající neprostupné lesy v jihoindických horách, později nomádští Narikuravové, s nimiž se většinová populace setkávala častěji.

Jednu věc však studium kuravaňdži ukazuje jasně a to, že v něm bohužel konkrétní historické etnografické detaily o konkrétní kmenové skupině nenajdeme, protože je používá pouze pro okořenění zavedeného mytologického a literárního stereotypu.

278 DEDR, heslo 1844.

279 Jackson 1989, 13. 


\section{Literatura}

Buck, David C. (přel.). 2005. A Kuravanji in Kutralam. A Tamil tale of love and fortunes told. Chennai: Institute of Asian Studies.

Burrow, Thomas a M. B. Emeneau. 1984. A Dravidian etymological dictionary. Oxford: Clarendon Press.

Cīñivācañ, Arañka. 2004. Carapēntira pūpāla kuravañci nāțakam. Chennai: Yāı Veliyițu.

Hatch, W. J. 1928. The Land Pirates of India: An account of the Kuravars, a remarkable tribe of hereditary criminals, their extraordinary skill as thieves, cattle-lifters and highwaymen and their manners and customs. London: Seeley, Service, and Co.

Jackson, William J. 1989. Rituals of a "Gypsy" Tribe: The Vagri or Narikuravar. A Brief Background Sketch. Religious Studies, Indiana Univ. - Purdue Univ. Indianapolis: Regional American Academy of Religion Conference, Bloomington, IN, 4/8/1989.

Jagannathan, K. V. (vyd.). 1982. Kumāralinkar kuravañci. Chennai: Sri Makāmakōpāttiyāya Ṭākțar U. Vē. Cāminātaiyar nūl nilaiya velịyițu.

Kaliyāṇacuntaraiyar, S. (vyd.). 2002. Kumpēcar kuravañci nāțakam. Chennai: Makāmakōpāttiyāya Ṭākțar U. Vē. Cāminātaiyar nūl nilaiya nilaiyam.

Muilwijk, Marina. 1996. The Divine Kura Tribe. Kuravañci and other Prabandhams. Groningen: Egbert Forsten.

Pacupati, Ma. Vē, Ňā. Mēkalā, Es. Cāyirāman (vyd.). 2002. Arttanārīcar kuravañci ennnum Tiruccerikōtțuk kuravañci. Chennai: Țākțar U. Vē. Cāminātaiyar nūl nilaiya velìyițu.

Pillai-Vetschera, Traude. 2007 (first ed. 1999). „Ambedkar's Daughters: A study of Mahar Women in Ahmednagar District of Maharasthra." In Dalits in Modern India. Visions and Values, vyd. S. M. Michael, 235 -259. New Delhi: Sage Publications Ltd.

Samuel, G. John a M. Maruthamuthu (vyd.). 2005. A kuravañci of Rișivintam. Chennai: Institute of Asian Studies. 
Soundarapandian, S. (vyd.). 1997. Muttaiyēntirar kuravañnci. Chennai: Goverment Oriental Manuscripts Library Publication.

Tamil Lexicon. 1965, reprinted 1982. Madras: University of Madras.

Thurston, Edgar. 1909. Castes and Tribes of Southern India. Madras: Government Press (heslo „Kurava”, sv. 4, 122-123). 


\section{Tomáš Retka}

\section{Jazyková politika současné Tádžické republiky v historicko-politických souvislostech ${ }^{280}$}

Jazyková př́slušnost představuje jeden z významných faktorů, důležitých pro utváření a udržování pocitu společné etnické identity. ${ }^{281}$ A právě otázka etnické identity je tématem, jehož prostřednictvím se autor textu snaží přistupovat a analyzovat otázku jazykové situace v dnešní Tádžické republice. Autor k danému tématu přistupuje především prizmatem své specializace, tedy sociální antropologie. Nicméně dílčím cílem příspěvku je zmínit i aspekty dané problematiky v rovině historické a politické.

Tento text vychází z poznatků, které autor postupně získával v průběhu svých výzkumných pobytů, které realizoval v letech 2006 až 2015. ${ }^{282}$

\section{Jazyková situace Tádžikistánu - základní vymezení}

Tádžická republika má v současné době vlastní kodifikovaný úřední jazyk, jehož název je odvozen od názvu samotného státního útvaru. ${ }^{283}$ Vedle tádžičtiny, která má jako jediná status úředního jazyka Tádžické

${ }_{280}$ Vznik této studie byl finančně podpořen FHS UK v rámci projektu PRVOUK (P20/2013/53).

281 Například Bromlej 1980; Smith 2003; Eriksen 2007 aj.

282 Autor realizoval v Tádžické republice pět antropologických terénních výzkumů zaměřených na problematiku etnických identit tádžických Pamírců (2006, 2012, 2013, 2014 a 2015). Další zkušenosti a poznatky autor získal v roce 2013 v průběhu výzkumného pobytu v Moskvě. Pokud bude v textu odkazováno na poznatky získané v průběhu terénního výzkumu, bude vždy odkazováno následujícím způsobem: Retka 2006-2015. 283 Horák 2008. 
republiky, je velice rozšr̃rená i ruština. ${ }^{284}$ Ruský jazyk podle legislativy Tádžické republiky v současné době plní funkci jazyka pro komunikaci mezi národy. Tento status ruštiny přímo upravuje druhý článek ústavy Tádžické republiky. ${ }^{285}$ Znalost ruského jazyka je v současné populaci Tádžikistánu stále rozšiřená286 a je poměrně bezproblémové se tímto jazykem domluvit i s příslušníky neruských skupin, kteří v dnešním Tádžikistánu žijí. ${ }^{287}$

Kromě tádžičtiny a ruštiny jsou v Tádžické republice zastoupeny i mnohé další jazyky. Významný lingvistický zdroj www.ethnologue.com, který se specializuje na jazyky světa, konstatuje, že v Tádžické republice je zastoupeno třináct různých jazyků. ${ }^{288}$ Podle tohoto zdroje se jedná o deset jazyků původních a tři jazyky nepůvodní. Za původní jazyky jsou považovány: tádžičtina, arabština, uzbečtina, kyrgyzština, parya, jaghnóbština a jazyky pamírské (iškašimština, jazgulámština, šugnánština a vachánština). Jako nepưvodní jazyky jsou uvedeny ruština, paštunština a perština. Tento pracovní výčet však Ize doplnit i o další jazyky, např́klad Nargis Rahmonová se zmiňuje i o početné komunitě Tatarů. ${ }^{289}$ Vladimír Baar navíc zmiňuje i Turkmeny, Kazachy a Ujgury. ${ }^{290}$ Hermann Kreutzmann dále upozorňuje, že kromě zmíněných skupin v minulosti (v době SSSR) žili na území dnešního Tádžikistánu i Němci a Ukrajinci ${ }^{291}$

Je tedy patrné, že různé zdroje mohou o dané situaci informovat nejednotně. Nejednotné mohou být i snahy o klasifikaci jednotlivých jazyků do větších zastřešujících skupin. Již bylo zmíněno, že lingvistický server www.ethnologue.com, rozlišuje jazyky "původní"

\footnotetext{
${ }^{284}$ Viz také: Ministerstvo zahraničí ČR. Dostupný z http://www.mzv.cz/jnp/cz/ encyklopedie_statu/asie/tadzikistan/index.html [cit.2015-09-05].

${ }^{285}$ Text ústavy Tádžické republiky: http://www.refworld.org/pdfid/3ae6b50910.pdf [cit.2016-04-15]. Originální verze v ruském jazyce byla publikovaná 30.11.1994 (in Leninabadskaya Pravda).

286 Horák 2008, 138.

287 Autor textu při svých terénních výzkumech také používá především jazyk ruský.

288 Ethnologue - Languages of the World: https://www.ethnologue.com/country/TJ/ languages [cit.2016-04-17].

289 Rahmonová 2011.

290 Baar 2002.

291 Kreutzmann 2015, 373.
} 
a „nepůvodní” (viz předchozí text). Problematiku autochtonních jazyků zmiňuje i Vladimír Baar, který ji ovšem spiše reflektuje v kontextu příslušníků státních národů ostatních středoasijských republik (viz další text). Nargis Rahmonová zmiňuje kromě čtyř významných jazykových konceptů292 i skupinu pátou, kterou lze označit za „další indoevropské jazyky", jejichž představitelé představují různorodé jazykové menšiny. Některým z těchto jazyků bude věnován prostor především v další části textu, nicméně je Ize nyní alespoň stručně zmínit. Jedná se o perštinu - fársí (cca 50000 mluvčích), parya (1195 mluvčích), jaghnóbštinu ${ }^{293}$ (cca 2000 mluvčích), paštunštinu a skupina jazyků, které jsou označovány jako jazyky pamírské (viz další text). ${ }^{294}$

Výše uvedené základní vymezení Ize stručně doplnit o otázku zastoupení autochtonních skupin, jejichž příslušníci tvoří majoritní obyvatelstvo sousedních států (či jiných administrativních útvarů). Tuto problematiku zpracovává Vladimír Baar, který konstatuje, že v devadesátých letech žilo v Tádžické republice přibližně 1000 Ujgurů, 15000 Kazachů, 70000 Kyrgyzů (především sever GBA0295 a okolí města Džergital) 1440000 Uzbeků, 25000 Turkmenů a 2000 Afghánců. Nejpočetnější etnické-jazykové menšiny v Tádžické republice tedy vytváří Uzbekové (téměř milion a půl obyvatel) a Kyrgyzové. ${ }^{296}$

Zajímavou skutečností, na kterou Baar poukazuje, je početné tádžické osídlení mimo vlastní stát. Jedná se 0 téměř 1200000 Tádžiků v Uzbekistánu a přibližně 4500000 v Afghánistánu. ${ }^{297}$ Podle tohoto

\footnotetext{
292 Tato autorka hovoří o čtyřech nejvýznamnějších etnických - jazykových skupinách žijících v Tádžikistánu: 1) majoritní tádžické obyvatelstvo, které žije především v nížinách, 2) etničtí Rusové žijící především ve velkých městech - Dušanbe, Chudžant, Kuljab atd., 3) uzbecké obyvatelstvo, které tvoří majoritu v severozápadních oblastech Tádžikistánu - především ve městě Chudžant a v jeho okolí, 4) Kyrgyzové žijící především ve východní části Gorno-Badachšánské autonomní republiky.

293 V českém akademickém prostředí se jaghnóbskému jazyku věnuje L'ubomír Novák, který sepsal a vydal první jaghnóbsko-český slovník (Novák 2010).

294 Veškerá data uvedená v tomto odstavci pocházejí ze zdroje GORDON, Raymond G., Jr. (ed.). . Dostupnýz zwww.ethnologue.com/show_country.asp?name=TJ, [cit.2009-06-10]. 295 GBAO - Gorno-Badakhshanskaya Avtonomnaya Oblast, viz další text.

296 Baar 2002.

297 Baar 2002.
} 
zdroje informací byla v devadesátých letech populace Tádžiků v Afghánistánu početněǰší, než populace Tádžiků ve vlastním Tádžikistánu. Tádžici v Afghánistánu tvoří druhou nejpočetnější etnickou skupinu po Paštunech. V roce 2006 v této středoasijské republice žilo príbližně 31 milionů obyvatel, z toho 42 \% tvořili Paštunové a $27 \%$ Tádžici (což by znamenalo více než osm milionů obyvatel). ${ }^{298}$ Nargis Rahmonová konstatuje, že mimo Tádžickou republiku žije celkem přibližně 10000000 Tádžikủ. ${ }^{299}$ Kromě Uzbekistánu tato autorka zmiňuje i vysoký počet Tádžiků žijících v Ruské federaci. ${ }^{300}$

Vysvětlení poměrně vysokého počtu Tádžiků v sousedním Uzbekistánu Ize hledat především v administrativních aktivitách sovětského vedení ve dvacátých letech dvacátého století. Jak upozorňuje napríklad František Bahenský, administrativní hranice nových sovětských socialistických republik či jejich nižších autonomních částí, mnohdy neodpovídaly hranicím etnickým. Tuto situaci František Bahenský vysvětluje snahou Moskvy zamezit vzniku etnicky homogenních administrativních jednotek. Etnicky heterogenní územní jednotky, ve kterých se předpokládal nižší potenciál společné koordinace, měly zaručit snazší kontrolu z centra. ${ }^{301}$ V důsledku této sovětské politiky „přišla“ Tádžická ASSR o Samarkand a Bucharu, tedy o dvě významná tradiční centra, ve kterých Tádžici $v$ dané době tvořili většinové obyvatelstvo, a které prì novém vytváření hranic v sovětské Střední Asii pripadly Uzbecké SSR. ${ }^{302}$

\section{Úřední jazyk tádžičtina}

Podle údajů z roku 1991 hovořilo v té době tádžickým jazykem 3340720 obyvatel Tádžikistánu. ${ }^{303}$ Vladimír Baar uvádí, že v roce 1997

\footnotetext{
298 Šlachta 2007.

299 Rahmonová 2011.

300 Na základě vlastních poznatků může autor konstatovat, že důvodem vysokého počtu Tádžiků v Moskvě a dalších ruských centrech je především fenomén pracovní migrace z bývalých sovětských středoasijských republik. Retka 2006-2015.

301 Bahenský 2010, 18-19.

302 Rahmonová 2011.

303 Kokaisl 2007, 218-233.
} 
se jednalo již o 3900000 obyvatel. ${ }^{304}$ Podle oficiálních údajů z roku 2000 žilo v tomto roce v Tádžické republice přibližně 5762300 obyvatel tádžické národnosti. ${ }^{305} \mathrm{~V}$ roce 2014 žilo v této středoasijské republice již 8 milionů obyvatel (z toho cca 80 \% tádžické národnosti). ${ }^{306}$ Tyto údaje jsou uvedeny pouze jako jisté doplnění problematiky, nelze je však považovat za naprosto relevantní a nekriticky z nich vycházet při dalším zpracovávání dané problematiky.

Důvodem této určité nerelevantnosti je jednak skutečnost, že se jedná o data získaná z různých zdrojů a není tedy úplně jisté, zda dané údaje popisují vždy to samé. ${ }^{307}$ Další problematizující skutečností je fakt, že některé skupiny žijící v Tádžické republice jsou tádžickou legislativou považovány za Tádžiky, nikoliv za příslušníky etnických minorit, přestože se od tádžického etnika odlišují jazykem a mnohdy i náboženstvím. Skutečnost, že příslušníci těchto skupin jsou oficiálně registrováni jako Tádžici (národnost tádžická), ovšem neznamená, že je tádžičtina jejich primárním jazykem. ${ }^{308} \mathrm{~V}$ tomto prípadě je tedy třeba rozlišovat mezi oficiálně připsanou národností (například při sčítání obyvatelstva) a jazykovou příslušností. Tato skutečnost se týká především příslušníků pamírských skupin, jejichž národnost je sice oficiálně tádžická, přesto se jimi užívané jazyky od tádžičtiny výrazně odlišují.

Tádžičtina, podobně jako jazyky pamírské (či jaghnóbština atd.) se řadí do indoevropské jazykové rodiny, čímž se podstatně liší od jazyků turkických (kyrgyzština, uzbečtina, kazaština atd.), které jsou řazeny

\footnotetext{
304 Baar 2002.

305 Ministerstvo zahraničních věcí ČR. In: www.mzv.cz [cit. 2009-06-02].

306 Ministerstvo zahraničních věcí ČR. In: www.mzv.cz [cit. 2015-09-05].

307 Problematiku určité nejednoznačnosti výsledků jednotlivých cenzů obyvatelstva zmiňuje např́klad Leoš Šatava ve své knize Národnostní menšiny v Evropě (Šatava 1994).

308 Jedná se především o Pamírce. Například jedna šugnánská informantka autorovi v průběhu léta 2015 popisovala náležitosti pro získání cestovního pasu - vyplňuje národnost tádžickou (přestože se cítí být Pamírkou - Šugnánkou). Tato skutečnost se vztahuje jak k pasu vnitřnímu (obdoba českého občanského průkazu) tak k pasu mezinárodnímu. Retka 2015.
} 
do jazykové rodiny altajské. Z hlediska další klasifikace je tádžičtina součástí následujícího schématu: ${ }^{309}$

Indoevropská jazyková rodina $\rightarrow$ indoíránská větev $\rightarrow$ iránské jazyky $\rightarrow$ západní íránské jazyky $\rightarrow$ jihozápadní iránské jazyky $\rightarrow$ perské jazyky. ${ }^{310}$

Současná tádžičtina je velice blízká iránské fársí i afghánské dárí, tyto jazyky jsou vzájemně srozumitelné. Oproti dárí a fársí však tádžičtina obsahuje kromě jazykových výpưjček z arabštiny výpưjčky i z uzbečtiny a ruštiny. ${ }^{311}$

Tádžičtina se dělí do čty̌r základních dialektických skupin. ${ }^{312}$

\section{Severní skupina dialektů}

- samarkandsko-bucharský dialekt - základ dnešní spisovné tádžičtiny

- západoferganský dialekt

- východoferganský dialekt

- uratjubinský dialekt

- pendžikentský dialekt

- varzobsko-gissarský dialekt

Centrální skupina dialektů

- matčinský dialekt

- falgarský dialekt

Jižní skupina dialektů

- vachánsko-karateginský dialekt

- kuljabský (severní, jižní a západní) dialekt

- kuljabsko-gissarský dialekt

- rogský dialekt

- badachšánský dialekt

309 Kokaisl 2007, 218-233.

310 Gordon, Raymond G., Jr. (ed.). Dostupný z www.ethnologue.com/show_country. asp?name=TJ [cit. 2006-12-16].

311 Rahmonová 2011.

312 Kokaisl 2007, 218-233. 


\section{Jihovýchodní skupina dialektů}

- darvazský dialekt

- vančský dialekt

Nargis Rahmonová upozorňuje, že jednotlivé dialekty tádžičtiny si jsou velice blízké a výrazněji se od sebe neodlišují. Jisté rozdíly jsou však patrné v rovině jazykových výpůjček z jiných jazykových systémů. Jižní dialekty tádžičtiny jsou ovlivněné především afghánskou dárí, oproti tomu v severních dialektech je patrnější vliv turkické uzbečtiny. ${ }^{313}$

\section{Psaný projev tádžického jazyka}

„Pokud jde o psaný projev, docházelo v průběhu dvacátého století k velkým proměnám - od arabského písma, když se dané jazyky konstituovaly, pres latinku ve dvacátých letech a posléze i cyrilici zavedenou sovětským režimem, po dnešní stav, kdy se některé státy pokusily s různým úspěchem znovu o změnu na turkizovanou latinku. “314

Fenomén návratu k turkické verzi latinky se ovšem netýká psané formy tádžičtiny. Pủvodní písmo, které obyvatelé oblasti dnešní Tádžické republiky použivali, bylo arabské, to však bylo v roce 1930 nahrazeno latinkou ${ }^{315}$ a po roce 1940 byla ustanovena ruská azbuka. ${ }^{316} \mathrm{Na}$ počátku devadesátých let se objevily určité snahy některých opozičních skupin transformovat tádžický jazyk na arabsko-perský systém písma. Tyto pokusy 0 zásadní změnu psané formy tádžického jazyka se ovšem nezdařily a tak je azbuka v Tádžikistánu použivána i nadále. Zajímavý moment nastal v průběhu príprav ratifikace mírové smlouvy o ukončení tádžické občanské války. Zatímco prezident Emómalim Rahmón

\footnotetext{
313 Rahmonová 2011.

314 Horák 2008, 15.

315 Přechod neruských populací na latinskou verzi abecedy připravoval na počátku dvacátých let dvacátého století Lidový komisariát pro národnostní otázku. Tato instituce, v jejímž čele stál v letech 1917 až 1923 Stalin, měla za úkol koordinovat vztahy mezi centrem a neruskými oblastmi SSSR. Jedním z úkolů byla př́prava přechodu neruských populací na latinské písmo. Bahenský 2010, 7-24.

316 Kokaisl 2007, 218-233.
} 


\begin{tabular}{|c|c|c|c|c|c|c|}
\hline \multicolumn{2}{|c|}{$\begin{array}{c}\text { Печапные } \\
\text { буювы }\end{array}$} & \multirow{2}{*}{$\begin{array}{c}\begin{array}{c}\text { Рукописные } \\
\text { буквы }\end{array} \\
A a\end{array}$} & $\begin{array}{c}\text { Названия } \\
\text { буюв }\end{array}$ & $\begin{array}{c}\text { Печапньюе } \\
\text { буювы }\end{array}$ & \multirow{2}{*}{\begin{tabular}{|c|}
$\begin{array}{c}\text { Рукописнье } \\
\text { буювы }\end{array}$ \\
$y y$
\end{tabular}} & \multirow{3}{*}{$\begin{array}{l}\begin{array}{c}\text { Названия } \\
\text { буюв }\end{array} \\
\mathrm{y} \\
\text { эф }\end{array}$} \\
\hline A & a & & a & $\mathrm{y} y$ & & \\
\hline B & 6 & $\mathscr{D} \cdot \delta$ & 69 & $\Phi \phi$ & $\not \partial \phi$ & \\
\hline B & B & 96 & B9 & $\mathrm{X} x$ & $\mathscr{T} x$ & $\mathrm{xa}$ \\
\hline$\Gamma$ & $\Gamma$ & $\mathscr{T}_{2}$ & rэ & I & $\mathscr{Q} 4$ & ц9 \\
\hline д & д & (2) $q$ & дэ & 44 & य $t$ & 49 \\
\hline E & e & $8 e$ & e & Ш & $\mathscr{U} u$ & ша \\
\hline $\mathrm{E}$ & $\ddot{\mathbf{e}}$ & $\delta e$ & è & щ & $\mathscr{W l}_{u_{0}}$ & ma \\
\hline Ж & ж & $\mathscr{M} \varkappa$ & жэ & b & $8 x$ & $\begin{array}{c}\text { аломати } \\
\text { сакта }\end{array}$ \\
\hline 3 & 3 & $33^{3}$ & 39 & bl & $b t a$ & еры \\
\hline И & и & $\mathscr{U}_{u}$ & и & b b & 60 & $\begin{array}{l}\text { аломати } \\
\text { ңудой }\end{array}$ \\
\hline$\ddot{n}$ & म̆ & $\ddot{\mathscr{U}} \ddot{u}$ & и-и кӱғох & $9 \theta$ & 93 & 3 \\
\hline $\mathbf{K}$ & K & $\mathscr{K} \kappa$ & ка & K & $10 \%$ & 10 \\
\hline$\pi$ & $\pi$ & $\mathscr{A}$ & FII & Я Я & 92 & я \\
\hline$M$ & $M$ & $\mathscr{U} u$ & $9 \mathrm{M}$ & F $\quad F$ & $F_{z}$ & F9 \\
\hline $\mathrm{H}$ & H & $\mathscr{H}_{*}$ & эн & ด หั & $\mathscr{U}$ & $\begin{array}{l}\text { и-и за- } \\
\text { данок }\end{array}$ \\
\hline 0 & 0 & 00 & 0 & K K & $\mathscr{L} \backsim$ & қэ \\
\hline$\Pi$ & $\Pi$ & $\mathscr{\mathscr { T }} n$ & no & $\bar{y} \bar{y}$ & $\bar{y}$ & $\hat{y}$ \\
\hline $\mathrm{p}$ & $\mathrm{p}$ & 90 & sp & $\mathrm{X} x$ & $x_{1} x_{i}$ & x9 \\
\hline C & c & $C c$ & $x$ & પ્ મ્ & $\psi$ & 49 \\
\hline$T$ & $T$ & $\mathscr{M} m$ & TЭ & & & \\
\hline
\end{tabular}

Obrázek č. 1. Tádžická abeceda.

Dostupné z http://www.primavista.ru/dictionary/abc/tajik.htm

podepsal smlouvu psanou azbukou, představitel opozice Saíd Abdulló Núrím ratifikoval verzi smlouvy napsanou arabským písmem. ${ }^{317}$

317 Horák 2008. 
Tádžická azbuka se však od té ruské v některých dílčích aspektech odlišuje. Na tuto skutečnost upozornil jeden z tádžických informantů, který upozornil na skutečnost, že Tádžikové ve svém psaném projevu (v tádžické verzi azbuky) disponují navíc čtyřmi znaky - písmeny, pro které nemá ruská azbuka odpovídající ekvivalenty. Podle tohoto informanta tyto tádžické specifické znaky príbližně odpovídají slabikám dže, he, ee/eo a kh.318

\section{Pamírské jazyky}

Dalši výraznou jazykovou skupinu, která je v Tádžické republice zastoupena, představují již zmíněné pamírské jazyky. Jak již bylo uvedeno v predchozím textu, stejně jako tádžičtina, i jazyky pamírské patří do indoevropské jazykové rodiny, indoíránské větve a do skupiny íránských jazyků. Od tádžičtiny se však pamírské jazyky odlišují skutečností, že se nejedná o jazyky západoíránské, nýbrž východoíránské. Z hlediska jazykové klasifikace jsou pamírské jazyky součástí následujícího schématu: ${ }^{319}$

Indoevropská jazyková rodina $\rightarrow$ indoíránská větev $\rightarrow$ iránské jazyky $\rightarrow$ východní íránské jazyky $\rightarrow$ jihovýchodní íránské jazyky $\rightarrow$ pamírské jazyky.

\section{Členění pamírských jazyků}

Je vhodné upozornit na skutečnost, že tato část textu se primárně zaměřuje především na lingvistickou situaci v Tádžikistánu - konkrétně v Autonomní oblasti Horského Badachšánu. ${ }^{320}$ Uživatelé pamírských

318 Retka 2006, Ukázka tádžické abecedy - Příloha č.1.

${ }^{319}$ Gordon, Raymond G., Jr. (ed.). Dostupný z www.ethnologue.com/show_country. asp?name=TJ [cit. 2006-12-16].

320 Tato autonomní oblast je integrální součástí Tádžikistánu již od roku 1924. Rozkládá se ve východní polovině Tádžické republiky. Používá se pro ní zkratka GBA0, tedy Gorno-Badakhshanskaya Avtonomnaya Oblast, přičemž termín Gorno- odkazuje na horský charakter lokality. Tento konkretizující údaj umožnil sovětskému aparátu vymezit se vưči pamírským (vachánským) oblastem nacházejícím se v afghánském Badachšánu. Kreutzmann 2015, 351-430. Více o sovětské strategií zakládání tzv. konkurenčních autonomních jednotek jakožto ideových konkurentů k sousedním 
jazyků však nežijí pouze v tádžické GBA0, ale také na území států sousedních (Afghánistán, Čína - Ujgurstán) popřípadě ve státech geograficky nepř́liš vzdálených (Pákistán). ${ }^{321}$

Z hlediska problematiky dalšího členění skupiny pamírských jazyků zastávají jednotliví autoři, kteří se danou otázkou zabývají, mnohdy rozdílné postoje.

Slavomír Horák poukazuje na základní dělení pamírských jazyků. Podle tohoto přístupu patří mezi pamírské jazyky (v případě Horáka mezi jazyky Horského Badachšánu):

- $\quad$ iškašemský jazyk

- vachánský jazyk

- Šugnánsko-rušánský jazyk (a jeho dialekty)

- jazgulámský jazyk (viz předchozí text - specifická skupina na pomezí Pamírců a Tádžiků)

Kromě těchto čtyř základních pamírských jazyků patří mezi „tádžické” východoíránské jazyky i již zmiňovaná jaghnóbština. ${ }^{322}$ Jaghnóbský jazyk se však od jazyků pamírských liší v dílčím aspektu, zatímco jazyky pamírské jsou íránské jihovýchodní, jaghnóbština 323 je řazena do skupiny íránských jazyků severovýchodních. ${ }^{324}$ S podobným schématem členění pamírských jazyků, které použivá Slavomír Horák, se lze setkat i na internetových stránkách serveru www.ethnologue.com. ${ }^{325}$

Podle jiného způsobu schématizace Ize pamírské jazyky dělit na jazyk šugnánský (a jeho rušánský a badžuvský dialekt), bartángský, sarikolský, jazgulámský, vančský - starovančský (mrtvý jazyk), vachánský

státům (například sovětský Turkmenistán x Turecko, sovětské Karelofinsko x Finsko atd.) Bahenský 2010, 7-24.

${ }^{321}$ Gordon, Raymond G., Jr. (ed.). Dostupný z www.ethnologue.com/show_country. asp?name=TJ [cit. 2006-12-16].

322 Horák 2005.

323 Více k jaghnóbštině viz Novák 2010.

324 Gordon, Raymond G., Jr. (ed.). Dostupný z www.ethnologue.com/show_language. asp?code=yai [cit. 2006-12-16].

${ }^{325}$ Gordon, Raymond G., Jr. (ed.). Dostupný z www.ethnologue.com/show_country. asp?name=TJ [cit. 2006-12-16]. 
a iškašiský. ${ }^{326}$ Při studiu jiných zdrojů informací se lze setkat i s názvy jazyků doposud neuvedených. Např́iklad podle publikace Tádžická SSR se pamírské jazyky dělí na šugnánsko-rušánské (a jejich dialekty), jazgulemské, iškašimské, vachánské a mundžanské. ${ }^{327}$

\section{Početní zastoupení jednotlivých pamírských jazyků}

Z pamírských jazyků je nejpočetněji zastoupena šugnánština. V roce 1975 hovořilo tímto pamírským jazykem $20000^{328}$ obyvatel GBA0, k tomuto údaji je však třeba pripočíst približně 2000 obyvatel, kteří používali orošorský dialekt šugnánštiny, a 15000 obyvatel hovoříích dialektem rušánským. ${ }^{329} \mathrm{~V}$ roce 1989 se jednalo 070000 obyvatel GBA0 (není uvedeno, zda včetně dialektů - nejspíše ano). V průběhu sčitání obyvatelstva v roce 1988 bylo zjjštěno, že tímto jazykem hovořilo príbližně 18000 z celkového počtu 20154 obyvatel Chorogu (správní město GBA0). ${ }^{330}$ Podle jiných zdrojů informací v roce 1997 používalo šugnánský jazyk více než 100000 obyvatel Tádžikistánu (především GBA0) a přibližně 50000 obyvatel Islámské republiky Afghánistán. ${ }^{331}$

Ostatní pamírské jazyky jsou zastoupeny o poznání méně. K vachánskému jazyku se hlásí přibližně 7000 obyvatel Tádžikistánu (dále 9000 Vachánců žije v Pákistánu, 7000 v Afghánistánu a 6000 v Číně). ${ }^{332}$ Bartánský jazyk byl v roce 1932 zastoupen přibližně 2000 mluvčími, $v$ roce 1959 se jednalo o 1000 obyvatel GBAO a v devadesátých letech (1997) o 2500 osob. Jazgulámský jazyk použivá přibližně 4000 mluvčích a iškašimsky hovoří približně 500 obyvatel jižní části GBAO (přibližně 2000 Iškašimců žije v Afghánistánu). ${ }^{333}$

\footnotetext{
326 Mamadšerzodšejev 2007.

327 Kokaisl 2007, 218-233.

328 Různé zdroje často uvádějí rozdílné počty. Záleží, co konkrétně popisují (mateřský jazyk, každodenní užívání atd.) viz Šatava 1994.

${ }^{329}$ Gordon, Raymond G., Jr. (ed.) www.ethnologue.com/show_language. asp?code=sgh, [cit.2009-06-14], srovnej Bliss 2006.

330 Alamojev 2007.

331 Mamadšerzodšejev 2007.

332 Čínští Pamírci (Vachánci) bývají označování za tzv. Sarikoli - viz informace z roku 2014 od lingvisty Shodichona Jusufbekova. Retka 2014.

333 Mamadšerzodšejev 2007.
} 
Zajímavý jazykový fenomén představuje oblast lškašimského rajonu GBA0. Jeden z pamírských informantü ${ }^{334}$ uvedl, že se $v$ této oblasti mluví především vachánsky, rínsky a goronsky (jazyk podobný tádžičtině). Podle jiného informanta ${ }^{335}$ se v lškašimském rajonu hovoří vachánsky, tádžicky, rínsky (pouze jedna vesnice ${ }^{336}$ - s ostatními komunikují tádžicky) a jazykem fársí. Mamadšerzodšejev upozorňuje na skutečnost, že v lškašimském rajonu GBAO hovoří iškašimsky pouze 500 obyvatel žjijicích ve vesnicích Nud, Sumdžin a Mulvodž. ${ }^{337}$ Lingvista Davlatbekov rozšrir̃ení jednotlivých jazyků v lškašimském rajonu vymezil v prüběhu společné konzultace i geograficky. Od vesnice Šochorog (na hranici mezi Šugnánským a lškašimským rajonem) na jih, až po centrum Iškašim používají Pamírci především tádžičtinu. Od Iškašimi na východ prevládá vachánština. ${ }^{338}$

Na základě výše uvedených informací je možné konstatovat, že otázka členění a vymezování početního zastoupení jednotlivých pamírských jazyků představuje problematiku poměrně složitou. Při zpracovávání tohoto tématu je potřeba vycházet ze skutečnosti, že data uvedená $\checkmark$ jednotlivých zdrojích informací se mohou od sebe značně odlišovat. Důvodem této situace je mimo jiné i poměrně vysoký počet dialektů jednotlivých jazykůu, které ovšem nejsou všemi autory zohledňovány a do celkových součtů mluvčích započitávány. $K$ výše uvedeným počtưm mluvčích jednotlivých jazyků je tedy třeba přistupovat „pouze orientačně" a potenciálně počítat s dílčími odchylkami v celkových počtech osob, které daný jazyk používají.

\footnotetext{
334 Retka 2013.

335 Retka 2006.

336 Jedná se nejspíše o vesnici Rín vzdálenou cca 2 km východně od města lškašim. Ve vesnici Rín hovoří obyvatelé tzv. rínským jazykem, někdy je označován za jazyk iškašimský (většina obyvatel města lškašim však používá jazyk tádžický). Retka 2013. 337 Mamadšerzodšejev 2007.

338 Retka 2015.
} 


\section{a ā в c ç $\in$ d đ e a f g oI g h i i j k l m \\ n o e p q r s ş $\mathrm{t}$ b u u v w x * z z 3}

Obrázek č. 2. Šugnánská abeceda - latinská verze (1931).

Dostupné z https://gl.wikipedia.org/wiki/Lingua_xugn\%C3\%AD

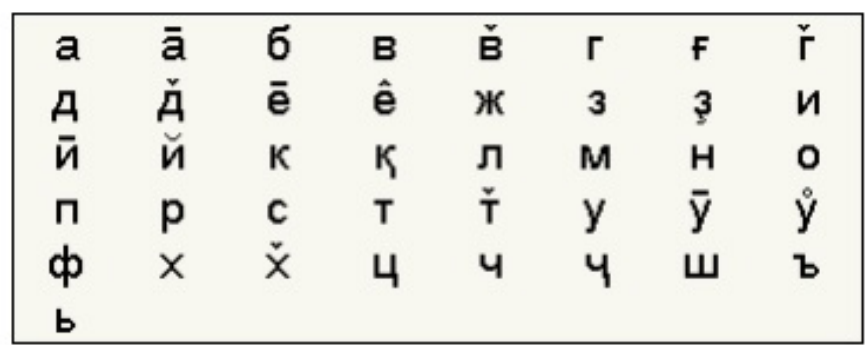

Obrázek č. 3. Šugnánská abeceda - azbuka (1938).

Dostupné z https://gl.wikipedia.org/wiki/Lingua_xugn\%C3\%AD

\section{Problematika psaného projevu pamírských jazyků}

Problematiku pamírských jazyků je možné doplnit i o otázku psaného projevu. Většina z těchto jazyků v současné době nemá vytvořený kodifikovaný systém znaků (abecedu), jehož prostřednictvím by bylo možné orální verzi jazyka písemně zaznamenat. Jako literární jazyk je většinou používána tádžičtina. ${ }^{339}$ Výjimkou je jazyk šugnánský, který disponuje vlastní abecedou. Kodifikovaná šugnánština byla zpracována i do podoby rusko-šugnánského slovníku. ${ }^{340}$ Kodifikovaná šugnánská abeceda představuje poměrně zajímavý fenomén mezi pamírskými jazyky. Nejedná se pouze o skutečnost, že šugnánština je jediný psaný pamírský jazyk (alespoň co se týče Tádžikistánu), ale také o to, že se jedná o systém, který má dvě základní varianty. Jedná se o šugnánskou verzi

339 Grimes, F. Barbara (ed.). Dostupný z www.christusrex.org/www3/ethno/Taji.html [cit. 2006-12-16]. Podobná situace je podle Rahmonové i u „nepamírských“ Jaghnóbců. Podle této autorky jsou Jaghnóbci často bilingvní a tádžičtinu používají především v rovině psaného projevu. Rahmonová 2011.

340 Karamšojev 2005. 
azbuky a o šugnánskou verzi latinky. Dochází tedy k určité nejednotnosti, jakým směrem se šugnánština bude v rámci určitých etnoemancipačních snah dále ubírat. Již v minulosti se objevovaly různé přístupy k zápisu šugnánštiny. Významný ruský autor Zarubin např́klad sepsal svůj rusko-šugnánský slovník v latince (tedy jen šugnánskou část, ruskou psal samožrejmě v azbuce). ${ }^{341}$ Oproti tomu výše zmiňovaný šugnánský lingvista Karamšoev sepsal svůj šugnánsko-ruský slovník celý v azbuce. Na základě svého výzkumného působení v letech 2014 a 2015 může autor tohoto textu konstatovat, že tato nejednotnost přetrvává až dodnes. Zatímco na Institutu humanitních věd v Chorogu spíše převládá postoj zapisovat šugnánštinu latinkou, vzdělávací organizace Nur vydává své publikace (knihy pro děti) především psané azbukou. ${ }^{342}$

Před př́chodem „arabské civilizace” do regionu Střední Asie užívali obyvatelé Pamíru vlastní písmo, jehož podoba se do dnešní doby nezachovala. Společně s konverzí k islámu přešli obyvatelé Pamíru na arabskou abecedu, která se stala v devatenáctém století základem pro „vlastní" šugnánské písmo (šugnánská verze arabské abecedy). V třicátých letech dvacátého století byl šugnánský jazyk přetransformován na písmo latinské a později byla pro potřeby psaného projevu zavedena ruská azbuka (její šugnánská verze). ${ }^{343}$

Podobně jako v prípadě tádžičtiny, tak i v souvislosti s pamírskými jazyky (konkrétně se šugnánštinou), upozorňovali informanti na skutečnost, že „jejich“ abeceda se od té ruské, ale i od tádžické, v jistých dílčích aspektech odlišuje. Jeden z pamírských informantư ${ }^{344}$ poukazoval na skutečnost, že nejen tádžická verze azbuky se od té ruské liší (čtyři odlišné znaky - viz předchozí text), ale že i šugnánština disponuje dvěma znaky, pro které nemá adekvátní ekvivalenty nejen ruština, ale ani tádžičtina. Konkrétně se jedná o znaky sloužící k záznamu slabik žše a re. ${ }^{345}$

\footnotetext{
341 Zarubin 1960.

342 Retka 2014 a 2015.

${ }^{343}$ Mamadšerzodšejev 2007.

344 Retka 2006.

${ }^{345}$ Retka 2006. Šugnánská verze latinské abecedy - Příloha 2 a šugnánská verze azbuky - Př́loha 3.
} 


\section{Závěr}

Jazyková situace v dnešní Tádžické republice tedy představuje poměrně složité a obsáhlé téma. Jedná se o fenomén, který může zásadním způsobem ovlivňovat snahy centra o sjednocování a udržování konceptu jednotného tádžického národa, který v oficiální rovině zahrnuje nejen mluvčí tádžičctiny, ale i príslušníky ostatní indoíránských skupin (byt ti se s tímto konceptem často neztotožňují). Etnoemancipační snahy těchto minoritních skupin mohou být $v$ budoucnu vedeny především v rovině jazykové svébytnosti.

Především v důsledku sovětské národnostní politiky vznikla na území Tádžikistánu jazyková situace, která svým charakterem a dynamikou neoslovuje v akademické rovině „pouze“ lingvisty, ale také antropology, politology a další sociální vědce. 


\section{Literatura}

Alamojev, M. M. 1994. Sistema mestoimenij šugnanskogo jazyka. Dušanbe.

Baar, Vladimír. 2002. Národy na prahu 21. století - emancipace nebo nacionalismus? Šenov u Ostravy: Ostravská univerzita.

Barth, Fredrik. 1969. „Introduction.” In Ethnic Groups and Boundaries: The Social Organization of Culture Differences, vyd. Frederik Barth, 9-38. Bergen: Universitets Forlaget.

Bliss, Frank. 2006. Social and Economic Change in the Pamirs (Gorno Badakhshan, Tajikistan). London - New York: Routledge.

Bromlej, Julian Vladimirovič. 1980. Etnos a etnografia. Bratislava: Veda.

Constitution of the Republic of Tajikistan. Dostupné z http://www. refworld.org/pdfid/3ae6b50910.pdf_[cit. 2016-04-15].

Eriksen, Thomas Hylland. 2007. Antropologie multikulturních společností: Rozumět identitě. Praha: Triton.

Gordon, Raymond G., Jr. (ed.). Dostupné z www.ethnologue.com/ show_country.asp?name=TJ [cit. 2009-06-10].

Grimes, F. Barbara (vyd.). Dostupné z www.christusrex.org/www3/ ethno/Taji.html [cit. 2006-12-16].

Horák, Slavomír. 2005. Střední Asie mezi Východem a Západem. Praha: Karolinum.

Horák, Slavomír. 2008. Rusko a Střední Asie po rozpadu SSSR. Praha: Karolinum.

Karamšojev, Dodchudo. 2005a. Russko-šugnanskij slovar (4. svazek). Dušanbe.

Karamšojev, Dodchudo. 2005b. Slovar pamirskich ličnych imen (5. svazek). Dušanbe.

Kokaisl, Petr, Jan Pargač a kol. 2007. Lidé z hor a pouští: Tádžikistán a Turkmenistán - Stř́pky kulturních proměn Střední Asie. Praha: Univerzita Karlova, Filozofická fakulta. 
Kreutzmann, Hermann. 2015. Pamirian Crossroads. Wiesbaden.

Mamadšerzodšejev, Ymed, Džonbobojev Šozodamamadovič, Džonbobojevič Nazardod a Jaminovna Jaminova Mavzuna. 2007. Pamir: priroda, istorija, kultura. Biškek.

Marek, Jan. 2006. Dějiny Afghánistánu. Praha: Lidové noviny.

Ministerstvo zahraničí České republiky - Tádžikistán. Dostupné z http://www.mzv.cz/jnp/cz/encyklopedie_statu/asie/tadzikistan/index.html [cit. 2015-09-05].

Novák, Lubomír. 2010. Jaghnóbsko-český slovník. Praha: Univerzita Karlova, Filozofická fakulta.

Pollock, John M. 2001. Ahmad Shah Massoud: A case study in the challenges of leading modern Afghanistan. Quantico, Virginia: Marine Corps Combat Development Command. Dostupné z http://www. dtic.mil/dtic/tr/fulltext/u2/a407559.pdf [cit. 2015-09-05].

Rahmonová, Nargis. 2011. „Jazyková situácia v stredoázijských republikách bývalého ZSSR." Jazyk a kultúra 8/2011.

Retka, Tomášs. 2010. "Identita(y) obyvatel tádžického Pamíru." AntropoWEBZIN, 253-261.

Smith, Anthony, D. 2003. „Etnický základ národní identity.” In Pohledy na národ a nacionalismus - čítanka textů, vyd. Miroslav Hroch, 270-296. Praha: Sociologické nakladatelství.

Šatava, Leoš. 1994. Národnostní menšiny v Evropě. Praha: Ivo Železný. Šlachta, Mojmír. 2007. Ohniska napětí ve světě. Praha: Kartografie.

Wolf, Paul. 2003. The Assassination of Ahmad Shah Massoud. Dostupné z http://www.ratical.org/ratville/CAH/ASMassoud.pdf [cit. 2015-09-05].

Zarubin, Ivan Ivaničevič. 1960. Shughnanskie teksty i slovar. Moskva: Izdatel'stvo Akademii nauk SSSR. 


\section{Summary}

The main goal of this volume is to describe the history and culture of civilizations which developed on an extensive territory, including the Near East as well as some territories in Central and South Asia. Experts from various scientific institutions in the Czech Republic as well as in Slovakia who have long been involved in the study of the cultures on this territory present here the results of their research projects which are devoted to various aspects of the historical development. The main topic of the majority of the projects is the study of the cultures of Asia in the antiquity, but also some problems connected with the present developments are mentioned as well.

Pavel Král in his paper describes the development of settlement patterns in the area of Mosul in northern Mesopotamia in the Early Bronze period. Also the contribution by Kateřina Šašková is related to the history of ancient Mesopotamia. The author thouroughly studies the written sources that mention the treatment of the illness from which the Assyrian king Asarhaddon (680-669 B.C.) suffered. Michal Habaj evaluates a wide range of written sources pertaining to the history of Scythians and tries to reconstruct the ways in which that ethnic group is portrayed in the classical historiographic work by Herodotus. On the other hand, the paper presented by David Rafael Moulis is based primarily on the archaeological data. Its main goal is to reconstruct the ritual offerings that were deposited under the floor of various buildings in order to protect those buildings as well as their 
inhabitants. Other papers are devoted to more recent topics. Katarína Šomodiová studies the contemporary communities of Mandaeans in Khuzistan (Iran) as well as in some European countries (Germany and Denmark). The contribution by Simona Levá Jandová leads us to the region of Southern India and describes the traditional Tamil tales called Kuravanji. The region of Central Asia is represented by the study performed by Tomáš Retka who analyzes the linguistic situation in the contemporary Republic of Tajikistan.

The texts of the individual papers were presented at the 16th colloquium Orientalia Antiqua Nova which was organized by the Department of Middle East Studies of the Faculty of Philosophy and Arts of the University of West Bohemia in Pilsen in April 2016. We believe that the present publication will be useful to the wide scientific public which is interested in the development of civilizations in Asia.

Lukáš Pecha the editor 